$$
\begin{aligned}
& \text { HEDL-TME- 79-17 } \\
& \text { UC-41, 79a }
\end{aligned}
$$

\title{
LIQUID METALS FIRE CONTROL ENGINEERING HANDBOOK
}

\author{
Compiled by J.I. Ballif \\ Ford, Bacon \& Davis Utah Inc.
}

\author{
Prepared For \\ WESTINGHOUSE HANFORD OPERATING \\ THE HANFORD ENGINEERING DEVELOPMENT LABORATORY
}

And The

UNITED STATES DEPARTMENT OF ENERGY

ASSISTANT SECRETARY FOR ENVIRONIENT.

DIVISION OF OPERATIONAL AND ENVIRONMENT SAFFTY

\section{February 1979}

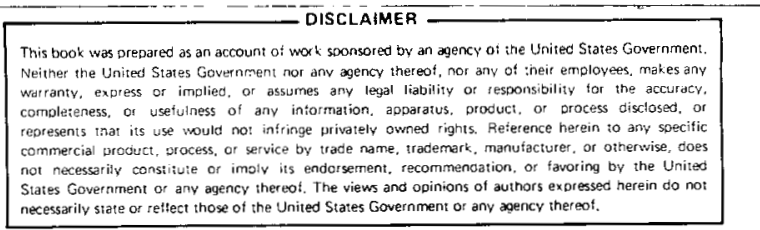

PUBLICLY RELEASABLE

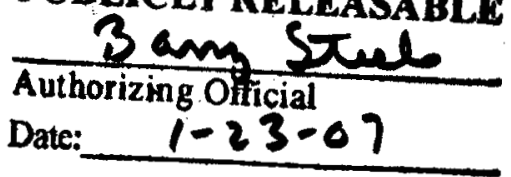




\section{DISCLAIMER}

This report was prepared as an account of work sponsored by an agency of the United States Government. Neither the United States Government nor any agency Thereof, nor any of their employees, makes any warranty, express or implied, or assumes any legal liability or responsibility for the accuracy, completeness, or usefulness of any information, apparatus, product, or process disclosed, or represents that its use would not infringe privately owned rights. Reference herein to any specific commercial product, process, or service by trade name, trademark, manufacturer, or otherwise does not necessarily constitute or imply its endorsement, recommendation, or favoring by the United States Government or any agency thereof. The views and opinions of authors expressed herein do not necessarily state or reflect those of the United States Government or any agency thereof. 


\section{DISCLAIMER}

Portions of this document may be illegible in electronic image products. Images are produced from the best available original document. 


\section{ABSTRACT}

This handbook reviews the basic requirements of the use of liquid metals with emphasis on sodium which has the greatest current usage. It delineates the concepts necessary to design facilities both radioactive and nonradioactive for use with Iiquid metals. It further reviews the state-ofthe-art in fire extinguishers and leak detection equipment and comments on their application and sensitivity. It also provides details on some engineering features of value to the designer of liquid metal facilities. 
Abstract . . . . . . . . . . . . . . List of figures .............. iv INTRODUCTION . . . . . . . . . . . . . 1

1. THE NATURE OF LIQUID METALS .......... 2

1.1 What are They .............. 3

1.2 Why are They Used . . . . . . . . . . . 3

1.3 Characteristics of Liquid Metals . . . . 5

2. CHEMICAL AND PHYSICAL PROPERTIES OF SODIUM . . . 16

3. THE BURNING OF SODIUM . . . . . . . . 20

4. BASIC CONCERNS IN THE USE OF LIQUID METAL • • . 26

4.1 Containment . . . . . . . . . . . 26

4.2 Change from Solid to Liquid Phase... . . 26

4.3 Inert Atmospheres . . . . . . . . . . . 27

4.4 Wetability of surfaces ......... 28

4.5 Removal of Liquid Metals from Components . . 28

5. SYSTEM CONSIDERATIONS ............ 40

5.1 Codes and standard ............ 40

5.2 Isolation of Liquid Metal zones .......4 41

5.3 Sodium System Rigs ........... 41

5.3 .1 Isolation ............ . 4I

5.3.2 Compartmentation .......... 42

5.3.3 Non-Water Fire Control . . . . . . 43

5.3.4 Liquid Metal Catch Pans . . . . . . 43

5.3.5 Fire Detection Depends on Instruments 45

5.3.6 Instrumentation and Control

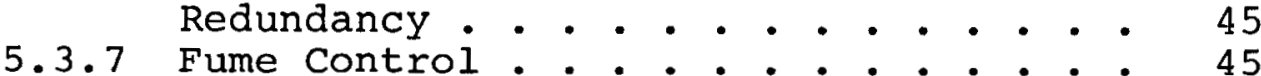

6. APPLICATION OF PRINCIPLES TO REACTOR SYSTEMS . . 55

6.1 Radioactive Systems . . . . . . . . 55

6.2 Nuclear Reactor Design Considerations . . . 55

6.3 Compartment Inerting . . . . . . . . . 56

6.4 Fume Handling and Ventilation ....... . 57

6.5 Fire Extinguishing Agents ....... 58

6.5.1 Philosophy of Extinguishment Techniques ........... 58 
6.5.2 Estimating the Quantity of Liquid Metal Leaked ........... 59

6.5 .3 Extinguishing of Smali fires . . . . 59

6.5.4 Extinguishing of Large Fires... . 59

6.6 Fire Protection Methods Used in Present

Facilities ............ 60

6.6 .1 Solid Powders .......... 60

6.6 .2 Inert Gas ............ 62

6.6.3 Other Extinguishment Methods.... 63

6.7 Testing of Extinguishment Methods . . . . 64

6.7 .1 Background ............ 64

6.7 .2 Testing Before 1970 ....... 65

6.7 .3 Current Testing 1971 to 1978 .... 66

6.8 Insulation . . . . . . . . . . 67

6.9 Leak Detection . . . . . . . . . . 95

6.9.1 Background ............ 95

6.9 .2 State of the Art . . . . . . . . 95

6.9.3 Description of Existing Types of

Detectors . . . . . . . . 97

Liquid Sodium Detectors . . . . . 97

Sodium Vapor Detectors . . . . . . 99

Chemical Detectors . . . . . . 103

Radiation Detectors ....... 107

Smoke Detectors .......... 108

Hydrogen Detectors ......... 110

Thermal Detectors . . . . . . . 112

Specific Chemical Detectors'. . . 112

Infra-Red \& Ultra-Violet Detectors . . 113

Solid State Detectors . . . . . 113

Miscellaneous Detectors . . . . . 113

6.10 Codes and Calculations ......... 114

6.11 Details of Engineered Features of Contain-

ment System ............. 116

6.11 .1 Penetration of Piping and Power/

Control Lines . . . . . . . . 117

6.11.2 Trenches, Curbs and celis ..... 117

6.11 .3 Compartmentation ........ 118

6.12 Miscellaneous Items . . . . . . . . 118

6.12.1 Sodium Protective Suit . . . . . . 118

6.12.2 General Protective Gear for Sodium
Handling............ 120 
6.12.3 First Aid for Liquid Metal Burns . . 121

6.12.4 Oxygen Deficient Atmospheres . • . . 121

6.12 .5 Handling and Storage of Liquid Metals . . . . ..... 121

6.12.6 Disposal of Liquid Metals .... 123

7. EXPERIENCE IN MAJOR REACTORS USING LIQUID METALS • 145

8. BIBLIOGRAPHY . . . . . . . . . . . 148 


\section{LIST OF FIGURES}

Nuinber

Page

L Reasons for Using Sodium. . . . . . . . . . 6

? Problems Related to Sodium. . . . . . . . . . 7

3 Properties of Inert Gas . . . . . . . . . . 8

it How To Fight Sodium Fires . . . . . . . . . . . 9

5 Physical Properties of Sodium . . . . . . . . . 10

is Physical Properties of Sodium . . . . . . . . 11

7 Radiological Implications on Design . . . . . . 12

i3 Radiological Implications on Design . . . . . . 13

7 Radiological Implications in Sodium . . . . . . . 14

1) Combustion of Sodium. . . . . . . . . . . . . 24

11 Containment Volume. • . . . • . . . . . . 29

12 Design Guidelines . . . . . . . . . . . . 30

13 Heating Tankage . . . . . . . . . . . . 31

14 Piping \& Values . . . . . . . . . . . . . 32

$1 j$ Typical Pre-heater Insulation \& Assembly. • . • 33

15 Preheat and Insulation System . . . . . . . . 34

17 System Design to Contain Sodium . . . . . . . 35

13 Sodium System Schematic . . . . . . . . . 36

19 Sodium Removal Reagents . . . . . . . . . . 37

2) General Sodium Cleaning Reagents. . . . . . . 38

21 System Differences from Fire Control Standpoint - 46

22 General Guidelines. . . . . . . . . . . . 47

23 SHR Containment Vessel \& Cell . . . . . . . . . 48

24 FFTF Compartmentation 1 . . . . . . . . . 49 
FFTF Compartmentation 2. . . . . . . . . 50

26 FFTF Compartmentation 3. . . . . . . . . . . . 51

27 Possible Sodium-Concrete Reaction Equations. . . 52

28 Liquid Level Devices . . . . . . . . . . . . 53

29 Basic principles . . . . . . . . . . . . 68

30 Reactor Safety Design Criteria . . . . . . . . 69

31 Heat Transfer Configuration Safety Features. • . . 70

$\equiv 2$ Typical Primary Component. . . . . . . . . . 71

33 LMFR Sodium Fire Protection Dates. . . . . . . 72

$\Xi 4$ Requirements for Plant Fire Protection System. . - 73

$\vdots 5$ Requirements for Piping \& Heat Transfer System • . 74

$\vdots 6$ Requirements for Heating \& Ventilation Systems • . 75

$\therefore 7$ Functions of the Cover Gas Purification Systems. - 76

i8 Requirements for Process Monitoring and Control

Systems. . . . . . . . . . . . . . 77

39 Maintenances of Sodium Systems Design Considera-

tions... . . . . . . . . . . . . . . 78

40 Safety Considerations and Facilities Systems

41 Keeping Moisture and Oxygen out of system. . . . 80

42 Liquid Metal Design Recommendations. . . . . . . 81

43 Liquid Metal Design Recommendations Continued. . 82

44 Sodium Cooled Reactor Cost Distributions . . . . . 83

15 Pot vs Loop Comparison . . . . . . . . . . . 84

16 Radioactive Effluents from Fast Powder Reactors. - 85

47 Progression of Sodium Through the Insulation . . . 86

18 Possible Fire Extinguishing. . . . . . . . . . . 87

49 Example of $\mathrm{N}_{2}$ Flooding System used in FFTF . . . . 38 
5) Compartments Flooded with $\mathrm{N}_{2}$ in FFTF . . . . 89

$5 \mathrm{l}$ Characteristics of Fire Extinguishing Agents. . 90

52 Performance of Fire Extinguishers........ . 91

53 Conditions of Fire Extinguishing Experiments . . 92

54 Insulations Materials. . . . . . . . . . 93

55 Sodium Fire Protection Methods in U.S. Sodium Facilities . . . . . . . . . . . . 9 94

56 Types of Sodium Leak Detectors . . . . . . 125

57 Leak Detectors . . . . . . . . . . 126

58 Types of Beads Leak Detectors Use........ 127

59 Containment Penetrations . . . . . . . . 128

60 U.S. Trench Details. . . . . . . . . . 129

61 German RIC-RAK Plate 1........... 130

62 German RIC-RAK Plate 2........... 131

63 German RIC-RAK Plate 3........... 132

64 French Catch Pan System 1........... 133

65 Franch Catch Pan System 2. . . . . . . . . 134

E6 UKAEA Catch Pan System............ . 135

67 Sodium Protective Suit . . . . . . . . 136

68 Protective Clothing. ........... 137

69 Personnel Protection from Liquid........ 138

i0 First Aid. . . . . . . . . . . . . 139

i1 Transport of Large Quantities of Sodium. . . . 140

i2 Suggestions for Sodium Handling. . . . . . . 141

i3 Barrel Container System for Liquid Metals. . . . 142

i4 Disposal of Waste Sodium . . . . . . . . . 143

$\because 5$ Liquid Metals Reactors . . . . . . . . . 146

'6 Liquid Metal Reactor Experience. . . . . . . . 147 
The motivation for writing this handbook is to place in context as much information as possible that would bear on the design of facilities for fire control engineering. Since sodium is by far the most used liquid metal coolant material, it serves as the guide for discussing and presenting the information. General principles will apply in large measure to all liquid metals. Certain specific differences will exist in details of the melting or boiling points, but handing and control can be accomplished by attention to basics.

This compilation came about through the desire of the Division of Operational and Environmental Safety, U.S. Department: of Energy, to have in one place information on the fire control engineering principles for 1 iquid metals. The target for this information is the designers and constructors of 1 iquid metal systems as well as fire control engineers and fire per:sonnel.

This information has been generated by several countries in the course of the development of the Fast Breeder Reactor conzept with the use of sodium as the coolant. Because the actual proprietary nature of some of the designs, not all of the information is available, but most of the basic or general items of interest are. Attempts to credit those who have contributed hav 2 been made, but in some cases the development has been so unirersal that no one person or group can be given the credit. It is sufficient to say that many have contributed to the storehouse of knowledge and have generously made it available for use.

It is hoped that this handbook will provide architectengineering people and facilities designers with sufficient guidelines to handle liquid metal coolant materials with a minimum of problems and to effectively design for fire control.

Part of the motivation for the handbook came from the compiler, who, as a member of the technical staff of one of the DOE Reactor 'Contractors, (1) was asked to bring together a course on sodium technology. For this course a thorough study was made of the available information on this subject. It was noted that many people had experience in liquid metals, but no one person really had a grasp of the entire field. It was thus necessary to bring together a large body of information with the help of many people in order to produce a text. The information in this handbook has the same reflection. Many people know part of the engineering technology, but there has been little compiled. We are herein attempting to compile information under the broad title of Liquid Metal Fire Control Engineering. since we feel that fire control in liquid metals starts with the earliest design of the facilities, we are approaching it from this point. 


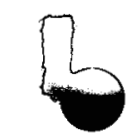

Q

R

7

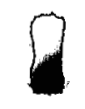

1.0 THE NATURE OF LIQUID METALS

B

1

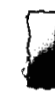



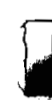

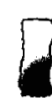
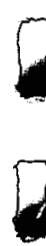

8

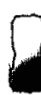

$\int$ 
The liquid metals are elemental metals, or alloys used at tenperatures where they are liquids. Examples are sodium, lithium potassium, lead, mercury, or combinations of these such as sodium and potassium $(\mathrm{NaK})$. Of those mentioned, only sodiumpotassium (NaK) alloys and mercury are liquid at room temperature. The balance require heating to bring them to a Ii guid state.

\subsection{WHY ARE THEY USED}

One of the great values of liquid metals is related to their very high thermal conductivity. That is the ability to transfer heat. Another advantage is the very wide boiling range. The wide liquid range allows the materials to be utilized as Iiquids without high pressures as is necessary with water (to 2200 psig) (see Figure 1). Water cooled reactors require the use of very high pressures to keep the water in a liquid state for efficient heat transfer. Water is an excellent cooling material, but to maintain it in its most efficient state, it is necessary to impose considerable pressure. In contrast, tree range of liquid metals from liquified phase to boiling point, is about $1000^{\circ} \mathrm{F}\left(538^{\circ} \mathrm{C}\right)$ at operating pressure. Liquid metal systems designed to remove the heat generated in the niclear reactor require pressures of 20 to 175 psig allowing significant economies in construction.

Some other advantages of liquid metal systems are their relative abundance and in some cases low cost. Sodium, for ez:ample, is the fourth most abundant element and is used extensively in chemical process industries, in both elemental and compound form.

As is often the case, there are pro's and con's in the use o: coolant materials. In the case of liquid metals, the most noticeable problem is that they are not always liquid at room temperature (see Figure 2). It requires trace heating of the piping or tankage holding it. System temperatures must be $r$ aised to at least $50^{\circ} \mathrm{F}\left(25^{\circ} \mathrm{C}\right)$ above the melting temperature to flow. Of equal concern is the compatibility of high temperature $\left(500-10000^{\circ} \mathrm{F}\right)\left(260-538^{\circ} \mathrm{C}\right)$ liquid metals with materials oE construction. Sodium, for example, is a very reactive miaterial as are most of the alkali metals. There are corrosion problems associated with use of liquid metals. Extensive developmental research has shown that corrosion can be ininimized wien they are kept very pure with respect to the contained oxygen. Reactors and test systems typically use sodium that contains less than $10 \mathrm{ppm}$ of oxygen. Procurement of low oxygen sodium is routine. Though experience is limited, this order of parity is thought to be required with all of the metals used in the liquid state. Before use, wisdom would certainly suggest 
compatability testing of metals other than sodium at temperatures of operation or as a minimum reference to the liquid metal haridbook

Another characteristic of liquid metals complicating their use: is reactivity with air. This requires them to be isolated from the atmosphere because the oxygen or nitrogen content of aij: reacts with them. If water is added to that atmosphere, either as water vapor or liquid, a further reaction takes place resulting in ignition because of the formation of $\mathrm{H}_{2}$. Conta:. nment of liquid metals in general, requires materials to be isclated in inert atmospheres. The atmospheres most often used are argon, helium, and nitrogen. Use of nitrogen is limited to low system temperatures because nitrogen reacts with the containment materials near $1000^{\circ} \mathrm{F}\left(538^{\circ} \mathrm{C}\right)$ resulting in nitriding or surface hardening. Nitrogen canrot be used with lithium syistems. Note this limitation! Argon and helium in contrast ar $\geqslant$ inert at all operating temperatures. Argon is a relatively abindant gas and hence has a more universal application. Figure 3 shows some basic properties of inert gases. (2)

Water and its reaction with liquid metals is of considerable concern in fire control engineering. It is here that liquid metals differ significantly from other coolant materials. A I iquid metal system requires a marked deviation from conventional fire control procedures. A conventional reactor system can be protected by the application of sprinklers. This option is not always available for a liquid metal cooled system because water and sodium combine to form hydrogen and heat sufficient to ignite, and have been known to be violent. Considerable ingenuity has been used to overcome these difficulties. This has resulted from application of the fundamental principles $r \in q u i r e d$ to extinguish fires. These would be cooling, and removal or restriction of the oxygen source to stop the combustion process. The careful use of inert atmospheres and the application of powdered chemical agents can control liquid metal fires. Different techniques are required for controlling liquid metal fires as compared with conventional fires (see Figure 4). Tris problem is approached by designing for separation of liquid metal facilities so that non-water fire control can be accomplished more effectively. This will be discussed later in greater detail.

Two other characteristics of liquid metals need mentioning. First, they expand upon heating, so design of systems need to consider the change in volume. This amounts to an increase ol: about $3 \%$ by volume for sodium noving from the solid to ljquid state, and about 128 expansion by volume going from the meliting point to $1000^{\circ} \mathrm{F}\left(538^{\circ} \mathrm{C}\right)$. This requires systems heatup procedures to work from the free surface of a tank where there is; always an area molten to accomodate expansion. Second, burning liquid metals expand as they form oxide compounds. It is: normally assumed that $100 \%$ of the contained volume of sodium woild be adequate for containment in a catch pan beneath the 
tank or pipe. However, the products of combustion or reaction terd to be much less dense and hence of larger volume. And although up to one third of the sodium can be released as fume, the catch volume should be in excess of the 1008 for safety sake. It is recommended that this be no less than $125 \%$ to 1508. Experimental evidence also show products of combustion tend to creep up containment walls through wetting and capillary $r$ ise phenomenon.

Note also that extended high temperature containment of licuid metals requires use of welded pipe joints. Liquid metals gerierally are very fluid and have the ability to find any existing leakage paths to the atmosphere. Welded connections are: generally better constructed and hence more reliable.

After learning of the peculiarities of liquid metals encineers might wonder why these materials are considered for use:. It is because the advantages of liquid metals, utilizing low pressures and high heat transfer, significantly offset the disadvantages. The higher thermal efficiency of liquid metal reactors and their more efficient use of the uranium resources make liquid metal systems extremely viable and useful. There have been substantial verification of all these advantages in the: world wide operations.

\section{$1 . \Xi$ CHARACTERISTICS OF LIQUID METALS}

This section is included in order to place in context the chemical, physical, and nuclear properties of these materials. Refierence to them will allow a clearer picture of use as well as provide a self-contained reference that will allow the fire control engineer to have this information at his fingertips. Apjended likewise is a section on actual properties that will al.Low accurate computation to be used (see Figures $5,6,7,8$, and 9$).(1,3)$ 


\section{GENERAL REASONS FOR USING LIOUID METALS}

- high theRMAL CONDUCTIVITY

- HIGH BOILING POINT - LOW MELTING POINT

- STABILITY to heat AND RADIATION

- COMPATIBILITY WITH MATERIALS IN PURE STATE

- LOW - COST AND ABUNDANT (SODIUM AND NAK ONLY)

- high ELECTRICAL CONDUCIVITY

- GOOD NEUTRONICS

- DESIRABLE INDUCED RADIATION PROPERTIES

\section{FIGURE 1}




\section{PROBLEMS RELATED TO LIQUID METALS}

- MOST ARE NOT LIQUID AT ROOM TEMPERATURE (EXCEPTIONS, NaK, Hg.)

- REQUiRES tRACE heAtiNg to liQuid temperature PLUS $77^{\circ} \mathrm{F}\left(25^{\circ} \mathrm{C}\right)$

- REQUIRES ALL WELDED CLOSED SYSTEMS FOR EXTENDED SERVICE

- REQUIRES INERT GAS COVERAGE (ARGON, NITROGEN, HELIUM)

- HIGH THERMAL EXPANSION-SPECIAL DESIGN

- FROST OR AEROSOL OCCURS AT $500-1000^{\circ} \mathrm{F}\left(260-538^{\circ} \mathrm{C}\right)$

- VISIBILITY IMPAIRED DURING A FIRE DUE TO DENSE SMOKE

- CORROSIVE IN CONTACT WITH AIR/WATER

- OFTEN INCOMPATIBLE WITH WATER AND MANY ORGANIC COMPOUNDS 


\section{PROPERTIES OF INERT GASES}

COMMERCIAL GUARANTEED SPECIFICATIONS* FOR HELIUM, ARGON, AND NITROGEN

\begin{tabular}{|c|c|c|c|c|}
\hline CCINTENT & & HELIUMa & ARGON & NITROGEN \\
\hline GAS TOTAL PURITY & (MIN \%) & 99.9976 & $99.9+$ & 99.99 \\
\hline OXYGEN & (MAX\%) & 一 & 0.002 & 0.002 \\
\hline H'DROGEN & (MAX\%) & 0.00003 & 0.002 & 0.002 \\
\hline NITROGEN & $(\mathrm{MAX} \%)$ & 0.001763 & 0.001 & - \\
\hline CARBONb & $(\operatorname{MAX} \%)$ & - & 0.003 & $\longrightarrow$ \\
\hline MIETHANE & (MAX \%) & 0.000001 & - & - \\
\hline CARBON DIOXIDE & $(\operatorname{MAX} \%)$ & 0.000581 & $\longrightarrow$ & - \\
\hline AIRGON & $(\operatorname{MAX} \%)$ & 0.000049 & - & - \\
\hline TOTAL GAS IMPURITIES & $(\mathrm{MAX} \%)$ & - & 0.01 & 0.01 \\
\hline MIJISTURE (DEW POINT F) & & - & -76 & -76 \\
\hline
\end{tabular}

* COURTESY OF AIR REDUCTION SALES CO. AND LINDE AIR PRODUCTS CO.

a TYPICAL ANALYSIS BY BUREAU OF MINES, COURTESY OF AIR REDUCTION SALES CO.

b ALL FORMS - TOTAL

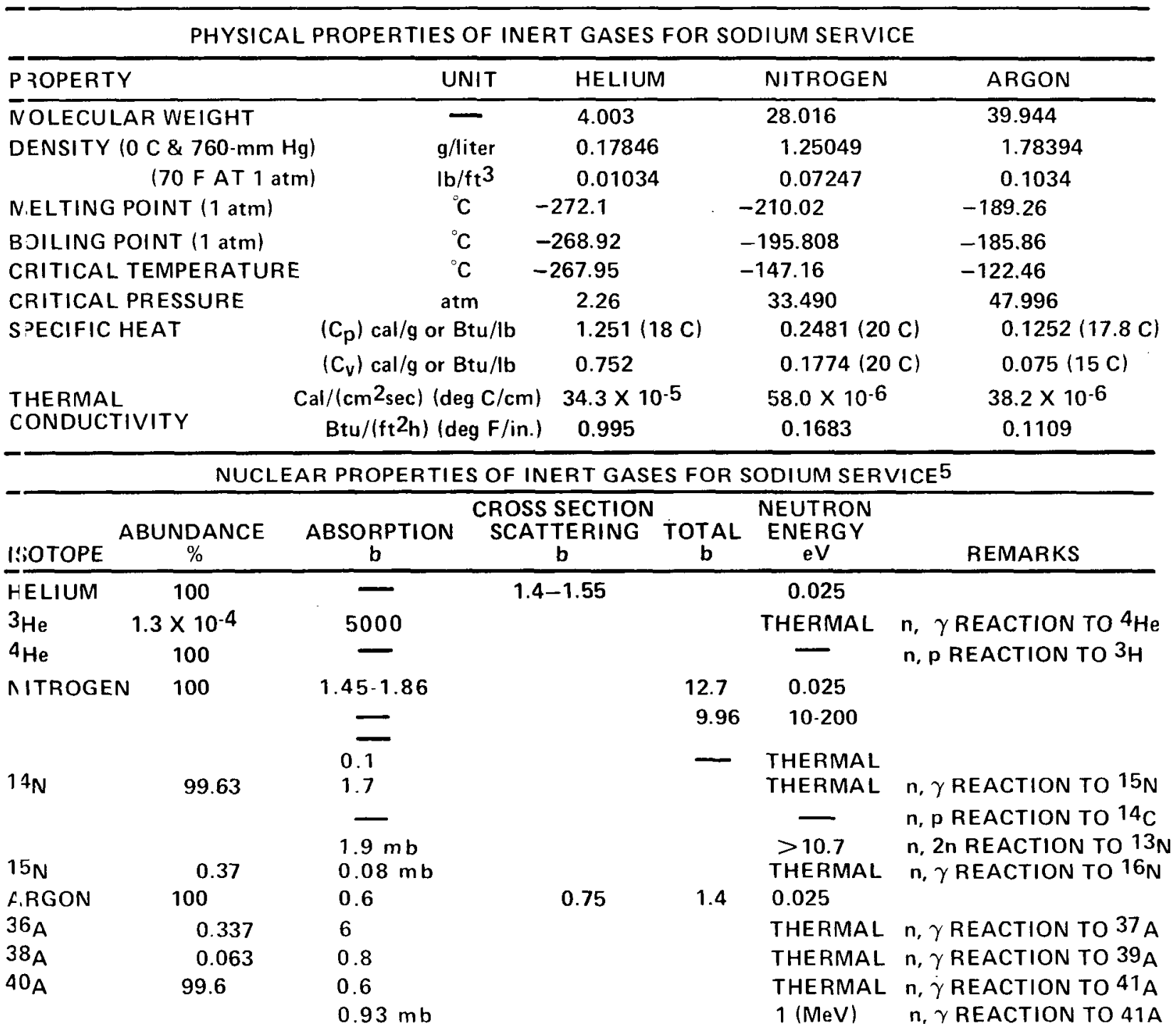




\section{HOW TO FIGHT LIQUID METAL FIRES}

- eliminATE OXYGEN

- DON'T USE WATER (OR ORGANICS)

- cool down (BLANKET MASS WITH POWDER AND WAIT)

- clean up residue (use metal cans PLUS LAYERING WITH POWDER EXTINGUISHER MATERIAL)

- REMOVE FOR DISPOSAL

- USE PROPER PROTECTIVE CLOTHES (COVERALLS, HARD HAT, FACE SHIELD, GOGGLES, GLOVES, LEGGINGS, AND SAFETY SHOES)

- hAVE RESPIRATORY EQUIPMENT AVAILABLE

- IF POSSIBLE DRAIN LIQUID METAL TO DUMP TANK OR CONTAINER UNDER PROTECTION OF INERT ATMOSPHERE OF A SUMP TO DECREASE EXPOSED SURFACE AREA

\section{FIGURE 4}




\section{PHYSICAL PROPERTIES OF SODIUM}

APPEARANCE ..... SOFT, MALLEABLE, SILVERY WHITE SOLID

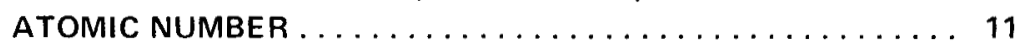

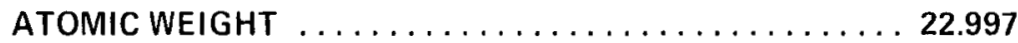
BOILING POINT .................. $883^{\circ} \mathrm{C}\left(1,621^{\circ} \mathrm{F}\right)$ ELECTRICAL RESISTIVITY, microhms $/ \mathrm{cm}, 100^{\circ} \mathrm{C}\left(212^{\circ} \mathrm{F}\right) \ldots 9.65$ HEAT OF FUSION @ $97.5^{\circ} \mathrm{C}\left(207.5^{\circ} \mathrm{F}\right), \mathrm{cal} / \mathrm{g} \ldots \ldots \ldots \ldots \ldots 27.2$

Btu/lb .....48.96 HEAT OF VAPORIZATION AT $883^{\circ} \mathrm{C}\left(1,621^{\circ} \mathrm{F}\right)$, cal $/ \mathrm{g} \ldots \ldots 1,005$ Btu/lb ..... 1,809 MELTING POINT $97.5^{\circ} \mathrm{C}\left(207.5^{\circ} \mathrm{F}\right)$

DENSITY:

TEMPERATURE

SOLID $\ldots . . . . . . . . .$.

SOLID ......... 0

LIQUID . . . . . . . . 97.5

100

145

250

400

600

800

\section{C}

.5

5

.5

5

0

0

0

LB PER CU FT, SOLID AT $97.5^{\circ} \mathrm{C}\left(207.5^{\circ} \mathrm{F}\right.$ LB PER GAL, LIOUID AT $97.5^{\circ} \mathrm{C}\left(207.5^{\circ} \mathrm{F}\right)$ VOLUME CHANGE ON FUSION . . ..... $2.4 \%$ OF SOLID VOLUME 


\section{PHYSICAL PROPERTIES OF SODIUM CONTINUED}

\begin{tabular}{|c|c|c|c|c|c|}
\hline \multicolumn{3}{|c|}{ SPECIFIC HEAT: } & & \multirow{2}{*}{$\begin{array}{c}\text { Btu } \\
\text { PER POUND } \\
\text { PER }{ }^{\circ} \mathrm{F}\end{array}$} \\
\hline & ${ }^{\circ} \mathrm{C}$ & ${ }^{\circ} \mathrm{F}$ & PER ${ }^{\circ} \mathrm{C}$ & & \\
\hline \multirow[t]{3}{*}{ SOLID } & 0 & 32 & & 0.2930 & \\
\hline & 20 & 68 & & 0.2985 & \\
\hline & 97.5 & 207.5 & & 0.3266 & \\
\hline \multirow[t]{4}{*}{ LIQUID. } & 97.5 & 207.5 & & 0.3340 & \\
\hline & 100 & 212 & & 0.3305 & \\
\hline & 150 & 302 & & 0.3369 & \\
\hline & 200 & 392 & & 0.3199 & \\
\hline
\end{tabular}

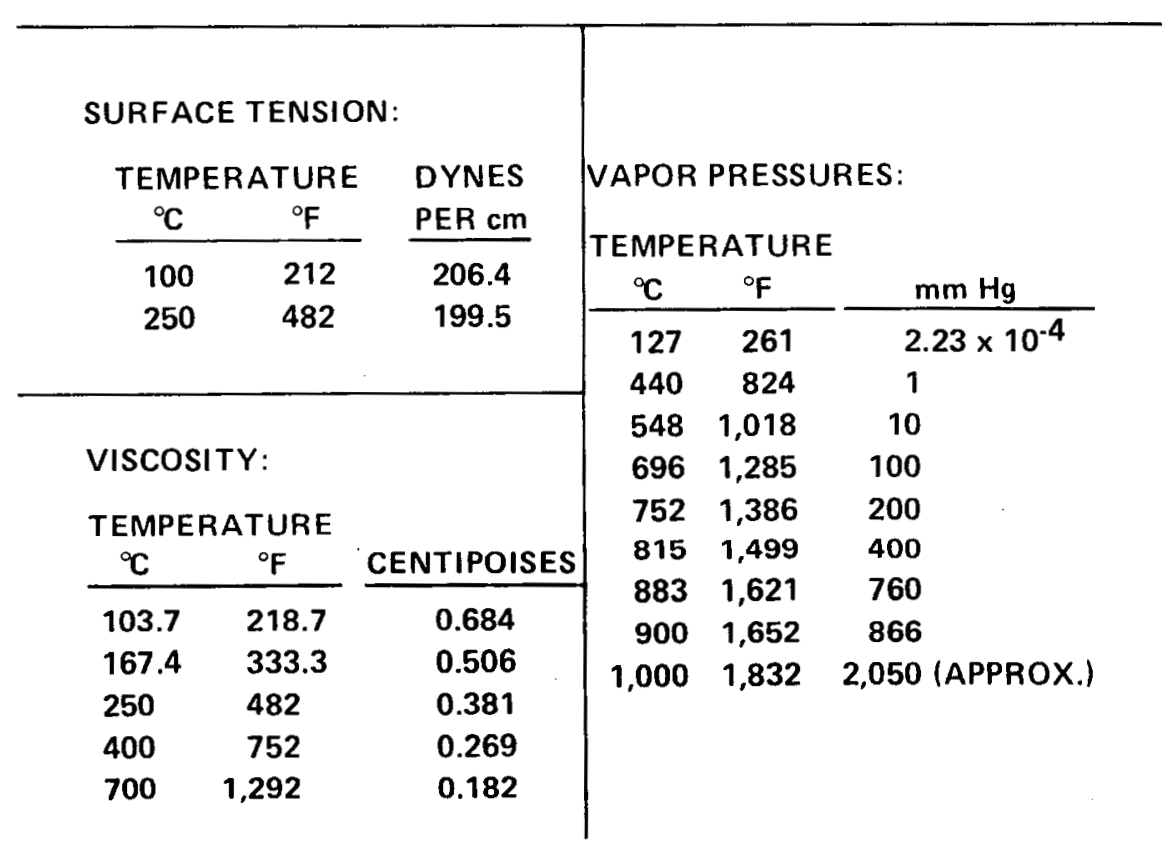

FIGURE 6 


\section{RADIOLOGICAL IMPLICATIONS ON DESIGN FOR SODIUM}

(NEUTRON CAPTURE CROSS-SECTION)

- NUCleAR REACtions of SODIUM

HALF LIFE

$$
\mathrm{Na}^{23}+\mathrm{n} \rightarrow \mathrm{Na}^{24}+\gamma
$$

$\mathrm{Na} 23+n \rightarrow \mathrm{Na}^{22}+2 \mathrm{n}$
$15 \mathrm{hr}$

$2.6 \mathrm{yr}$
DECAY ENERGY (MEV)

$$
\begin{gathered}
1.38 \gamma \\
2.76 \gamma \\
\beta \\
1.28 \gamma \\
\beta+
\end{gathered}
$$

- ACTIVITY DURING NORMAL OPERATION (Specific for a 500 MWe FBR)

SPECIES

$$
\begin{aligned}
& \mathrm{Na} 24 \\
& \mathrm{Na} 22
\end{aligned}
$$

CORROSION PRODUCTS $\mathrm{Mn}, \mathrm{Co}_{\mathrm{o}} \mathrm{Fe}$

FISSION PRODUCTS

CESUIM IODINE
SPECIFIC ACTIVITY

(Ci/cc)

$$
\begin{aligned}
& 4.56 \times 10^{-2^{* *}} \\
& 1.47 \times 10^{-6}
\end{aligned}
$$

$5 \times 105$

\section{3}

210

10

*INTERMEDIATE HEAT EXCHANGER

**IF $10 \mathrm{cc}$ 's OF THIS MATERIAL WERE BURNED IN THE REACTOR BUILDING (AFTER A SPILL), MPC*** WOULD BE EXCEEDED. (ASSUMES COMPLETE BURNING \& MIXING)

*** MPC = MAXIMUM PERMISSIBLE DOSE

FIGURE 7 


\section{RADIOLOGICAL IMPLICATIONS ON DESIGN FOR SODIUM \\ $500 \mathrm{MWeFBR}$}

- ACTIVITY AFTER SHUTDOWN

\begin{tabular}{|c|c|c|c|c|}
\hline SPECIES & $\begin{array}{l}\text { DOSE RATE } \\
\text { NEAR } \\
\text { DRAINED IHX ** }\end{array}$ & $\begin{array}{c}\text { MAINTENANCE } \\
\text { TIME /3 mo } \\
\end{array}$ & $\begin{array}{l}\text { DOSE RATE } \\
\text { NEAR IHX } \\
\text { AFTER } 2 \text { weeks } \\
\end{array}$ & $\begin{array}{l}\text { MAINTENANCE } \\
\text { TIME/4 mo }\end{array}$ \\
\hline $\mathrm{Na}^{24}$ & $2 \times 10^{3} \mathrm{R} / \mathrm{hr}$ & $2 \mathrm{sec}$ & $0.2 \mathrm{MR} / \mathrm{hr}$ & \\
\hline $\mathrm{Na} 22$ & $4 \times 10^{-2} \mathrm{R} / \mathrm{hr}$ & $30 \mathrm{hr}$ & $4 \times 10^{-2} \mathrm{R} / \mathrm{hr}$ & $30 \mathrm{hr}$ \\
\hline $\begin{array}{l}\text { CORROSION } \\
\text { PRODUCTS }\end{array}$ & $210 \mathrm{R} / \mathrm{hr}$ & $20 \mathrm{sec}$ & $210 \mathrm{R} / \mathrm{hr}$ & $20 \mathrm{sec}$ \\
\hline $\begin{array}{l}\text { FISSION } \\
\text { PRODUCTS }\end{array}$ & $10 \mathrm{R} / \mathrm{hr}$ & $7 \mathrm{~min}$ & $8.5 \mathrm{R} / \mathrm{hr}$ & $8 \mathrm{~min}$ \\
\hline$* * 1 H X=1$ & DIATE HEAT EXC & & & \\
\hline
\end{tabular}

FIGURE 8 


\section{RADIOACTIVITY LEVELS IN SODIUM AT SATURATION - 500 - MWe FBR*}

*FAST BREEDER REACTOR

PRIMARY COOLANT

$\begin{array}{cc}\mathrm{Na} 24 & 50,000 \mu \mathrm{Ci} / \mathrm{cc} \text { PRIMARY SODIUM } \\ \mathrm{Na} 22 & 2\end{array}$

$1 \%$ FAILED FUEL, $0.1 \%$ LEAKAGE

\begin{tabular}{|c|c|}
\hline Cs 137 & $0.7 \mu \mathrm{Ci} / \mathrm{cc}$ \\
\hline 131 & 0.7 \\
\hline $\mathrm{Sr} 90$ & 0.02 \\
\hline $\mathrm{Pu} 238,239$ & 0.001 \\
\hline TOTAL & 1.42 \\
\hline
\end{tabular}

CORROSION PRODUCTS, $1 \mathrm{mil} / \mathrm{yr}$

\begin{tabular}{|c|c|}
\hline $\mathrm{Cr} 51$ & $9 \mu \mathrm{Ci} / \mathrm{cc}$ \\
\hline$M n 54$ & 60 \\
\hline $\mathrm{Fe}^{59}$ & 2 \\
\hline $\mathrm{Co}^{58}$ & 90 \\
\hline $\mathrm{Co}^{6} 60$ & 30 \\
\hline TOTAL & 191 \\
\hline
\end{tabular}

FIGURE 9 
2.0 CHEMICAL AND PHYSICAL PROPERTIES OF LIQUID METALS
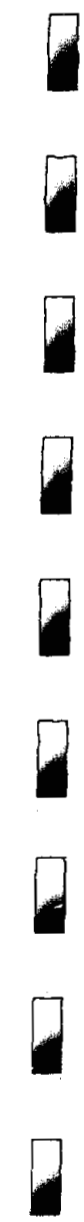


\title{
2.0 CHEMICAL AND PHYSICAL PROPERTIES OF LIQUID METALS
}

\begin{abstract}
Some chemical and physical properties of sodium having a relevancy to fire safety are sumarized below. (4)
\end{abstract}

Air

Nit.rogen

He]. ium and Argon

Carbon dioxide

$\underline{\text { Stegam }}$

Ha:logens

Wa: $:$ er

Alizohols

Hy irocarbons

Chlorinated

Hy drocarbons
Sodium reacts with $\mathrm{O}_{2}$ and $\mathrm{H}_{2} \mathrm{O}$ in air at all temperatures. In atmospheres containing 5 or or more oxygen by volume, high temperature, liquid sodium reacts readily and may ignite.

Sodium at $1472^{\circ} \mathrm{F}\left(800^{\circ} \mathrm{C}\right)$ will react with nitrogen at $1832^{\circ} \mathrm{F}\left(1,000^{\circ} \mathrm{C}\right)$. Azide or nitride can thus be formed.

In these atmospheres sodium will not react.

Gaseous carbon dioxide is decomposed by burning sodium. A Inixture of solid carbon dioxide and (molten) sodium is explosive when struck.

Sodium reacts quietly with dry steam to form hydroxide and hydrogen.

Sodium will ignite spontaneously with fluorine at room temperature and with chlorine around $212^{\circ} \mathrm{F}\left(100^{\circ} \mathrm{C}\right)$.

Sodium reacts with water liberating hydrogen which in air forms a mixture which may explode when the metal ignites.

With low molecular weight alcohols, sodium reacts to liberate hydrogen more slowly than with water. Reaction rates decrease as the alcohol molecular weight increases.

It is reported that some kerosenes can be heated safely in the presence of sodium.

Sodium organo compounds formed under specified conditions, ignite spontaneously in air.

Sodium Inay explode when in contact with chlorinated hydrocarbon liquids, e.g., carbon tetrachloride, chloroform, trichloroethylene. 
Ammonia Liquid

Mineral Acids
Sodium is partly soluble in liquid ammonia and in the presence of a catalyst such as iron, sodium amide is formed. Sodium amide is explosive in air under some conditions.

Sodium explodes on contact with hydrochloric acid and ignites spontaneously in contact with nitric acid of $s p$. grav. exceeding 1.056. With sulphuric acid, the violence of the reaction is inversely proportional to the normality of the acid.

Comments on Reaction of Sodium Fume and $A$ ir

Sodium in finely divided form is pyrophoric, (meaning it ignites immediately upon exposure to air at ambient temperature) while a pool of metal may not burn until its temperature reaches $752^{\circ} \mathrm{F}$ $\left(4000^{\circ} \mathrm{C}\right)$ or higher. Factors which contribute to this wide difference in ignition temperatures are:

(a) Surface to Volume Ratio Particles of metal arising from condensed vapor or sodium in the 1 to $10 \mathrm{micron} r a n g e$ have a very high specific surface and are pyrophoric.

Liquid metals in droplet form (spray) from a closed systein are likely to ignite immediately upon contact with air. A solid stream of liquid metal (low surface area) from a fractured pipe or vessel may not ignite unless the sodium is at or above a temperature of about $392^{\circ} \mathrm{F}\left(200^{\circ} \mathrm{C}\right)$.

Pool ignition temperatures vary widely. When metal at a temperature of $392^{\circ} \mathrm{F}$ $\left(2000^{\circ} \mathrm{C}\right)$ escapes from a system and forms a pool, immediate ignition is likely. However, factors such as the geometry of the pool, cooling. local ventilation, and the mode of heating the metal all influence the ignition temperature.

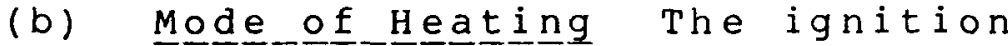
temperature of sodium varies with the manner of heating. It begins at about $250^{\circ} \mathrm{F}\left(120^{\circ} \mathrm{C}\right)$ when air is excluded 
from contact and continues until the metal has liquefied. When solid sodium is heated in air, oxide accumulates on the surface and prevents ignition until temperatures in the $527-797^{\circ} \mathrm{F}$ (275$\left.425^{\circ} \mathrm{C}\right)$ range are attained. When the layer of surface oxide is disturbed the ignition temperature falls to about $392^{\circ} \mathrm{F}\left(200^{\circ} \mathrm{C}\right)$. 


\subsection{THE BURNING OF SODIUM}

The thermochemical data for the principle reactions which occur when sodiun is burning in air are as follows:

Reaction with oxygen

$$
\begin{aligned}
& 2 \mathrm{Na}(\mathrm{L})+\frac{1}{2} \mathrm{O}_{2}-\mathrm{Na}_{2} \mathrm{O}_{(\mathrm{S})} \\
& 2 \mathrm{Na}(\mathrm{L})+\mathrm{O}_{2}-\mathrm{Na}_{2} \mathrm{O}_{2}(\mathrm{~S})
\end{aligned}
$$

$$
\begin{aligned}
& \Delta \mathrm{H}_{298}=-104 \mathrm{Kcal} / \mathrm{mole} \quad 1 . \\
& \Delta \mathrm{H}_{298}=-124 \mathrm{Kcal} / \mathrm{mole} \quad 2 \text {. }
\end{aligned}
$$

Reaction with water Vapor

$$
\begin{aligned}
& \mathrm{Na}(\mathrm{L})+\mathrm{H}_{2} \mathrm{O}>\mathrm{NaOH}+\frac{1}{2} \mathrm{H}_{2}(\mathrm{G}) \quad \Delta \mathrm{H}_{298}=-90 \mathrm{Kcal} / \mathrm{mole} \quad 3 \text {. } \\
& \frac{1}{2} \mathrm{Na}(\mathrm{L})+\frac{1}{2} \mathrm{H}_{2} \mathrm{O}>\mathrm{NaOH} \quad \Delta \mathrm{H}_{298}=-17 \mathrm{Kcal} / \mathrm{mole} \quad 4 \text {. } \\
& \frac{1}{2} \mathrm{Na}_{2} \mathrm{O}_{2}+\frac{1}{2} \mathrm{H}_{2} \mathrm{O}>\frac{1}{2} \mathrm{O}_{2}(\mathrm{G})+\mathrm{NaOH} \Delta \mathrm{H}_{298}=-17 \mathrm{Kcal} / \mathrm{mole} \quad 5 \text {. }
\end{aligned}
$$

Since the water content in the air is small with respect to the oxygen, reactions represented by Equations 3 to 5 play a siubordinate part in heat release.

The reaction which occurs in accordance with Equation 1 represents the burning of liquid sodium to sodium oxide in coltainment where there is an excess of liquid metal (see Ficjure 10).(5) Under conditions where oxygen is available to support burning, the formation of sodium peroxide (Equation 2) is favored up to $1200^{\circ} \mathrm{F}\left(650^{\circ} \mathrm{C}\right)$. Above this temperature, the peroxide decomposes into sodium oxide and oxygen. Large teists show the aerosol to be $\mathrm{Na}_{2} \mathrm{O}_{2}+\mathrm{NaOH}$.

A summary of experimental work(4) has shown that the burning rate of sodium varies between 2 to $45 \mathrm{~g} / \mathrm{sec} / \mathrm{m}^{2}$ of reacting metal surface ( 1.3 to $\left.33 \mathrm{lb} / \mathrm{hr} / \mathrm{ft}^{2}\right)$. Assuming the me:al goes to the peroxide, this corresponds to a heat output of be wween $2.3 \times 10^{4}$ to $5.1 \times 10^{5} \mathrm{~J} / \mathrm{sec} / \mathrm{m}^{2}$ (19 to $\left.44 \mathrm{Btu} / \mathrm{sec} / \mathrm{ft}^{2}\right)$.

It is reported(4) that two-thirds of the combustion reaction of sodium occurs in the vapor phase with the balance taking place at the liquid surface. The reaction rate is determined by the vaporization rate of the metal, controlled by the rate of transport (including diffusion) of oxygen into the coinbustion zone. Sodium fires can therefore be subdivided into those occurrences where the metal burns as a pool and those where the metal is ejected in spray form from a leak or rupture in the plant piping system. In general the pool fire is characterized by a much slower rate of burning than in the spray fire, due to 1 imited access of oxygen to the reaction zone.

Some comparative heat releases for sodium and common flammable materials are the following: (4) 
Sod i um

Wood

Methyl Alcohol

Biturninous Coal

Oi 1 $\sim 5,000 \mathrm{BTU} / \mathrm{lb}$

$\sim 8,000 \mathrm{ETU} / 1 \mathrm{~b}$

$\sim 10,000 \mathrm{BTU} / 1 \mathrm{~b}$

$\sim 14,000 \mathrm{BTU} / \mathrm{Lb}$

$\sim 20,000 \mathrm{BTU} / \mathrm{lb}$

Flane height sodiun flames rarely attain a height of more than a few inches. Flames from hydrocarbons extend several feet abore the liquid surface because of the ignition of the volatile gas given off.

Convection currents The convection currents produced by sodium fires are of sinaller volume and lower intensity than those arising from the combustion of an equivalent amount of organic materials.

Radiant heat The radiant heat from a sodium fire is much Ies.j intense than from burning carbonaceous materials. This is because sodium has no flammable volatile gaseous phase driven off to continue burning as do hydrocarbonaceous materials.

The effects of sodium fires should not be underrated as they can be serious. The metal burning as a spray, or as a pool of large surface area or high temperature may build up pressure and cause building damage. Sodium metal and sodium fume corcosion products arising from combustion can impair equipment severely. The fumes evolved from a sodium fire of comparatively small size, quickly reduces visibility to a yard or less. The caustic and irritating nature of the combustion products make them unpleasant to breathe. Personnel exit rapidly rather than taking time to shut down or fight the fire. An appreciation of the fume hazard will be gained from the following table of measured concentrations and some qualitative statements about human tolerance: (These should not be construed to be 1 imits or standards but were arrived at by experimentation.) 
SODIUM FUME HAZARD (4)

Concentration of

Fume in $A$ ir

$2 \mathrm{mg} / \mathrm{m}^{3}$

$50 \mathrm{mg} / \mathrm{m}^{3}$

$.00 \mathrm{mg} / \mathrm{m}^{3}$

$200 \mathrm{mg} / \mathrm{m}^{3}$

\section{Effect}

Acceptable for continuous exposure.

Tolerable for $2-5$ minutes. Visibility reduced to under 50 feet.

Eye and lung discomfort. Serious loss of visibility, conditions intolerable.

Visibility zero.

Note: The American Conference of Industrial Hygienists 1 ist the threshold limit value for $\mathrm{NaOH}$ at $2 \mathrm{mg} / \mathrm{m}^{3}$ for occupational exposure ( 40 hour week) ${ }^{6}$ and short time maximums at $4 \mathrm{mg} / \mathrm{m}^{3}$ as long as the weighted average over an 8 hour period does not exceed $2 \mathrm{mg} / \mathrm{m}^{3}$. The same body has proposed $25 \mathrm{mg} / \mathrm{m}^{3}$ for sodium oxide. 


\section{POSSIBLE CHEMICAL MECHANISM FOR THE BURNING OF SODIUM}

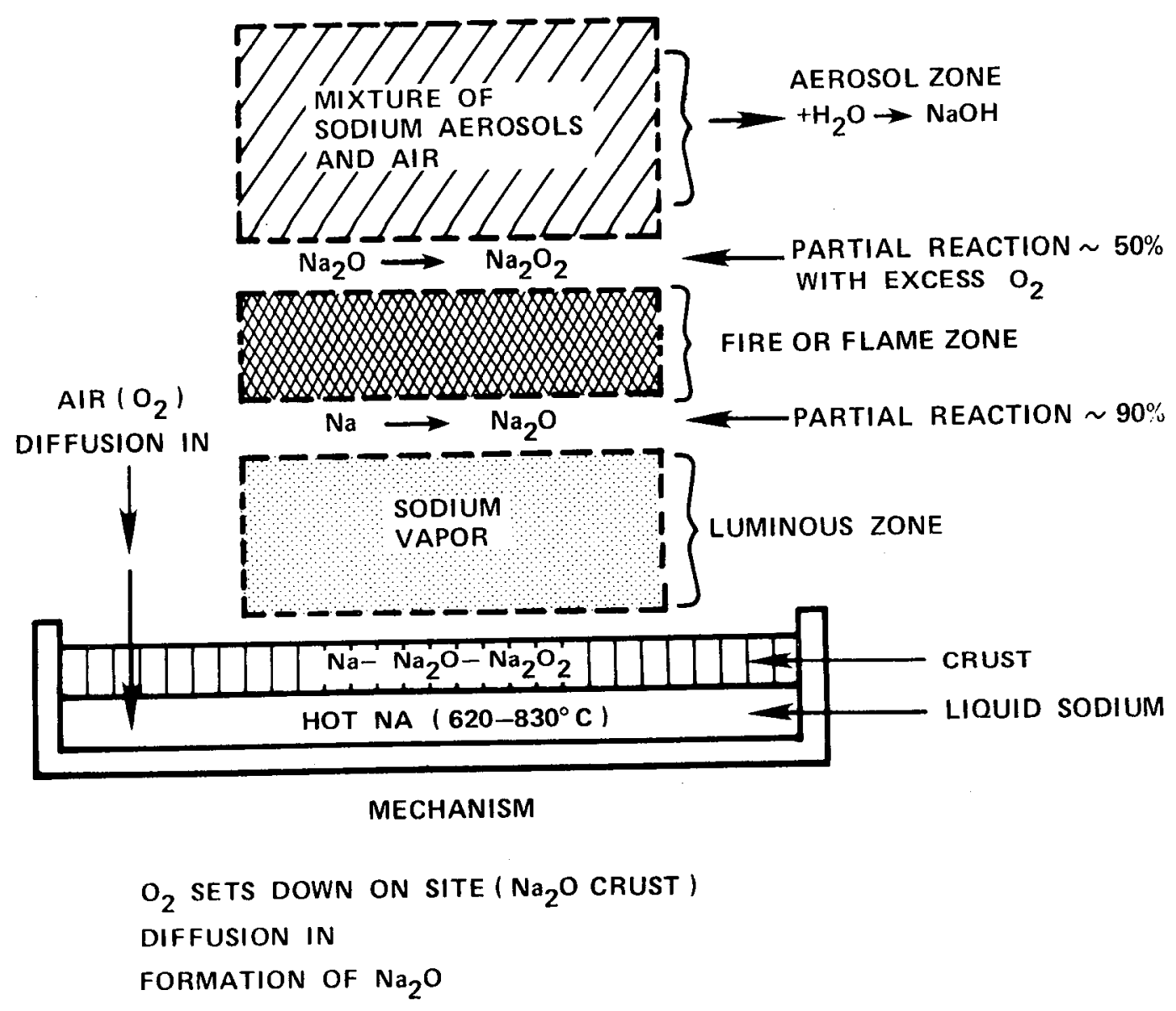

FIGURE 10 
4.0 BASIC CONCERNS IN THE USE OF LIQUID METALS 


\subsection{BASIC CONCERNS IN THE USE OF LIQUID METALS}

These concerns are described in terms of sodium, which is by far the most widely used liquid metal coolant. However, there is a general application in principle to all liquid metils.

\subsection{CONTAINMENT}

Liquid metal systems require tanks and connecting piping for containment and use. The basic requirement is a compatible containment material (usually 300 series stainless steel because of high temperature requirement and good compatibility) and the assiciated all-welded structures. Since leaks must be avoided for fire control and for control of nuclear contamination, welding and highly controlled fabrication techniques are required. Stringent component fabrication codes require radiographing and disciplined quality control be imposed on these systems. Design requires the application of ASME Boiler Code to insure safe operation at high temperatures (see Figare 11).

In design, no openings should be placed in the system except at the top of tanks(7) (see Figure 12). Openings should then be welded closed. An exception to this is a filling operation. Since filling operations are generally short term, a matter of hours, nonwelded or compression fittings can be used. These, however, require surveillance to insure their integrity and are satisfactory for short intermittent service.

Since liquid metal systems require use of trace heating to keep them liquid, they are enclosed with insulation to conserve heat. Thus a high degree of reliability in fabrication is required for the systems (see Figures 13, 14, 15, 16).(8) System reliability during fabrication and assembly is emphasized because insulation covers up possible leaks and makes them much more difficult to find. Liquid metal systems often incorporate a network of electrical contacts or electronic leak detectors to assist in monitoring system integrity.

The containment philosophy has two goals: first, to keep the sodium in, and second, to keep the air (oxygen) out. Designs of nonradioactive liquid metal systems try to maintain slightly higher ambient pressures internally in order to keep air out and to prevent contamination of the system (see Figure 17).

\subsection{SOLID-LIQUID PHASE}

It was noted that most 1 iquid metals are solid at room temperature. They therefore, require means of heating from room temperature to about $50^{\circ} \mathrm{F}\left(25^{\circ} \mathrm{C}\right)$ or more above the melting point. This operation is accomplished by use of trace heaters. 
These are calrod type heaters, either in the form of bands, or as round sections firmly attached to the piping or tankage by welding or banding. This promotes efficient heat transfer to the system (see Figures 13-16). The application of trace heating creates problems for designers and fire control people, because it is difficult to determine where a leak is located in the system. This can be seen in the figures attached. Always associated with nuclear systems are remote indicating devices or sensors to determine if a leak is present. These devices are discussed in nore detail as part of the fire detection and location system.

System heating introduces the need to accommodate expansion of the liquid metal coolant. The system supply tank is the solrce of sodium. It is heated together with the piping system to $50^{\circ} \mathrm{F}\left(25^{\circ} \mathrm{C}\right)$ or more above the melting point of the material. The coolant is then pumped into place. In the event of a shutdown, practice is to drain or dump the system and put the coolant back into the supply tank (see Figure 18). However, in the event the coolant will not return to the tank, it may be necessary to solidify the liquid metal in place by system cocling. If this occurs, the remelting of system must be accomplished with care. The primary reason is the volume exfansion accompanying the solid to liquid phase transformation and that relating to ascension to operating temperature. It is necessary to make the heatup start from a free surface to take care of expansion. Failure to follow this procedure will cause undue stress on the system piping and can cause pipe failure. current practice in large systems is for $50^{\circ} \mathrm{F}\left(25^{\circ} \mathrm{C}\right.$ ) per hour as the maximum heatup rate specified. This allows the thermal stresses to redistribute themselves without over-stressing the system. Often the thermal inertia of the system will limit the heatup rate to a lower value. Especially critical components should be held under $10^{\circ} \mathrm{F}\left(5^{\circ} \mathrm{C}\right)$ per hour to allow thermal equilibrium in heatup.

$4 . \Xi \quad$ INERT ATMOSPHERES

It has been mentioned that chemical reactivity of the 1 icluid metals with air requires inert gas atmospheres be maintained over the systems. It was noted that argon and helium are: the most used inert gases. Nitrogen is useful if the temperature is low. It should not be assumed that the nitrogen or gases other than argon and helium are compatible for all licluid metal, but rather each liquid metal should have identieied those gases that can be used without difficulty. For example, 1 ithium is not compatible with nitrogen at any temperature. (9)

The presence of the inert gas also presents problems in file control. First, its presence is a source of concern because of resulting oxygen deficient atmospheres. Therefore, frcm a safety point of view, be on guard for these conditions. Sorletimes inert gases are used in compartment flooding for 
fir» control. Here, an even greater probability of the oxygen deficiency should be assumed. The inert gas systems for routine atmisphere control should be separate from supplies used for fire control for reliability reasons.

Second, in the nuclear systems, inert atmospheres may be contaminated with radioactivity, hence special off-gas handling or recirculation systems are necessary. Purification of off-normal gases generated under emergency conditions will also require processing. These will be part of the total system requirements.

\subsection{WETABILITY OF SUREACES}

Liquid metals have different abilities to wet surfaces and generally wetability is a function of temperature. This can be a plus or a minus depending on the conditions desired. In most cases, unclean surfaces will result in raising the wetting temperature significantly. Some instruments and all heat transfer surfaces must be wet in order to operate efficiently. To achieve wetting, heat to at least $600^{\circ} \mathrm{F}\left(316^{\circ} \mathrm{C}\right)$ for 24 hours as a minimum. A better procedure is $1000^{\circ} \mathrm{F}\left(538^{\circ} \mathrm{C}\right)$ for 24 hours, but this is not always possible. For instruments or surfaces that must be wet at lower temperatures, less than $60 \mathrm{C}^{\circ} \mathrm{F}\left(316^{\circ} \mathrm{C}\right)$, wetting may be accomplished by depositing a layer of metal (gold or tin for example) on the surface.(10) The metallic layer is soluble in the liquid metal and results in excellent wetting. The concern is to not assume that wetting is going to take place, it must be assured. Cleanliness of the system or component used in the 1 iquid metal will enhance the wetability and maximize liquid metal heat transfer.

\subsection{REMOVAL OF LIQUID METALS FROM COMPONENTS}

It is necessary many times to remove the 1 iquid metal from the: surface after removal of equipment from a system. Since the licluid metals are not compatible with water, special processes ara required to handle them. Liquid lead and bismuth are exceptions since they do not react with water in the same way as do the alkali metals. Reference to the accompanying tables suggests many ways in which this may be accomplished (see Fic̣ures 19 and 20 ). 


\title{
CONTAINMENT VOLUMES
}

\author{
OBJECTIVE: IN THE EVENT OF A SPILL/RUPTURE. \\ CONTAIN TOTAL VOLUME. \\ GOAL: $\quad 1.5 \times$ TOTAL VOLUME
}

LIQUID METAL TANK

VOL $X \mathrm{ft}^{3}$
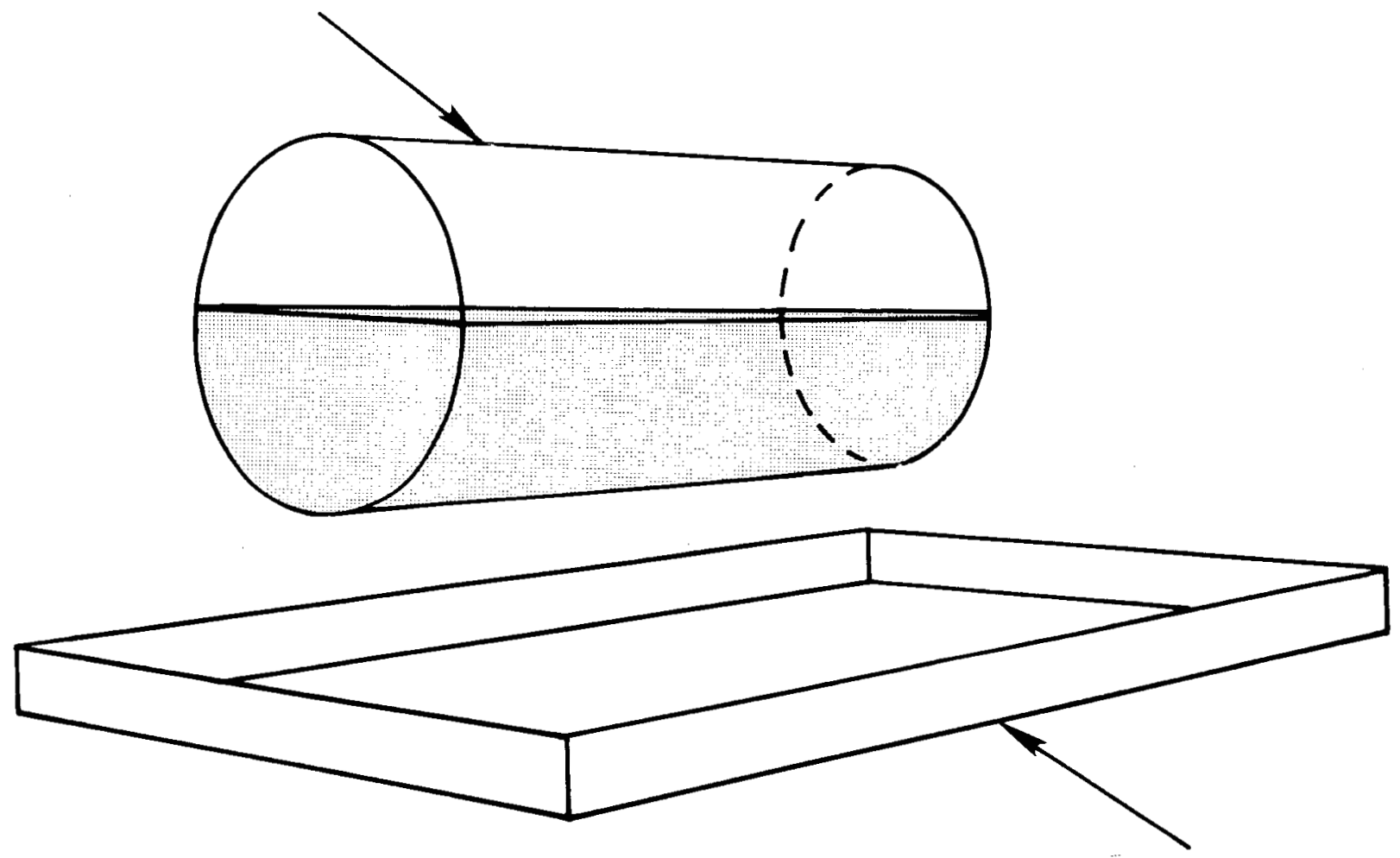

CATCH PAN VOL. $1.5 \times \mathrm{V}$. (OR COVERED SUMP)

FIGURE 11 


\section{DESIGN GUIDELINES}

OPENINGS \& PENETRATIONS:

\section{(ALL OPENINGS FROM TOP)}

A. MANHOLES, ACCESS

OPENINGS (TOP ONLY)

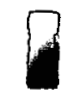

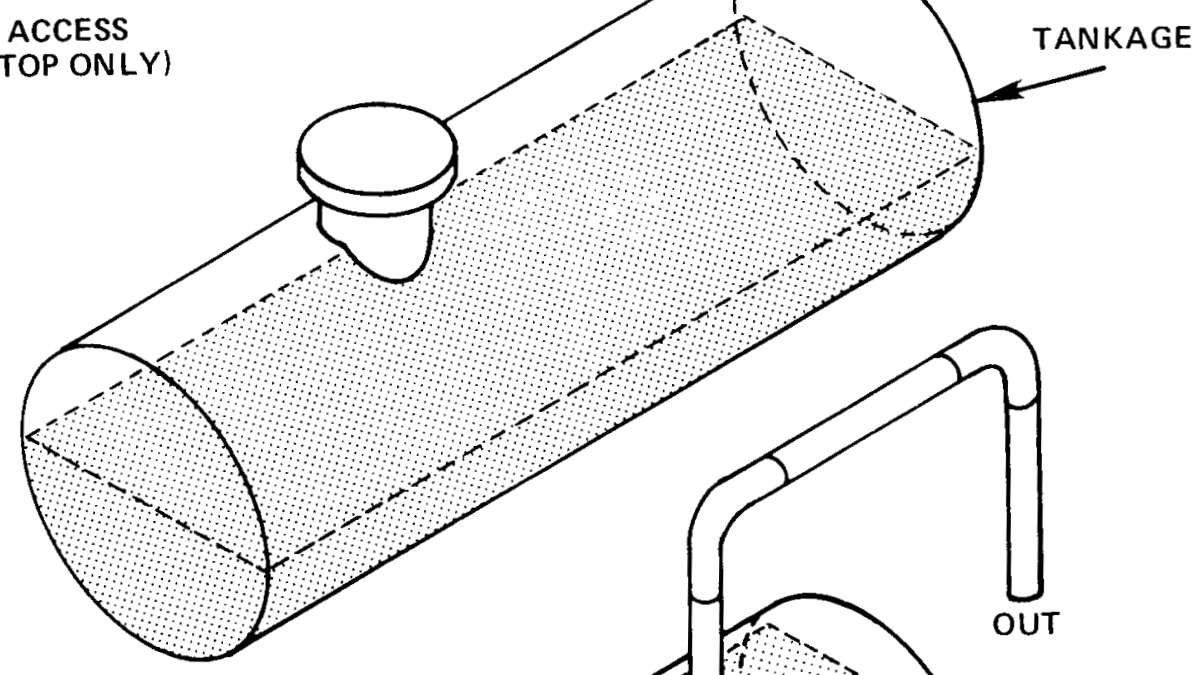

7

B. PIPE CONNECTIONS
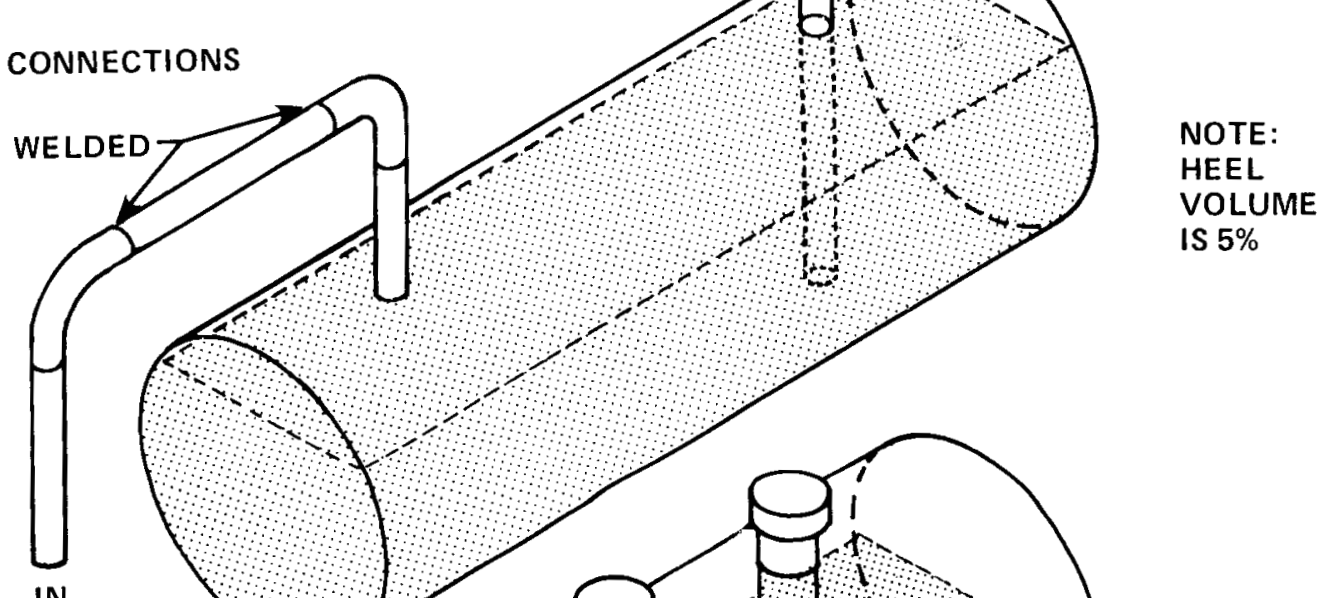

IN

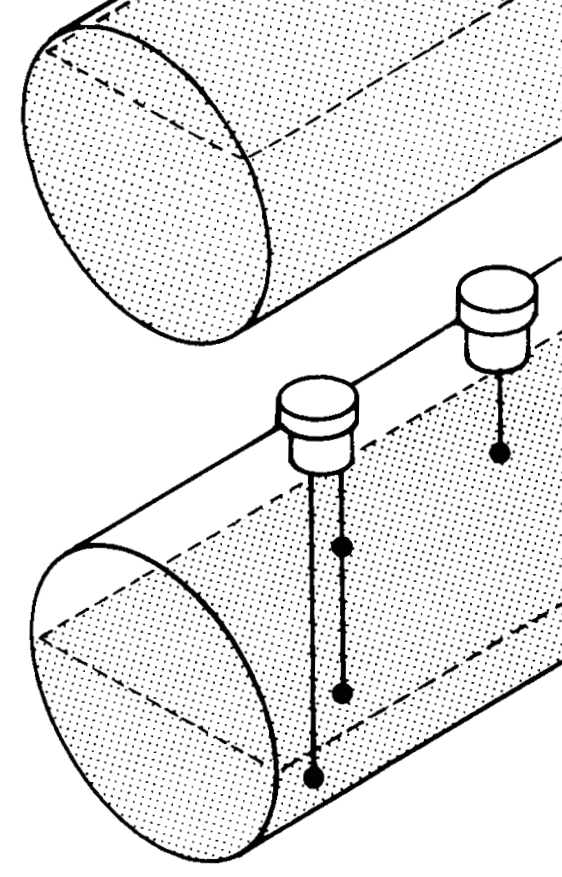

FIGURE 12 


\section{TANK HEATING}

SCHEMATIC OF TRACE HEATING

$\&$ INSULATION OF A TANK USED

TO HOUSE LIQUID METALS.
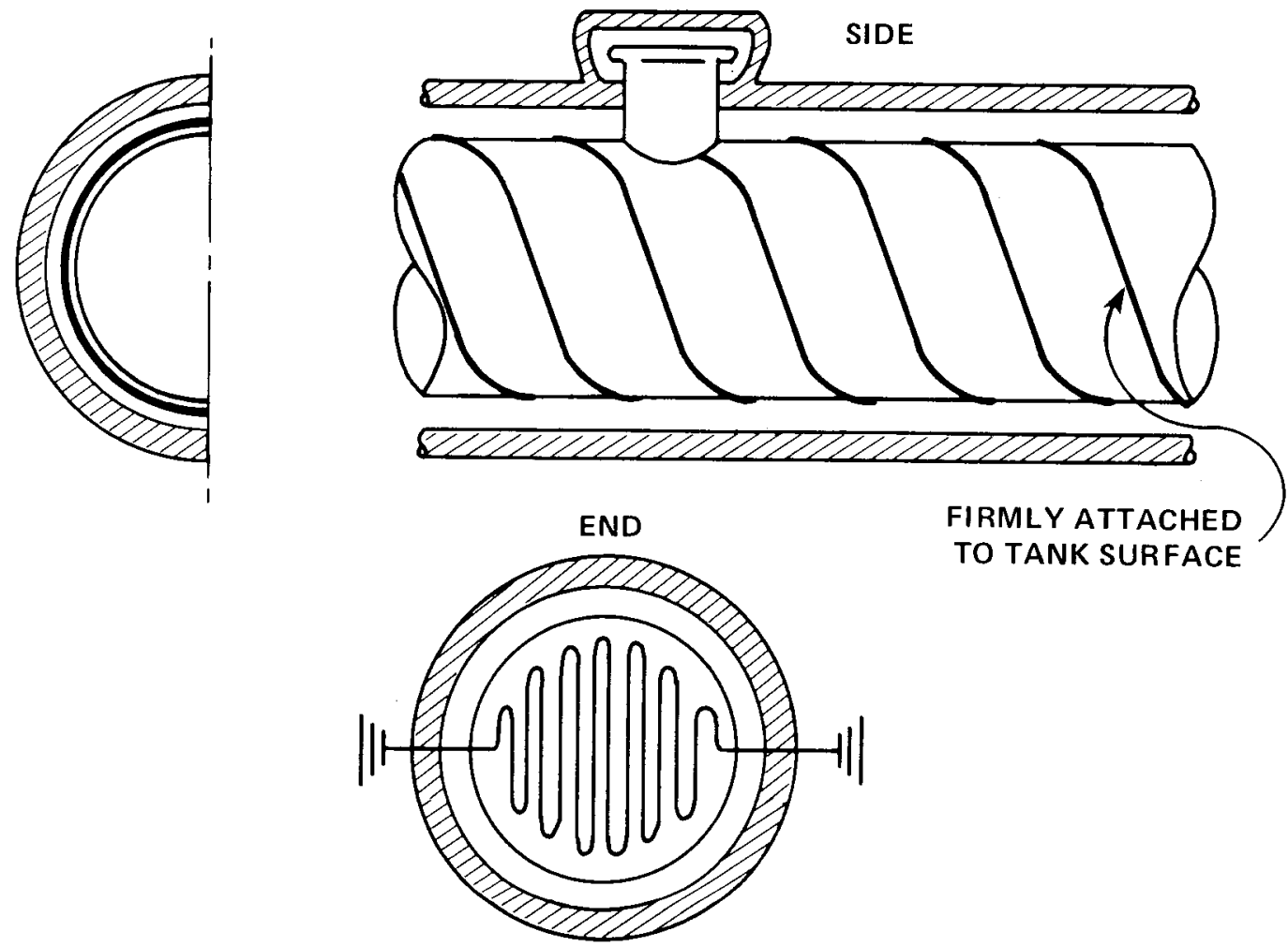

TO TANK SURFACE

NOTE: OF THE LIQUID METALS GENERALLY USED, ( $\mathrm{Na}, \mathrm{Nak}, \mathrm{Li}$ ) ONLY NaK IS LIQUID AT ROOM TEMPERATURE. HENCE NEED FOR TRACE HEATING.

GENERALLY DESIGN FOR $500 \mathrm{~F}\left(260^{\circ} \mathrm{C}\right)$

TRACE HEAT SYSTEM CAPABILITY. 


\section{PIPE HEATING}

NOTE: OFTEN THE TRACE HEATING CABLE

IS OVERLAID WITH STAINLESS STEEL FOIL

( 1 MIL THICK) TO ACT AS AN ENCLOSURE

TO THE HEATING COILS. THE INSULATION

IS APPLIED ON TOP OF THAT.

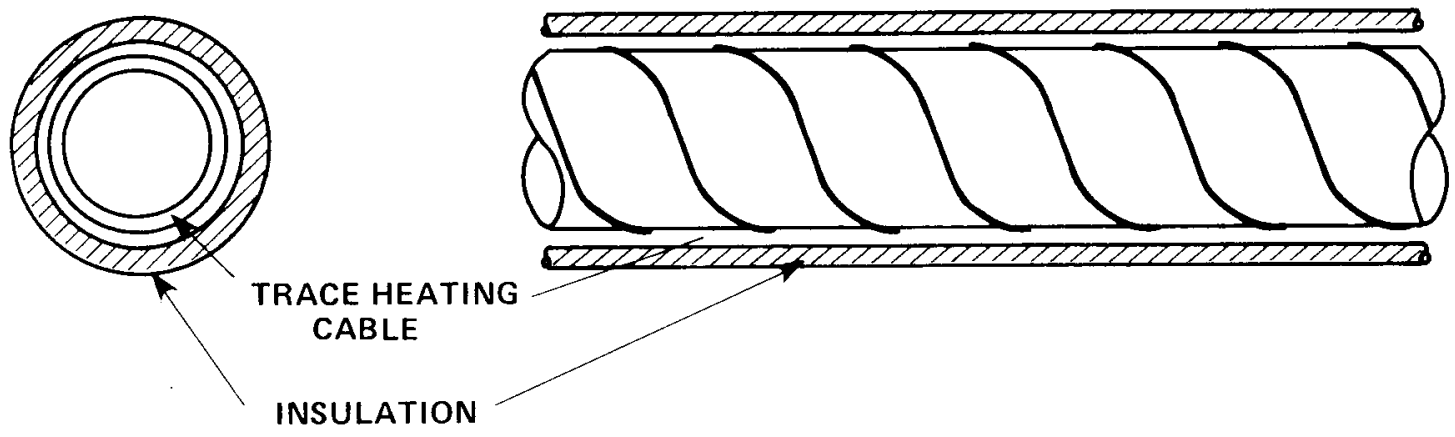

\section{VALVES}

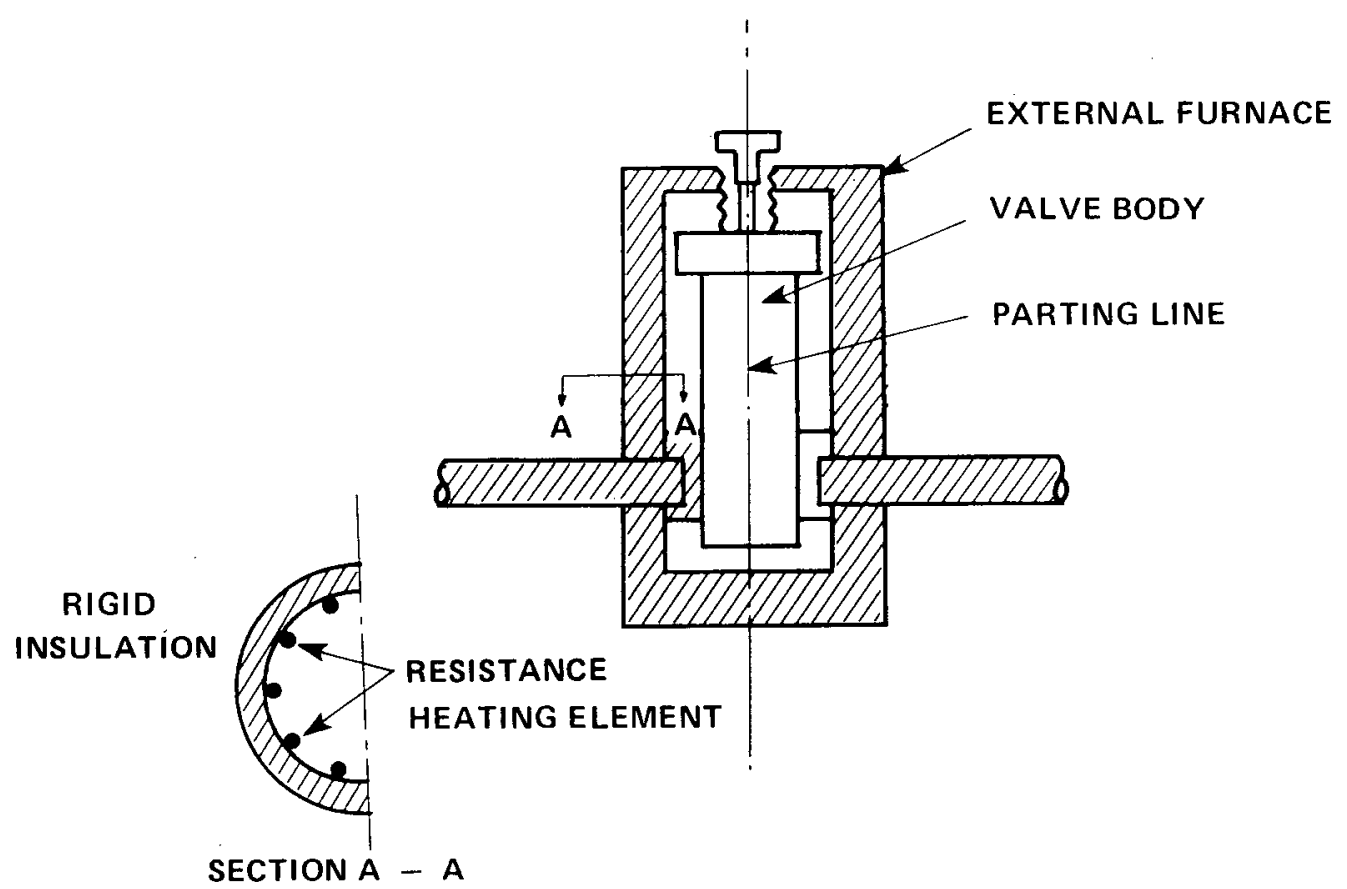

REFERENCE 1

FIGURE 14 


\section{TYPICAL PRE-HEATER AND INSULATION ASSEMBLY}

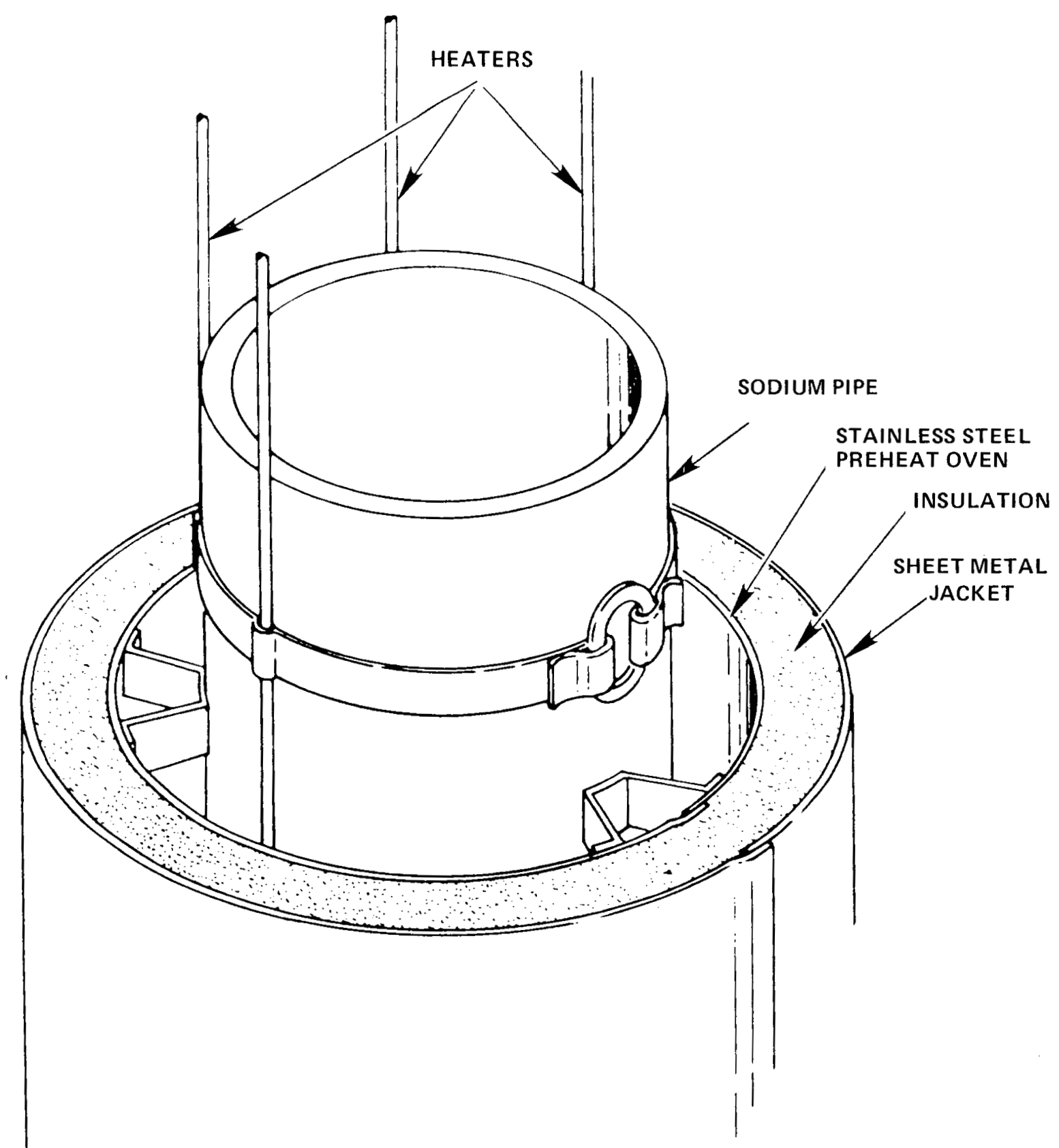

REFERENCE 1

\section{FIGURE 15}




\section{PREHEAT AND INSULATION SYSTEM}

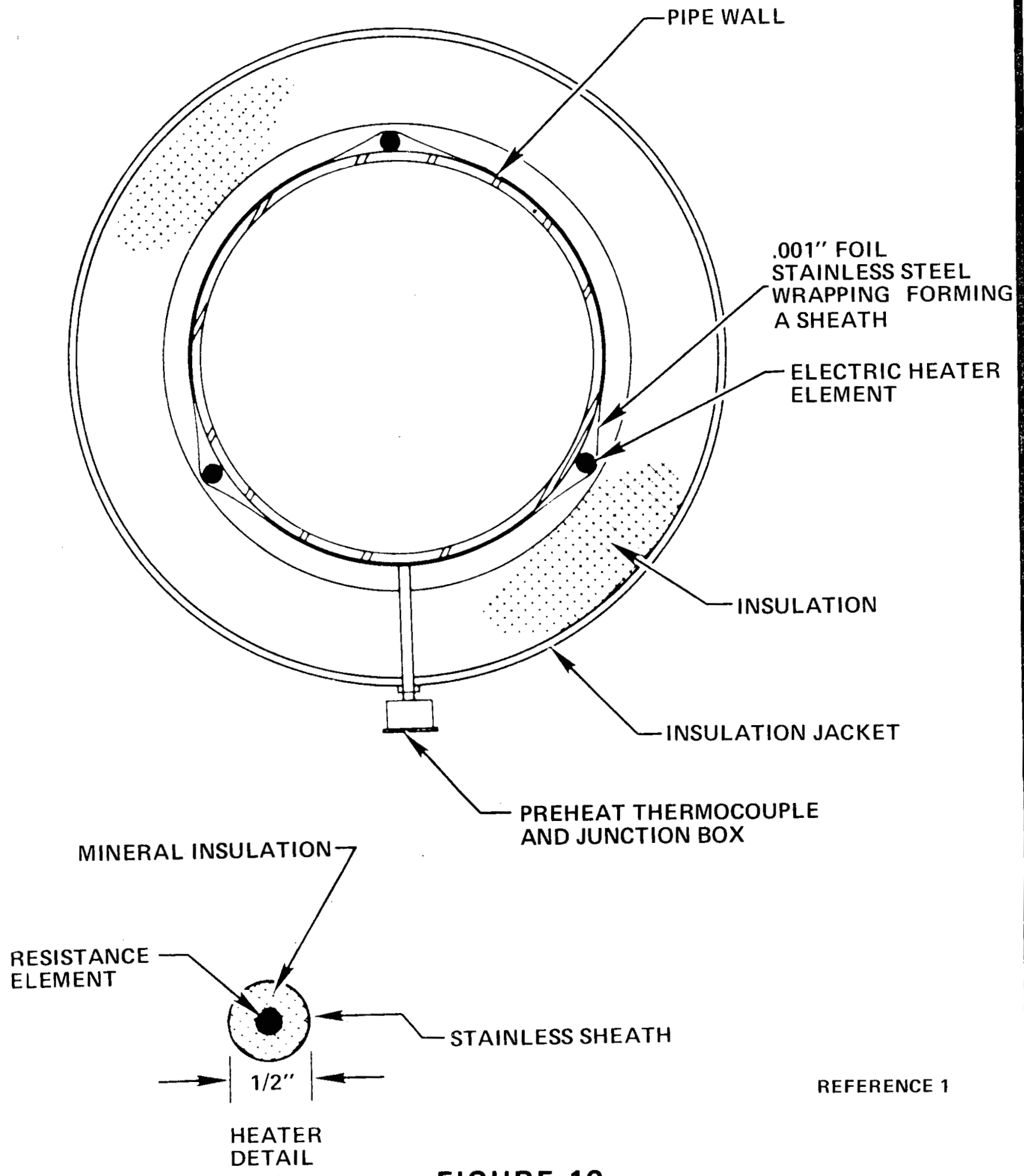

FIGURE 16 


\title{
SYSTEM DESIGN TO CONTAIN SODIUM
}

\author{
- all welded construction used \\ IF POSSIBLE \\ - WELDED MANHOLES USED IF POSSIBLE \\ - INSTRUMENTS - SPECIAL DESIGN WITH NO \\ ENVELOPE PENETRATIONS WHERE POSSIBLE \\ - WHERE POSSIBLE, OPENINGS ARE IN \\ GAS SPACE \\ - FREEZE SEALS USED WHERE APPLICABLE \\ - TANK OPENINGS ON TOP OR SIDE OF \\ VESSEL
}




\section{SODIUM SYSTEM SCHEMATIC}

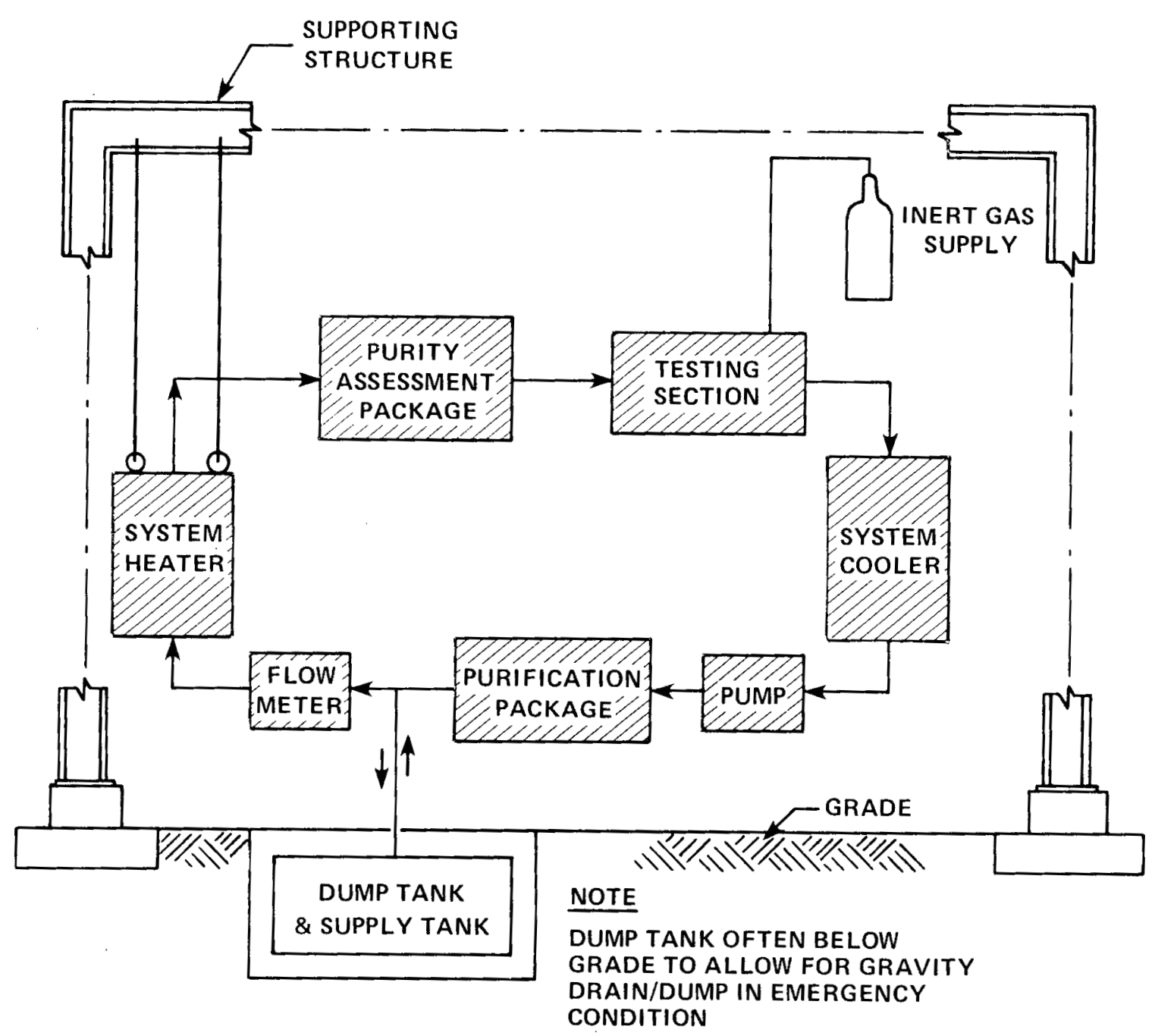

OFTEN BEST FIGHTING STRATEGY IS TO DUMP SYSTEM \& HEATER POWER, SHUT OFF HEATER TO MINIMIZE SPILL, IF OTHER PARTS OF SYSTEM ARE BREECHED. HOWEVER-FREEZE OFF OF SECTIONS AND CATCH PANS OR SELF EXTINGUISHING SUMPS ARE SECOND LINE OF DEFENSE. 


\section{SODIUM REMOVAL REAGENTS}

METHOD USE SELECTION TABLE

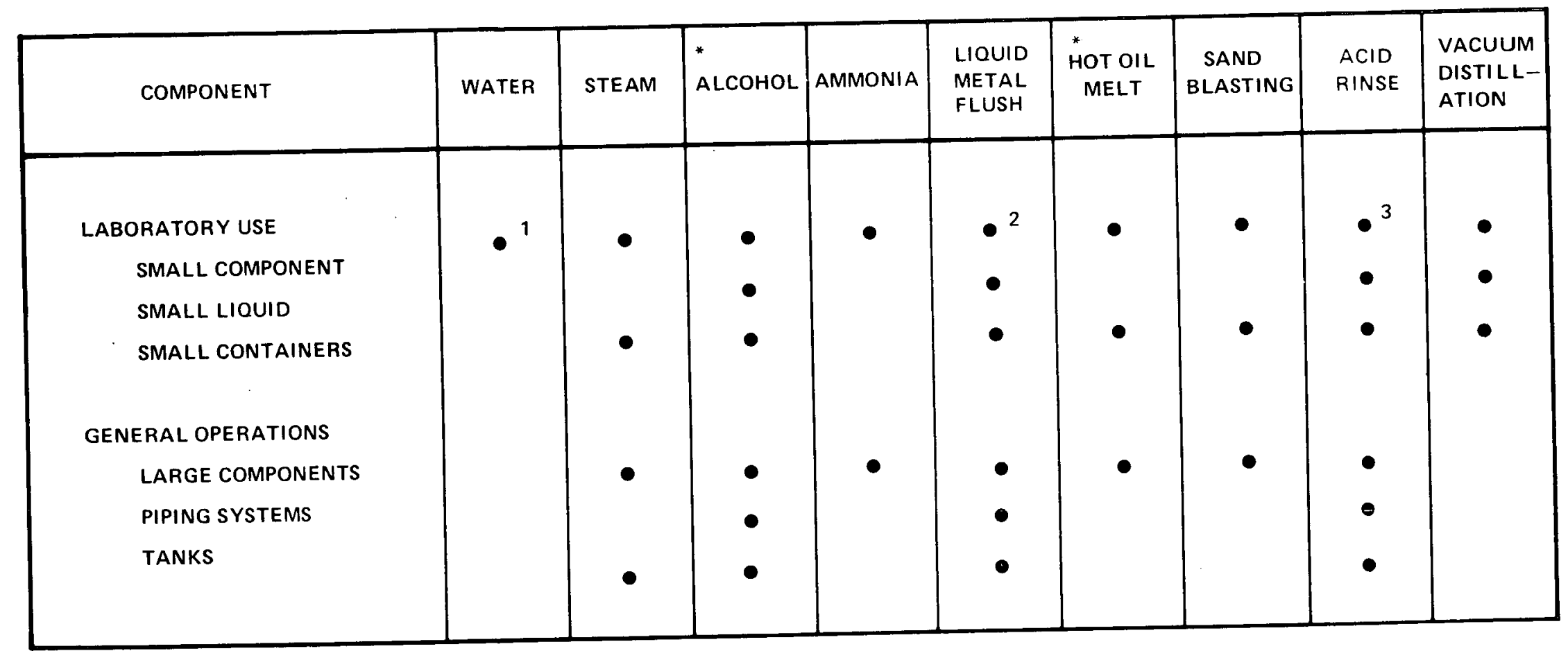

1. GENERAL RINSING IN MOST ALL CASES

*FIRE CONSIDERATIONS

2. GENERALLY A PRE-CLEANING

3. MOST OFTEN USED FOR R/A DECONTAMINATION AFTER NA REMOVAL 
5.0 SYSTEM CONSIDERATIONS IN THE USE OF LIQUID METALS

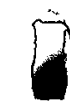

8

3

I

L

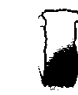

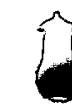

7

$\hat{b}$

9

?

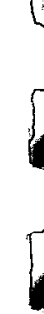




\subsection{SYSTEM CONSIDERATIONS IN THE USE OF LIQUID METALS}

\subsection{CODES AND STANDARDS}

Review of the fire control specifications(ll) proposed for use in light water reactors suggests that many concerns are cominon to nuclear systems and normal industrial practice. Radioactivity and the resulting need to maintain radiological boundaries or containment integrity is the main theme. Differences between the light water and the liquid metal cooled reactors are noted in the accompanying table (see Figure 2l). The two dimensions added in the liquid metal reactor are sodium preisence and use of inert atmospheres. Since burning sodium cannot be treated with water, it is necessary to use special extinguishing agents.

In current National Fire Protection Association (NFPA) codes, (12) nuclear reactors are generically dealt with at length. Outside of the conventional approaches, one thing stands out. The greatest fire problems come not from the completed reactor complex, but in the construction phase of the project. This results from the large quantity of flaminable construction inaterial used during construction operations. Thus, fire control is vital from start to finish. All codes likewise emphasize the system operational phase training in procedures necessary for day-to-day operation.

In the National Fire Codes (NFPA 802), the matter of 1 iquid metals is barely mentioned. Standard 802 talks about LMFBR's but without going into detail. It was also noted that no section was included in the National Fire Codes covering inert gas deluge other than $\mathrm{CO}_{2}$ as a means of fire protection. The section on $\mathrm{CO}_{2}$ (NFPA 12) covers some of the same items, but is specific to the characteristics of that gas.

Likewise, NFPA $72 \mathrm{E}$ was examined on detectors. This is an excellent section on the use of the detectors. It provides valuable guidance, particularly in the appendix, on applying these devices.

The new draft NFPA Standard 803-1977(13) has also been reviewed. This is an excellent source for reactors in general, but it is nearly silent on the problems of 1 iquid metals. It decils with them in regulation $1-4.5$ which 1 ists suggestions for gocid practice.

The matter of space ventilation or, more specifically, venting of areas where you are introducing the 1 iquid metal and subsequently quenching these in a fire situation with inert gaises is not covered in existing NFPA codes. This apparently is also out of the scope of the air conditioning and ventilation po:tion of the standards under NFPA section 90A. This code mentions free venting area, but is silent on the specifics of the inerting problem. 
Liquid metal cooled reactor design emphasizes separation of zones where liquid metals are present from other parts of the plant. This allows nonwater fire protection systems to be inst:alled where applicable. Most of the reactor systems are conventional for the balance of the plant.

The use of liquid metals presents special fire fighting problems not only in the agents used for extinguishment, but in the visibility of the systems under fire conditions. Sodium, for example, during burning, converts about one-third of its mas: into smoke or fume. This fume is very irritating. It is also very dense and results in near zero visibility. This greztly affects the ability of fire fighters to fight fires by hand. It also requires that special consideration be given to the fume removal and control. The radioactivity of primary sodium must also be dealt with. Fume from sodium will clog and henze overload conventional high efficiency particulate filters (HEPA) if not preceded by some type of pre-filter or collecting device to decrease the volume of material. In tandem with pretreating systems, HEPA filters can do a very creditable job.

If the fume carries throughout the building, special prcblems arise. The fume at very low humidity settles as a dust. It can be removed by a vacuum cleaner, and though it is sometimes irritating to the operator, it is a routine operation. However, presence of moisture results in a layer of socium hydroxide. This makes operations difficult because everything becomes slick and difficult to handle. The hydroxide prcduct is also corrosive to most metals. It is particularly hard on electrical systems components such as relays and cortacts.

For the purposes of description, two types of 1 iquid metal systems will be discussed. The first, a sodium system, is represented by component test rigs which are generally without racioactivity. The second is the reactor system where there is raclioactivity present. The principles of fire control engineering are applicable to both radioactive and nonradioactive syistems. The preliminary discussion, however, deals with nonradioactive systems.

\subsection{FIRE CONTROL ENGINEERING FOR NON-RADIOACTIVE RIGS}

\subsection{Isolation (Separation)}

The first principle of systems design for control of fire is isolation or separation. Since rigs are for the most part placed in buildings with other systems, the fire risk can be reluced by isolating a system as much as possible in the building housing it. This is accomplished by physical isolation 
using distance or by the enclosure of the rig in a metal housing. The housing has several functions. First, limitation of personal access as a safety feature. Second, the containment of the fume and facilitation of fire detection. The confined fune acts as a means of detection of a malfunction which often results in a leak. The metal housing provides the enclosure to coniey the fume to a scrubber or appropriate fume handing system allowing safe discharge to the environment. General applications use a metal frame work covered with sheet metal to make a tight configuration. The opening of the doors disconnects the power so that personnel access for maintenance can be accomplished more safely.

\subsubsection{Compartmentation}

The second principle of system design in fire control engineering is compartmentation. As the rigs become very large to accommodate full size components for test, the total system becomes larger than can be easily contained in a single sheet metal enclosure. In these cases, rig sections considered highest risk are contained separately or compartmented. Likewise, the sodium supply and dump tanks are placed apart from the other parts of the system. The smaller size (volume) compartments, lend themselves to better fire control. Compartments are often isolated by dampers or vents that are closed automatically by the leak detection system upon discovery of a fire in that section (see Figures 22 through 26 ).

\subsubsection{Requirement of Non-Water Fire Control}

The third principle of system design is the recognition that liquid metal fires cannot usually be controlled by hand methods, hence the need for remote application of agents to extinguish the fire or eliminate the oxygen. This leads to the use of inert gases such as nitrogen, argon or helium. In many cases, system design considers the provision of drainage or dumping of the system in the event of a system problem. Hence, the scram of the system means the dumping of the liguid metal back into holding tanks below grade, or the minimization of the presence of the liquid metal where it could leak. However, if there is a problem in the piping system, dumping is not always possible. Therefore, handing of the conditions where this takes place is accomplished by a cool down of the piping system through an automatic power cutoff, hence, loss of heat. A scram results in the following three basic actions: (1) dump (where possible), (2) power cutoff which results in a cool down, ano (3) automatic application of inerting gases or the actuation of a fume control system.

To accommodate the dumping and drainage of a system, all the: pipework is sloped to allow gravity to drain as much of the system as possible. The general concensus is that $1 / 8$ to $1 / \mathrm{L}$ inch per foot $(10-20 \mathrm{~mm} / \mathrm{m})$ is necessary to accomplish dréinage. 


\subsubsection{Liquid Metal Catch Pans (Sumps) and Concrete Protection}

The fourth principle of fire control engineering is the provision of catch basins or sumps in the floor space under the rig or in the compartmented areas for the holding of the liquid metal. The volume of these catch basins should be in excess of 100 : of the volume of the liquid metal contained in the system ovechead. The general rule of thumb is from $125 \%$ to $150 \%$ of the contained volume. This handles the liquid metal as well as the oxide products generated and allows for the volume increase of products and for the tendency of burning liquid metals to "crawl" or climb the enclosure wall by capillary action. Some catzh basins or pans also provide inerting or fire extinguishing agents in the space over the liquid metal holding area.

A corollary to the fourth principle is the fact that 1 iquid metals and concrete are incompatible. Contact can cause extensive damage to the concrete both on the surface and in its matrix. Concrete is a source of water through its chemical structure. Thus, liquid metals brought in contact with it have the potential for water liberation through the action of heat. Hence the corollary refers to the point that concrete used as a structural member or flooring should be protected by use of metal covering to preserve its integrity and to provide an easy flow path for the Iiquid metal in the event of a spill or leak. The protection of the concrete extends to gutters, or curbs that ar $\epsilon$ used anywhere in the system to limit, divert, or guide flowing materials in the event of a spill. It may also be valuable to calculate the heat loading to see if insulation is required under the metal protection. The mass of liquid metal can allow substantial heat transfer and hence raise the terperature of the concrete to temperatures that result in water bejng liberated. To prevent this, a stand off insulation is necessary to keep the temperature in bounds.

The overall conclusions on the status of technology of socium-concrete reactions, are summarized by Hilliard, et al., as follows: (14)

1. Concrete is reactive with hot sodium (see Figure 2.7). The water in concrete can react either at the $\mathrm{Na}-$ concrete interface, or it can migrate to other areas to react far from the point of origin. Sion and iron oxide are the other two important components of concrete which are reactive with sodium. Sodium must migrate to the reacting site within the concrete matrix in order for these reactions to occur. The solid reaction products tend to form a barrier and 1 imit the rate of reaction unless the concrete is cracked by mechanical or thermal stresses. When cracking occurs, the reaction can propagate rapidly. Large scale testing is required to evaluate the cracking phenomena. 
2. A valid model (in computer code form, WATRE) (17) for estimating the rate of water release from concrete is presently available. A mass transfer model supported by empirical diffusion coefficient data allows realistic predictions of water release rates. It is available through the Argonne National Code Center.

3. Significant quantities of hydrogen can be formed under hypothetical, severe LMFBR accident conditions. The potential for hydrogen formation must be evaluated for each facility configuration. Not all of the water released from concrete necessarily reacts with sodium. It depends upon the specific configuration involyed. High temperature sodium forms $\mathrm{H}_{2}$ on a mole per mole basis. Low temperature sodium reacts to form $\mathrm{NaOH}$ and one half mole of $\mathrm{H}_{2}$. The critical temperature at which each occurs is not known.

4. Properly designed liners and catch pans can be effective in limiting water release, hydrogen formation and concrete damage. Design of liners should consider water release and venting requirements for the design basis accident conditions. A small defect in a cell liner can potentially grow in size due to rapid corrosion by water and its reaction products if exposed to steam and sodium at high temperatures. The corrosion process may cease when the concrete becomes dehydrated and water no longer reaches the liner.

The conclusions drawn by Hanford people from the information available in the literature(17) are that: (1) sodium can potentially react exothermally (evolve heat) with both the water content and some of the solid constituents of concrete, (2) appreciable quantities of hydrogen can be generated by the sodium-water reaction, (3) the hydrogen will burn in air, resulting in flames different from normal liquid metal flame fronts which are usually low lying, (4) the hydrogen gas can accumulate in enclosures with $<58 \quad \mathrm{O}_{2}$ atmosphere, and (5) a scaling effect may exist which requires large full size testing. Insufficient information is available to establish the effects of concrete type, concrete size (surface area and thickness), reinforcing steel, concrete curing time, temperature, time at temperature, and oxygen concentration in the cell atmosphere on the kinetics of the reactions.

Past work suggests that concrete reinforcing materials, such as steel should be protected. Damage at depths of up to four inches $(10 \mathrm{~cm})$ was noted. It was primarily loss of bond from high heat present and differences in the coefficient of expansion. These result in loss of reinforcing strength.

It is often found useful to cover the concrete with layers of sand materials to keep the liquid metal from over- 
heating it.(14) However, sand or vermiculite must be protected from direct contact with the liquid metal.

\section{$5.3 . j$ Fire Detection Depends on Instruments}

The fifth principle of fire control, leak detection, depends on instruments and early detection is imperative. Leaks or spills are not normally visible to the naked eye. This results from the covering of trace heating equipment and the insulation necessary to operate the system at high temperatures. It should be noted that the $r i g$ is also in an enclosure and often operates unattended for long periods. This mears that leak or fire detection and location is largely a matter of the instrumentation available to the engineer and his ingenuity in application. In any event, a signal of a problem will inaugurate action (e.g., system shutdown). Most of the rigs seen today run unattended during part of the shift and hence have programmed automatic reaction to emergency conclitions. It is an obvious corollary that all control systems must be reliable and effective. Liquid level indication instiruments play an important role in bench marking leak effects. Figure 28 shows two common types. $(2,15)$

\subsubsection{Instrumentation and Control Redundancy}

The sixth principle of fire control engineering design is the need for redundancy in systems for control sensing or heating. This is necessary because systems cannot be easjly maintained due to inaccessibility and hence the need for rellability is high. This is particularly necessary where the volume of the liquid metal inventory is high and hence a greater risk of damage or fire loss is possible. This can be accomplished by putting two heater systems or temperature indicators on at the same time. When one goes out, using the second prevents premature system shutdown for repair or maintenance.

\subsubsection{Fume Control}

The seventh principle of fire control engineering relates to the handing of the fume. This can be accomplished in the nonradioactive rig operation by conventional ventilating and scrubbing equipment. It likewise provides a controlled discharge that meets local air quality requirements. The motivation to eliminate fume comes from its irritation to people, the potential damage to equipment and the need for visibility in the area as well as stringent effluent release requirements. 


\section{SYSTEM DIFFRENCES FROM FIRE CONTROL STANDPOINT}

\begin{tabular}{|c|c|}
\hline LIGHT WATER REACTORS & LIQUID METAL REACTORS \\
\hline CONVENTIONAL FIRE FIGHTING & $\begin{array}{l}\text { CONVENTIONAL IN AUX. BLDGS } \\
\text { SPECIAL IN SODIUM AREAS } \\
\text { (NO WATER ALLOWED) }\end{array}$ \\
\hline HIGH PRESSURE IN REACTOR & GENERALLY LOW PRESSURE IN REACTOR \\
\hline $\begin{array}{l}\text { CONVENTIONAL SYSTEM } \\
\text { CLEANUP \& DISPOSAL }\end{array}$ & $\begin{array}{l}\text { SPECIAL PROBLEMS IN SYSTEM } \\
\text { CLEANUP \& DEBRIS DISPOSAL }\end{array}$ \\
\hline $\begin{array}{l}\text { CONVENTIONAL STRUCTURES } \\
\text { DESIGN FOR COMPARTMENTIZATION }\end{array}$ & $\begin{array}{l}\text { CONVENTIONAL STRUCTURE DESIGN } \\
\text { FOR COMPARTMENTIZATION } \\
\text { BUT USE OF CURBS/GUTTERS } \\
\text { FOR CONTAINMENT }\end{array}$ \\
\hline CONVENTIONAL AIR ATMOSPHERES & $\begin{array}{c}\text { CONVENTIONAL EXCEPT SODIUM } \\
\text { AREAS - PRIMARY IS SECONDARY INERTED } \\
\text { IN EMERGENCY }\end{array}$ \\
\hline CONVENTIONAL SMOKE PRESENCE & $\begin{array}{c}\text { CONVENTIONAL \& HIGH FUME CONTROL } \\
\text { (VERY LOW VISIBILITY \& INABILITY TO } \\
\text { WORK FIRE IN) WITH SODIUM }\end{array}$ \\
\hline
\end{tabular}

FIGURE 21 


\section{COMPARTMENTATION}
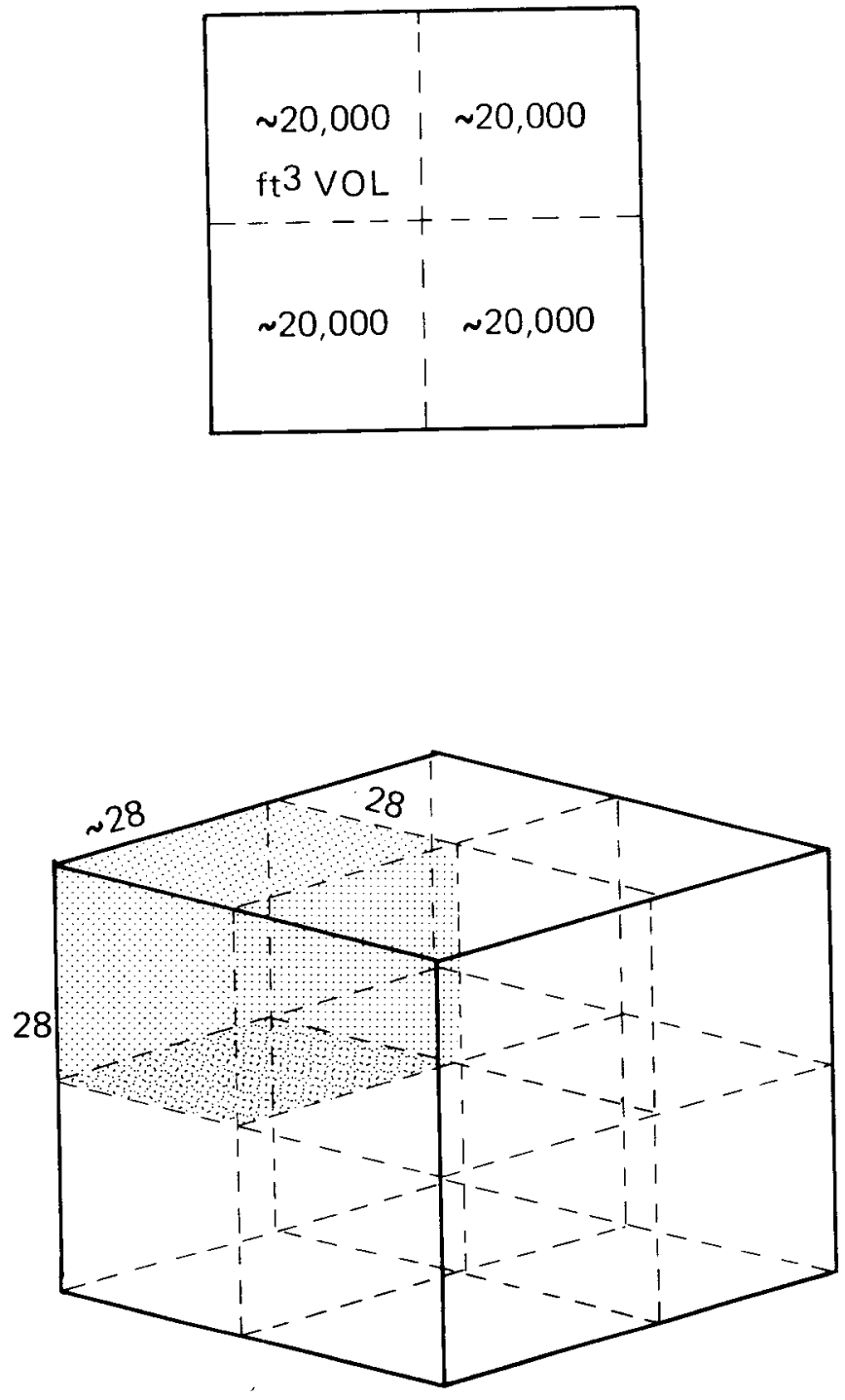

COMPARTMENTATION:

OBJECTIVE: TO REDUCE FIRE AFFECTED AREA.

GOAL: 20,000 ft3 PER COMPARTMENT. 


\section{REACTOR CONTAINMENT CELL AND VESSEL SNR-300 (GFK) \\ (GERMAN FEDERAL REPUBLIC)}

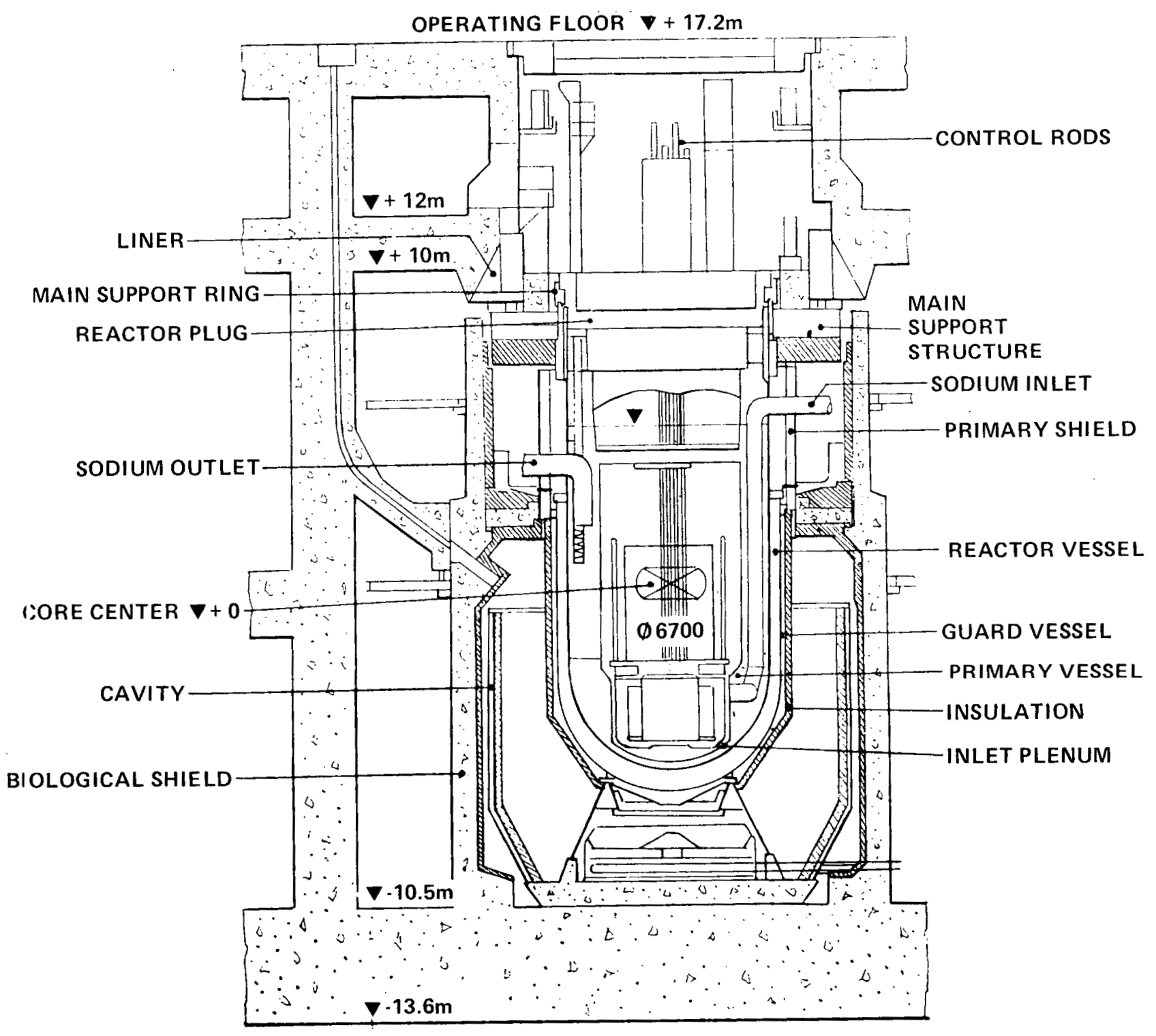

REFERENCE 27

FIGURE 23 


\section{EXAMPLE OF REACTOR COMPARTMENTATION FROM FFTF*}

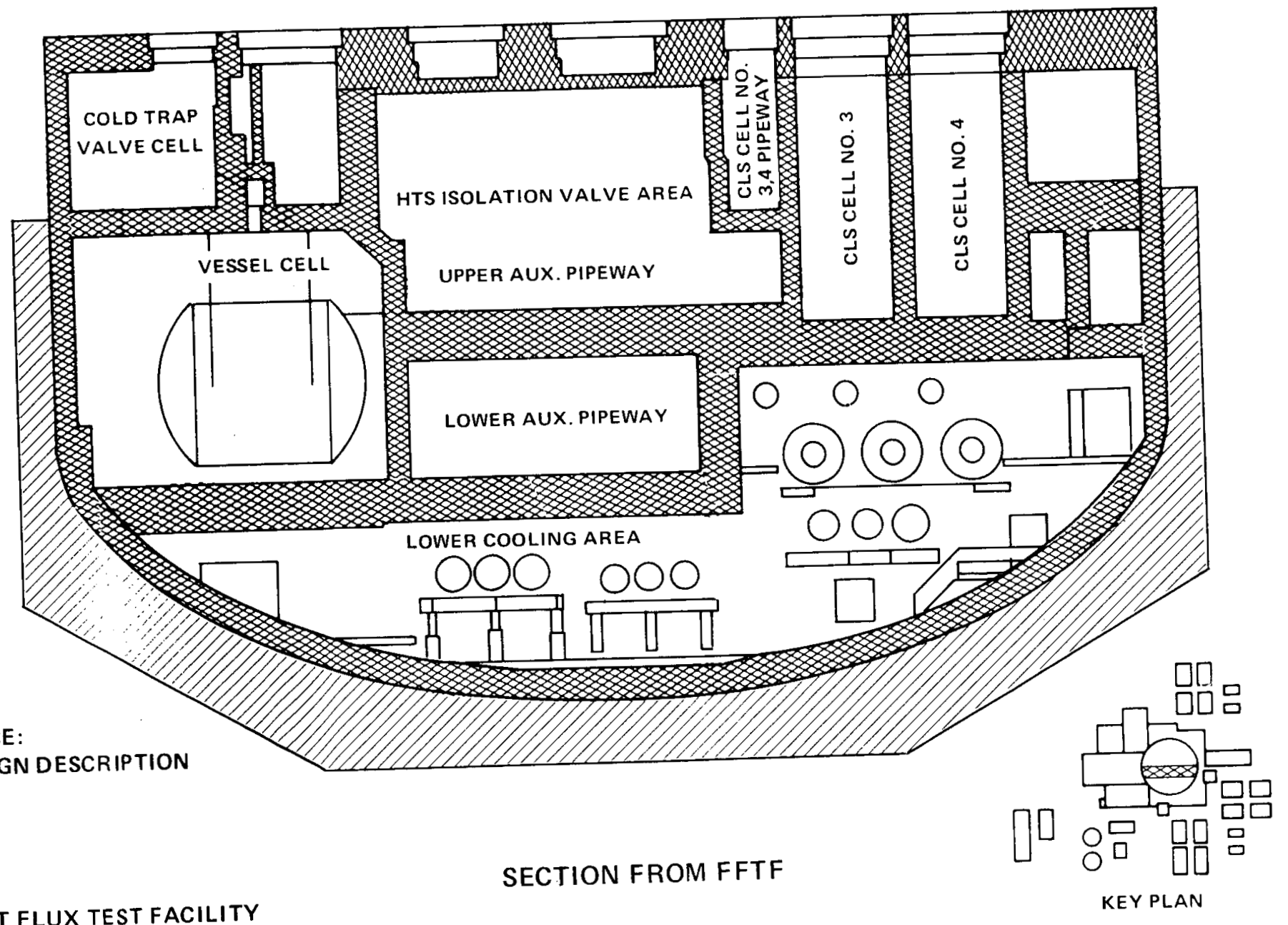

FIGURE 24 


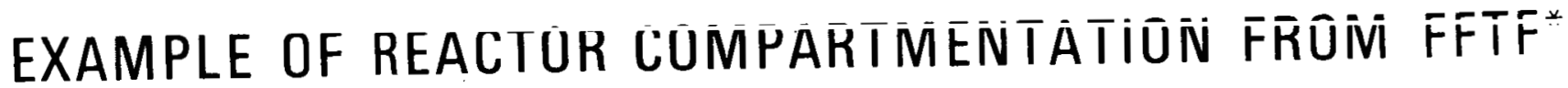

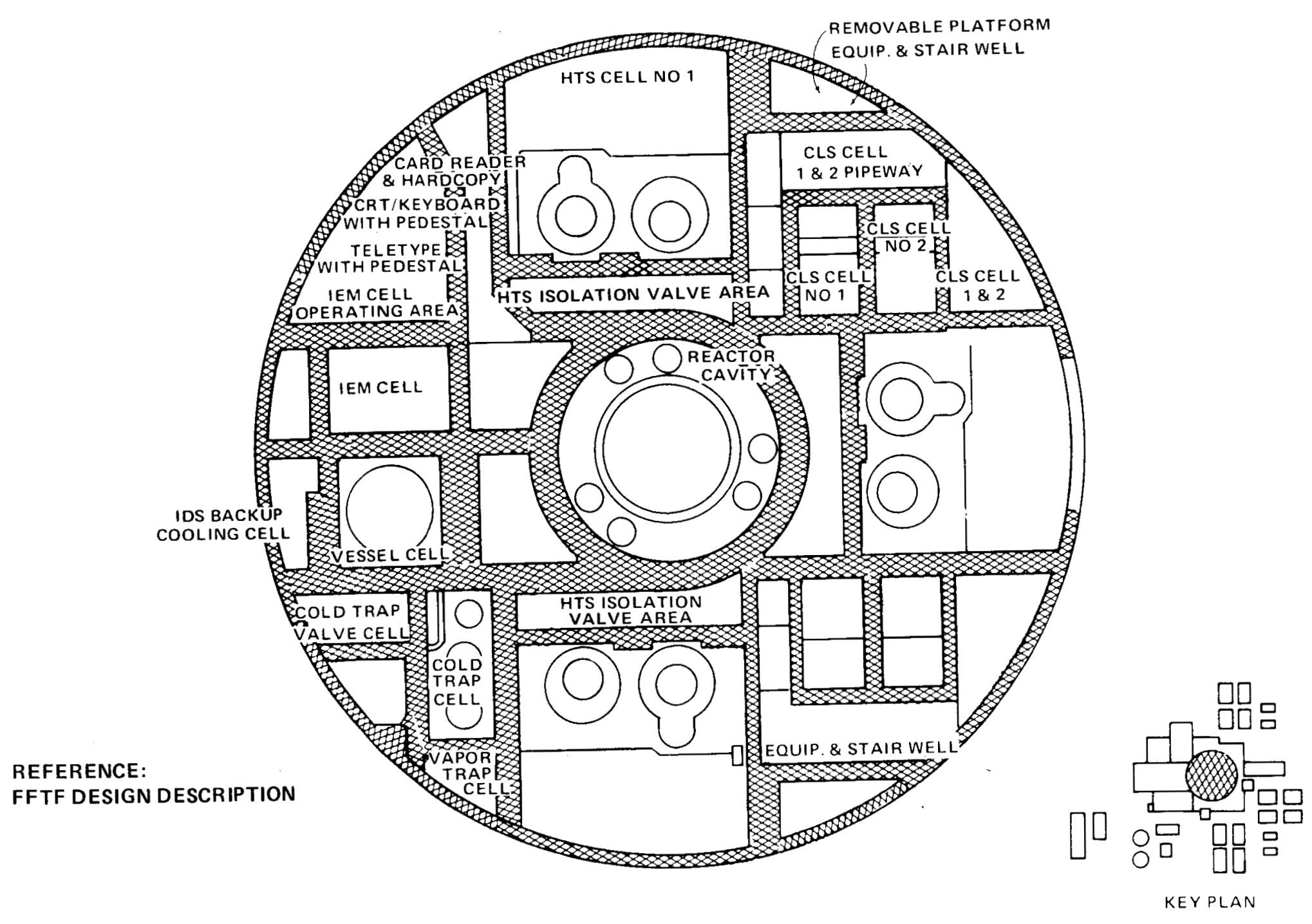

*FAST FLUX TEST FACILITY

PLAN VIEW OF FFTF NEAR REACTOR TOP FIGURE 25 


\section{EXAMPLE OF REACTOR COMPARTMENTATION FROM FFTF*}

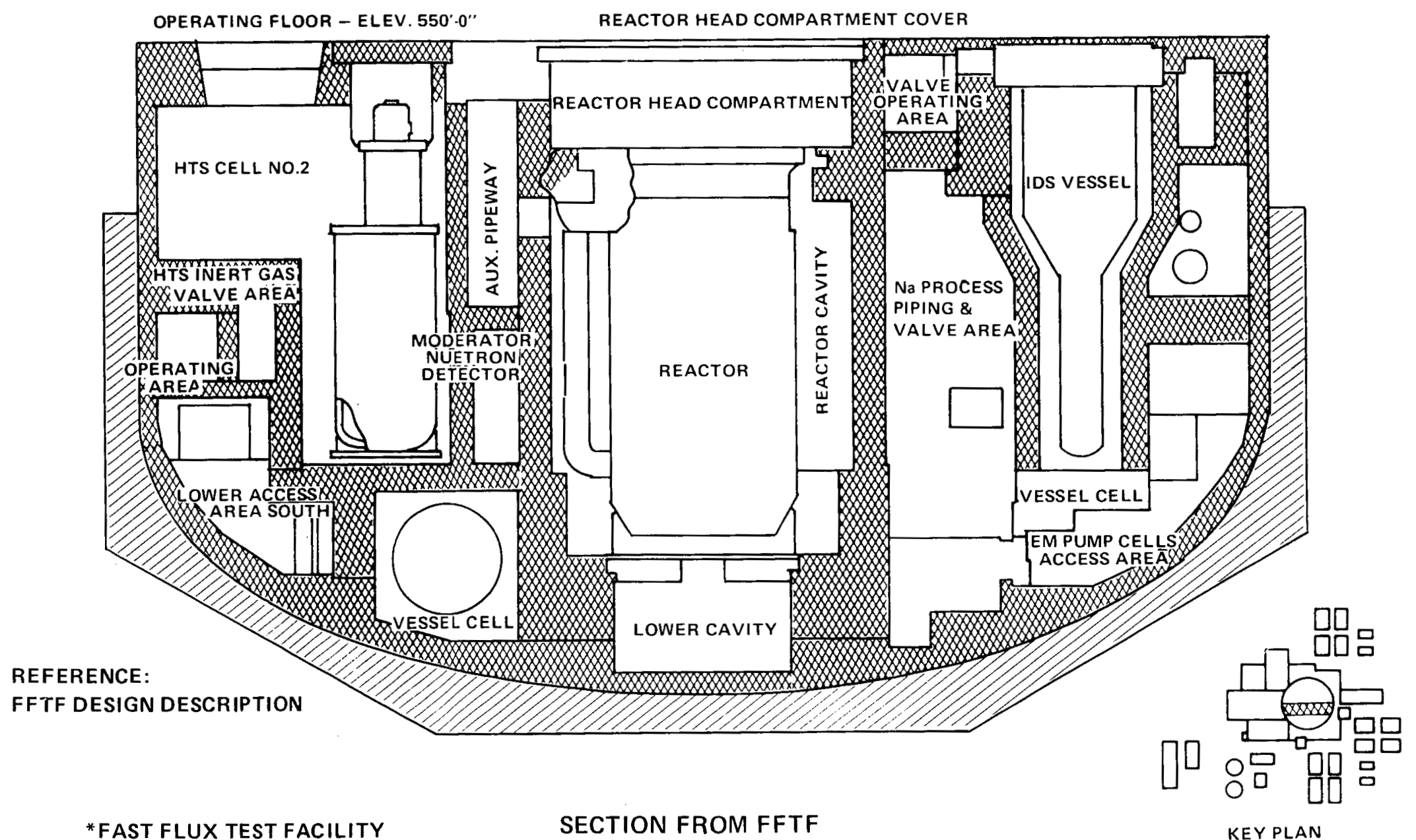

FIGURE 26 


\section{POSSIBLE SODIUM-CONCRETE REACTION EQUATIONS}

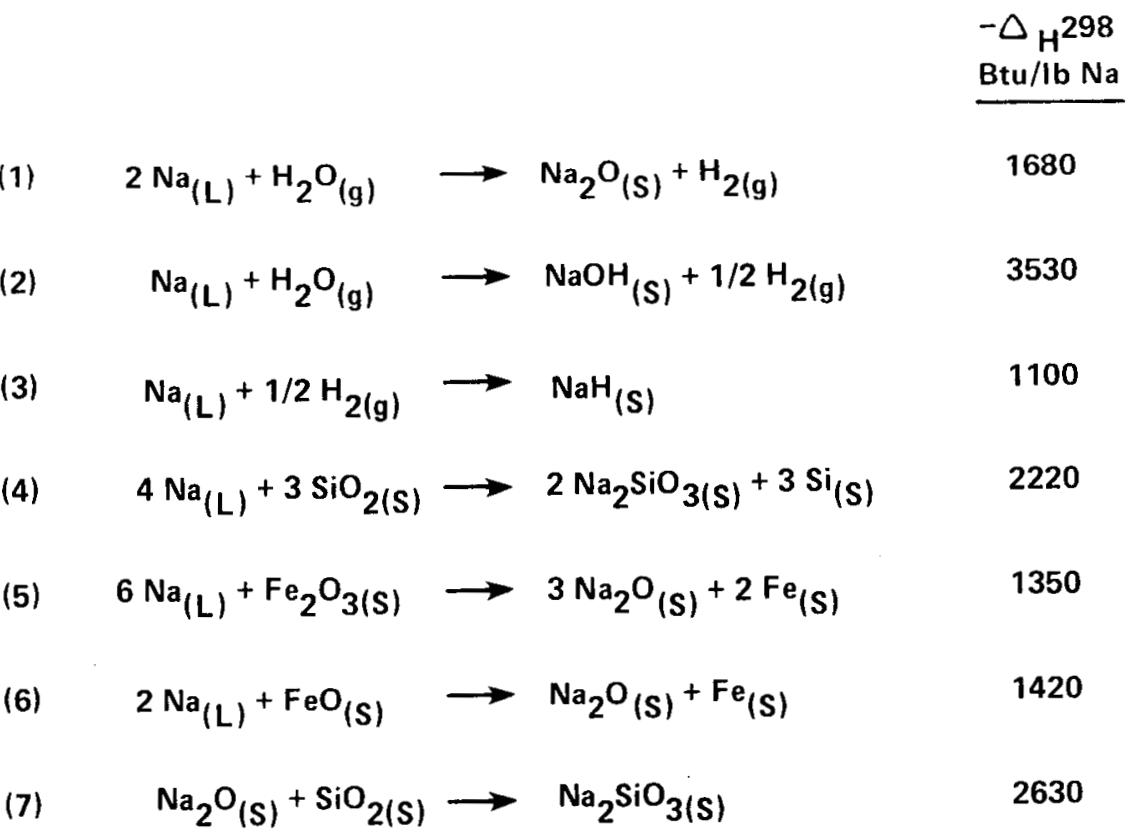




\section{LIQUID LEVEL DEVICES}

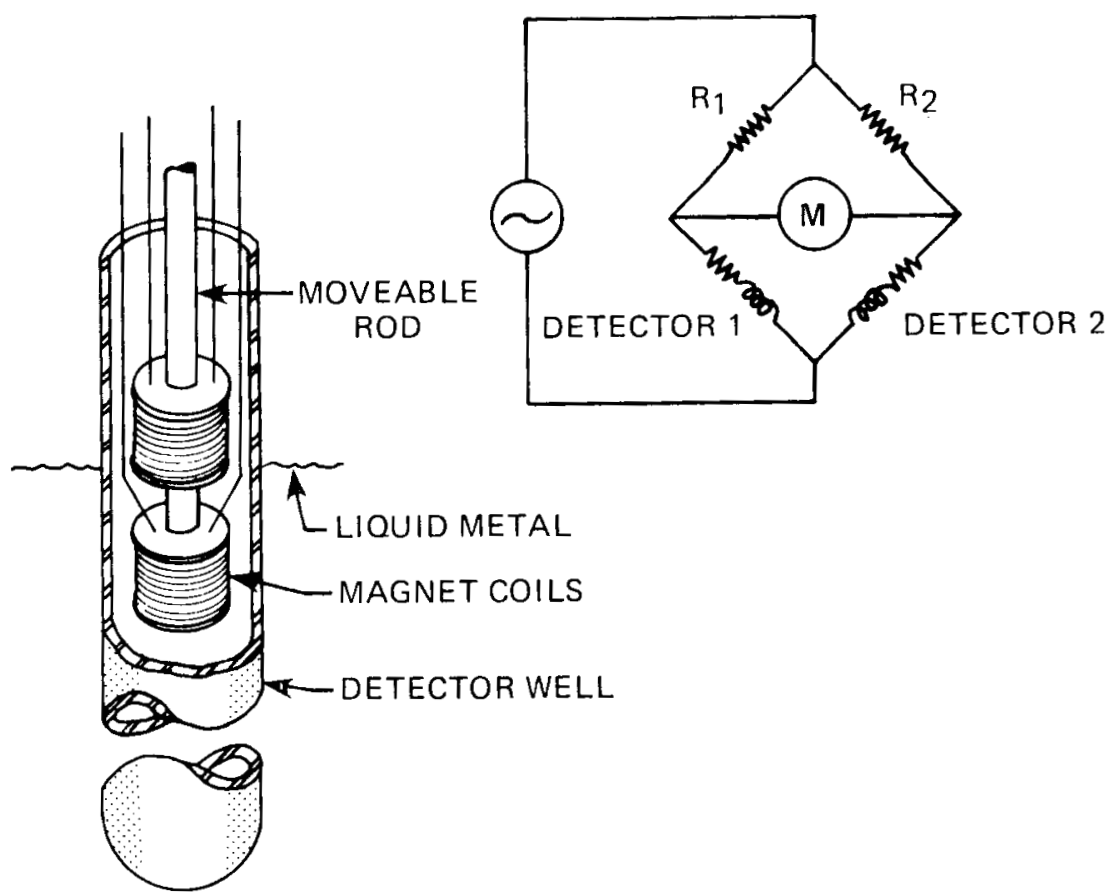

FIG. 7-4. INDUCTION PROBE

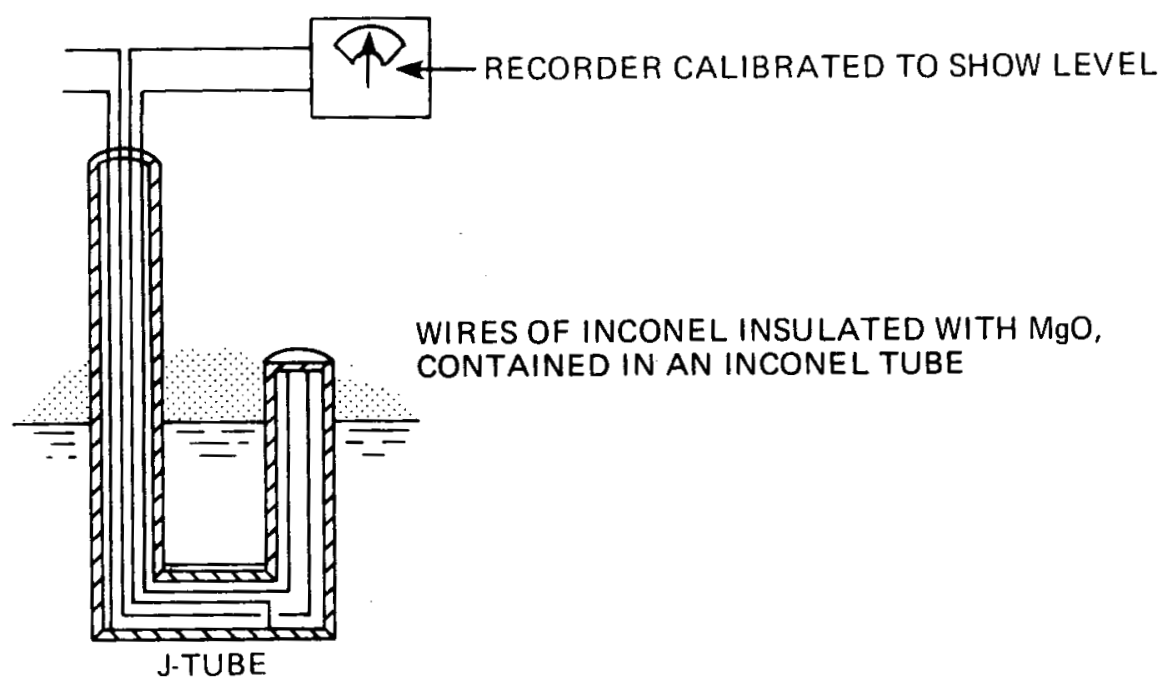

REFERENCE 1

FIG. 7-3. LIQUID-LEVEL DEVICES

FIGURE 28 
The seven principles (Figure 29) enumerated for nonrad:oactive rigs have direct applications to the reactor systiem. The new dimensions are imposed by both radioactive presence and the need for fume control because of its potential for contanination. These restrict the ability of fire people to Eight fires by hand. Hence the need to consider remote application of fire suppressants or imposition of inert atmosphe:res where potential fire hazards exist. Otherwise the appl. ications are the same.

\subsection{NUCLEAR REACTOR DESIGN CONSIDERATIONS}

Fire control engineering must serve in the reactor case to complement the nuclear presence and live with radioactivityrel ated guidelines. First, reactors are basically designed to be safe. They must protect the public and the environs from the spread of radioactivity. The design criteria are the following: conservative design margins, inherent safety features, multiple barriers to fission products, redundant protective systems to prevent accidents, and engineered safety features (see Figure 30).(17) The fire control engineering features are part of the engineered safety features imposed on the system to mitigate and control fires resulting from the use of liquid metals as coolants.

Since the part of the reactor system that handles Iiquid metals is the heat transfer system, reference to Figure 31, (18) gives some view of the configurational safety features that design offers in the fast breeder reactor system. Note the following: (1) Relative positions of components in the system to facilitate coolant drainage back to the core. (2) schemes that prevent the movement of coolant out of critical areas thet require cooling. (3) Compartmentation and lining of the compartments to protect the concrete structures that make up containment. It should also be noted that maintenance of a large reactor poses some interesting fire control problems. It can be illustrated by Figure 32 . (19)

The major ingredient that complicates the reactor design is the presence of $r$ adioactivity. Radioactivity comes from the nurlear reactions with the liquid metal (e.g., Na23 and $\mathrm{Na}^{24}$ ). This in itself 1 imits the closeness that one can come to the coolant system or components during or shortly after opiration. Other components of radioactivity are the activation of corrosion products and the presence of fission products from the fuel materials. The corrosion products are not large in total quantity, but in a Iiquid metal system they are constantly with you. There are limits to the ways to eliminate them in the clused system. Elements such as iron, manganese, and cobalt result from corrosion of the stainless steel containment 
materials. These corrosion products will travel in the system and deposit at either hot or cold spots (on a relative basis) in the heat transport system. The presence of radioactivity means that fire control is most often done remotely. Hence, proper anticipation of the problems and handling them in the facility design takes on a new dimension. This leads to the compartmentation concept and the provision of either a permanent low oxygen atmosphere or means for atmosphere inerting of certain compartments to suppress the fire.

The radioactivity also adds a new dimension in the control of the smoke or fume. In conventional systems, smoke or fume to some: degree can be allowed to enter the environment without control. In the reactor case, the presence of radioactivity requires that all smoke and fume be controlled and processed to remove radioactivity. Removal of radioactivity species is nornally accomplished through the cover gas handling system which diverts the gas through activated charcoal or cryogenic deliy beds to remove active radioactive species for holdup. These are conventional technologies, but have to be designed and sized to accomodate the emergency conditions of the gas handing system.

For purposes of reference, included are the stated requirement:s of fire control and related systems in the Fast Flux Test Facility (FFTF) which state criteria to accomplish fire control in a liquid metal cooled reactor complex. These system desjgn requirements are designer guidelines to be met in the total system design (see Figures 33, 34, 35, 36, 37, 38, 39, $40,41,42$, and 43).(20) Note prime consideration was given to inaintaining the reactor barriers for the control of radioact:vity.

We have included a tabulation of the percent of the nuclear island of the reactor complex that is associated with the liguid metal system for comparison purposes. This table refers to 500 MW FBR system, but serves as a relative measure of cost (see Figure 44).(21) Thus, the 1 iquid metal related segments requiring the special fire control engineering aspect of the reac:tor, represent about one-third of the cost. It is also of interest to note that two types of reactors are considered in the liquid metal designs, the loop, and the pot concepts as seen in ligure $45 .(22)$

\subsection{COMPARTMENT INERTING}

Although the matter of compartment inerting as a means of fire suppression and control has not been discussed in detail, it is appropriate to speak of it in general terms. Radioactivity limits access to cells containing primary heat transfer piping. Hence, in order to supress fires resulting from pipe ruptures some cell areas are constantly kept inert. These are sealed compartments and have specifications for both absolute leak rate and for oxygen quality. They generally 
require concentration of less than 4 or 5 vol o $0_{2}$. Leak rates specified are from 3-5 vol o of the compartment volume leak per 24 hrs e 2 in. of water pressure.(23)

Likewise, some of the other compartments in the nuclear island will have capability to be inerted manually in the event of fire in that area. It is often a matter of preference as to whether it is purposefully inerted manually or as part of :he automatic fire suppression procedure. One factor in that decision is the possibility of the presence of an oxygen deficient atmosphere and its attendant hazard. With manual control, these concerns can often be better handled. An exanple of the areas with capability for gaseous inerting in the FFTF are seen in the accompanying figure (25). One figure (26) also shows the schematic of the manual gaseous inelting system. These figures suggest the extensiveness of the flooding capability. It is noted that in every case there must be the capability to replace the resultant inert atmosphere in order to handle the maintenance, repair, and fire cleanup.

\subsection{FUME HANDLING AND VENTILATION}

The general philosophy of effluent handling in the reactor has evolved over the years. It is presently the policy to redice these effluents to near zero(24) (see Figure 46). This meais that extensive effluent handing systems are incorporated in the nuclear island design. The possible ventilating burden resllting from liquid metals in the event of fires is significant. Remember that in the event of fire, about one-third of the sodium, for example, is converted into a white opague fume or smoke. This is a dense particulate and will overload conventional filter systems rapidly. Explicit handing of the 1 arge volumes resulting is a necessity. French tests(25) sugjest that pre-filter devices such as cyclones will greatly aid the subsequent operation of HEPA filters. Otherwise, the filter loading will render them inoperative in a very short time. In no event will the resulting fume be allowed into the environs without processing to remove radioactive particles through the gas cleanup system. The gas cleanup system must then be sized to accept the large volumes resulting from design base accidents.

Considerable research is still being conducted on an effective means to handle the large volumes of fume resulting from the emergency conditions. The emphasis is now on testing of relatively large quantities of liquid metal and in as near full size configuration as possible. The Hanford Engineering Development Lab (HEDL) in particular has a program to evaluate the means of handling off-gas streams resulting from $1000 \mathrm{Kg}$ (2200 lb) masses of liquid metals spilled and burned in a large test vessel. Results from this ongoing work will provide specific recommendations of means to handle large volumes of fume resulting from energency conditions. 


\subsubsection{Philosophy of Extinguishment Techniques}

Liquid metal fire prevention and extinguishment techniques do not differ in principle from those of conventional fires. The objective is to decrease the temperature of the burning mass by available means. Fire fighting techniques fall into the following categories:

1. Reduction of the oxygen concentration at the gas-liquid metal interface to below the level required to sustain combustion (eliminate the fuel).

2. Increasing the rate of heat loss from the liquid metal to the surroundings until the temperature has decreased below the ignition temperature (cool down the fire mass).

Liquid metal fire prevention and extinguishment techniques can be classified in the following five categories:

1. Full time inert atmosphere enclosures $\left(<5 \frac{8}{8} 0_{2}\right)$.

2. Inert gas deluge of initially air-filled enclosures.

3. Self extinguishment (leave undisturbed to use up available oxygen) in reasonably gas-tight enclosures initially filled with air.

4. Fixed pipe distribution of dry powder extinguishant (still improper technique).

5. Manual application of solid powder by shovel or extinguisher.

Exclusion of oxygen is the chief principle behind each of these techniques, but modifying heat transfer can be effective by transfer of sensible heat to powder extinguishants or structural surfaces. Variation within each of the categories is possible, and the best technique for a given facility depends upon specific conditions such as size of postulated sodium leak, presence of radioactivity, and geometrical size and complexity of the operating facility. Generally, radioactive 1 iquid metals are handled within inerted atmosphere enclosures. However, some small primary sampling and chemistry cells have an air atmosphere to accommodate frequent personnel access.

An important criterion in determining the type of fire protection is the postulated amount of 1 iquid metal leaked. A system and technique which is adequate for controlling small leaks may be totally inadequate for controlling massive spills. A . eak of $>25$ gallons ( looL) of sodium has been arbitrarily suggested as representing large fires.(26) 


\subsubsection{Estimating the Quantity of Liquid Metal Leaked}

The most likely failure of liquid metal containment is at mectanical connections such as valve bellows and seals, flanges, and pumps. Sudden large failure of such fittings is possible, but the probability is much lower than that of a small leak whic:h gradually increases in size. Early detection of such smajl leaks and subsequent corrective action should 1 imit the amount of liquid metal lost.

The amount of liquid metal escaping through a leak point depends on three factors: time, pressure, and geometry of the leal: path. The time during which leakage can occur is limited by perceptive detection devices and prompt operator response. The pressure available as a driving force depends on the system chalacteristics (operating pressure, pump coastdown, pipe size and leak location) and on operator response. The geometry of the leak path can vary from a small hole to a complete pipe rupture with the ends offset by a pipe diameter or more. Estimates can be made of the time and pressure factors, but no rational methods exist for predicting probabilities of leak geonetry. In the absence of engineering information, the provedure is to assume a condition which is believed to give the maximum postulated leak. Suitable consequence-limiting fea:ures are then provided to assure that such accidents can be controlled.

\subsubsection{Extinguishment of Small Fires}

The vast majority of experience with sodium fires has involved <25 gallons of escaped sodium. In fact, most have involved less than one gallon.

The first action taken after detection of any leak is to elininate the source of sodium leakage by reducing pressure, dumping and isolating the leakage point. The problem of leak assessment in piping is illustrated by Figure 47.(27) The actual fire fighting depends on specific conditions, the judgement of the supervising operator, and standard operating procedures. It is important for the operator to be able to assess the size and location of the fire. In some cases, where damage to equipment is believed to be minor, the fire is allowed to burn itself out. In other cases the fire is fought by manual application of dry powder. Large fixed-pipe powder distribution systems normally will not be activated to control small fires because the potential cleanup problems might be more costly than the direct damage caused by small fires.

\subsubsection{Extinguishment of Large Fires}

Large fires will occur in two phases. First, a stream or spray of sodium flows from the break of the pressure boundary. upon contacting oxygen at temperatures above the ignition point 
it vill begin to burn while flowing down vertical surfaces or falling through the air. Whether the sodium emerges as a solid stream or a spray depends on the size of the hole/fracture, the available pressure drop, and presence of semi-retaining structures such as pipe coverings and insulation. In general, the larger the break the greater the quantity of sodium escaping but the less formed as a spray. The second phase of the fire is the pool fire which forms after the sodium reaches the system low point.

The first phase, usually termed the "spray" fire phase, is controllable only by using inerted atmosphere enclosures. In air atmospheres the spray fire will persist until the flow is stopped, although partial control may be attained by an inert gas purge during the spray period. The temperature of the liquid metal can either decrease by sensible heat exchange with flow path structures or increase due to the heat of combustion, depending on surface to volume ratio, liquid metal mass flow rate, and the oxygen concentration.

Massive spills will result in pools whose surface and depth are determined by the configuration of catch pans or cell floor arec.. Control of the "pool" fire phase is usually attempted by large engineered systems which will be described later.

\subsection{FIRE PROTECTION METHODS USED IN PRESENT FACILITIES}

The best fire protection is prevention, not extinguishment. True fire protection must be put into the original system design and include such features as leak detectors, catch pans or sumps, isolation, enclosures, dump tanks, inert gas purge, and acciss for cleanup. Ventilation and smoke control are also design features important to fire protection. Differences in size, function, building structure, and climate among the var.ous liquid metal facilities have resulted in a variety of fire protection systems being used. The one consistant method used by all reactor operators is to provide inert atmosphere cell.s for primary 1 iquid metal areas, with oxygen concentration specified at $<5 \%$ on a volume basis. Protection against fires in secondary 1 iquid metal coolant reactor areas and non-reactor test loops varies considerably. Three basic fire fighting methods are used: spreading dry powder on the burning surface, deluge with inert gas, and self-extinguishment.

\section{6 .1 Solid Powders}

For some years, the most common powder extinguishant used has been $\mathrm{NaCl}(\mathrm{Met}-\mathrm{L}-\mathrm{X})$. It is made up of 85 to 90 \% sodium chloride with the remainder polyacetate, magnesi um stearate and attapulgas clay. The latter materials are added to promote flowability and prevent packing. A typical screen analysis gives 908 of the material retained on a U.S. Standard Sieve size 140 mesh. This is equivalent to $90 \%$ of the material greater than $100 \mathrm{~mm}$ diameter. 
Since 1974, the U.S. has been moving toward the use of a Japenese developed product called NAX (a sodium carbonate material). It has been tested and certified for sodium fire use. Its major advantage is that it is chloride free, thus not endangering materials of construction.

Recently, a new product from france has come into the sodium community. It is called Graphex CK.23 $(28,29)$ (primarily a graphitic sulfate). It comes both in powder and in pellet or bar form.

Generally the comments on characteristics and size as well as the manner of fire fighting will apply to all three of the materials. More specific mention of each will be found in later chapters.

1. Manually from sealed bags, using scoop or shovel.

2. Portable extinguisher containing $301 \mathrm{~b}(13.5 \mathrm{~kg})$ of powder.

3. Wheeled extinguishers with up to $50 \mathrm{ft}(\sim 15 \mathrm{~m})$ of hose and containing either 150 or $350 \mathrm{lb}(70$ or $160 \mathrm{~kg})$ of powder.

4. Stationary units with up to $100 \mathrm{ft}(\sim 30 \mathrm{~m})$ of hose or pipe and containing up to $2000 \mathrm{lb}(-900 \mathrm{~kg})$ of powder.

Many other powder materials have been tested against small sodium fires, but only a few are recommended for plant use. They are noted in the table(30) (see Figure 48).

The only fixed powder distribution system presently in use in the United States is at EBR-II. Some interest is being shown in $a$ mechanical spreader fed from heated storage bins, but this concept has not been developed. The fixed pipe Met-L-X systems installed at EBR-II in Idaho use a 32-nozzle array fed by two $2000-1 \mathrm{~b}(900 \mathrm{~kg})$ Met-L-x units, with $3 \mathrm{lb} / \mathrm{ft}^{2}\left(15 \mathrm{~kg} / \mathrm{m}^{2}\right)$ average coverage of the floor area. This is used as a secondary bacsup system.

Several potential problems with fixed pipe powder systems are recognized: (35)

1. Operator inability or reluctance to test in place due to cleanup problems.

2. Possible corrosive effects of powder on system components.

3. Possible plugging of delivery pipe or nozzles.

4. Operation is 1 imited to one use; if fire is not extinguished or reignites no further control is available. 
5. All existing powder systems use an agent whose density is greater than that of liquid sodium. Rapid or uneven discharge may permit the powder to sink.

6. Possible incomplete coverage of burning surface due to "shadows" by cell structures.

7. Possible non-uniform coverage due to thermal convection currents.

8. Possible non-uniform coverage due to jet action of compressed gas.

9. Possible caking or packing in the storage tank with attendant incomplete discharge.

Because of the potential problems and the lack of proof testing under realistic accident conditions, the use of 1 arge fixed pipe powder systems is seriously questioned for liquid metal fire protection.

\section{6 .2 Inert Gas}

Inert gas is used in two ways as a liquid metal fire protection agent; first, as a passive system where the oxygen conzentration is kept at low levels (1-5 volume percent), and second as an active system where nitrogen or argon is added rafialy as a deluge in event of a fire. The first of these is a fire prevention rather than an extinguishment method. A relatively gas-tight enclosure is provided, equipped with a pressure relief vent if necessary. The atmosphere within it is continuously monitored for oxygen concentration. Nitrogen is usually used to dilute the oxygen. The maximum oxygen consentration specified for the inerted atmosphere depends on the size of the enclosure and maximum postulated sodium spill, but must be less than 58 by volume to be effective as an inert blanket. This is the only concentration that is capable of suppressing spray fires. Its disadvantage is the high initial expense, maintenance problems, and potential health hazard to personne1. Also, the system loses its inerting effect when air is admitted during maintenance procedures.

The inert gas deluge is an active extinguishment system. The inert gas (either nitrogen or argon) is introduced into a semi-enclosed space in which the spilled liquid metal is collected. The inert gas reduces the oxygen content of the atrosphere near the burning surface until combustion can no longer be supported. The chief problem with this system is the potential for thermal convection currents sweeping the inert gas from the interfacial area, thereby allowing oxygen to enter. The geometry must be optimized and a continual supply of inert gas assured until the sodium mass has cooled below its ignition temperature. Examples of facilities using this type of fire suppression are the core Components Test loop at Argonne 
National Laboratory, the Multiple Assembly Cooling Cask Task at Oak Ridge National Laboratory, and the secondary sodium systems of liFTF (see Figures 49 and 50). (31) None of these systems hav $\epsilon$ been used in an actual fire.

Studies by Bulmer(32) of UKAEA on nitrogen used in 1 iquid form were most interesting. He used the heat of vaporization as a means of lowering the heat of the sodium and acting as a querching media. He suggests that the practical limitation was the size of the liquid nitrogen dewar available. He indicated tha: about $20,000 \mathrm{ft}^{3}\left(566 \mathrm{~m}^{3}\right)$ was the size compartment that could be treated realistically. He felt that a practical upper $1 \mathrm{imit}$ in size for this type of protection system might be $3000 \mathrm{~m}^{3}$ or about $100,000 \mathrm{ft}^{3}$.

Hilliard and Muhlestein(33) conducted a series of experiment:s on secondary system containment modeled after the design for FFTF. They found that space isolation with a post fire nitrogen purge was very effective. When the fire was out the residues showed less than $10 \%$ of the sodium burned. This series of tests showed the value of catch pans and pipeways that: 1 imited the surface area as means of mitigating the fire potential.

Thomson of the UKAEA(34) showed that most of the powder extinguishing agents tried were ineffective. This has been found generally in tests elsewhere. He noted that vermiculite was effective in both stopping the fire and in reducing the fume. It was concluded however that vermiculite only insulates the surface and that the fire continues to smolder and burn. It will tend to continue until all the liquid metal is oxidized because of the coarseness of the cover which allows air to slo'nly diffuse to the surface of the melt. Vermiculite also has value as an insulator in some applications with respect to conzrete and steel 1 iner plates.

\subsubsection{Other Extinguishment Methods}

Reasonably gas-tight enclosures normally filled with air are used to protect some 1 iquid metal systems. This "confinement" structure need not be as complex or expensive as the gas-tight inerted "containment" structures. Liquid metal spilis are confined to a local metal lined area at the bottom of the enclosure, and release of smoke beyond the confinement barrier is greatly reduced. The liquid metal can ignite in the normal air atmosphere, but the combustion may exhaust the available oxygen to levels at which "burning" is slowed and the liquid metal pools cool down. The effectiveness of this fire protection system was demonstrated. by an actual 8 gallon ( 30 liter) spill of $1550^{\circ} \mathrm{F}\left(843^{\circ} \mathrm{C}\right.$ ) sodium at ANL in 1955.(35) Since a fire can be expected within the structure, care must be taken to assure the structural integrity will be maintained uncer accident conditions. All equipment enclosed by the structure will be exposed to heat, smoke, and pressure pulse. 


\section{$6.7 .1 \quad$ Background}

The major United States effort to evaluate the effects of sodium fires began in 1950. These early evaluations were carlied out at Knolls Atomic Power Laboratories, (36) at MSA Restarch (MSAR) Corporation to support Naval Reactor problem areis $(37)$ and at Atomic power Development Associates and

Detroit Edison Company in support of the FERMI reactor. All test:s concentrated on sodium sprayed into a partially or fully inelted chamber. They dealt mainly with evaluating pressure pulses which could cause system damage. The evaluation which con:iidered the extinguishment problem most directly was the MSAR study. (38) This study examined several means of extinguishment and reduction of the containment pressure pulses of spray fires. These included inert gas, sodium chloride powder application, externally cooled walls, and smothering with a mineral wool insulation. The most effective method and the one given final tests was to reduce the oxygen content of the chamber to less than 58 by volume and to cool the chamber walls by external coolants.

By the mid-1950 decade, several sodium cooled reactors were in the design and construction phase. In addition, larce engineering support loops were being built to test major components. Major sodium fire evaluation testing and analysis was performed for the safety analyses of the Experimental Bresder Reactors (EBR-I and -II), Sodium Reactor Experiments, (SRE) and Hallam (HNPF) reactors. Virtually none of these specifically evaluated extinguishment methods. Rather, the stulies concentrated on:

1. The effects of violent sprays of sodium into chambers with atmospheres ranging from normal air to totally inerted. The major parameter of interest was maximum pressure generated within the containment system. Such evaluations were carried out at Atomics International (39). and Argonne National Laboratory (ANL). (40)

2. An extensive evaluation of pool fire characteristics, especially those pertaining to aerosol formation and behavior. The Atomics International evaluations also carefully evaluated the characteristics of sodium fires such as ignition temperatures and burning rates under a wide variety of conditions. These studies provided valuable insights for fire protection such as the data on burning rates in reduced oxygen concentrations. For example, $(41,42)$ at oxygen concentrations below 48 by volume, sodium at $1000^{\circ} \mathrm{F}\left(583^{\circ} \mathrm{C}\right)$ does not undergo rapid burning, but a slow reaction will occur at oxygen rates as low as $0.1 \%$ by volume. 
The development testing of extinguishant methods has been larclely performed on a very small scale by engineers and fire proi:ection personnel at individual sites. Much of the work is undocumented or informally documented in brief letter reports. Typical tests involve a few pounds of sodium burned in outdoor burn pans with extinguishant applied manually, or with small portable extinguishers. The other major test area has been actial experiments in fighting fires which is summarized in a survey document by Argonne National Laboratory. (43)

The Ansul Company(44) evaluated the effectiveness of Met--L-X (NaCl) on various sizes of sodium and other 1 iquid metal fires. The largest sodium fire was $2.2 \mathrm{ft}^{2}\left(0.2 \mathrm{~m}^{2}\right)$ with 36 los $(16 \mathrm{~kg})$ of sodium heated slowly to $896^{\circ} \mathrm{F}\left(480^{\circ} \mathrm{C}\right)$. After a 48-second pre-burn, $301 \mathrm{~b}(13.5 \mathrm{~kg})$ of Met-L-X extinguished the fire completely in slightly over a minute.

Mine Safety Appliance Research (MSAR) evaluated a wide variety of extinguishants, including organic materials, on small (5 kg) fires. (37) Most organic materials were not effective at all or, if initially effective, the fire burned through later. A unique material, polyurethane foam, appeared promising in these small fires. No widespread use of this material has been made up to this time.

Similar tests were performed by Atomics International (AI) who performed scouting tests with fifty different agents on 5 lb $(2.3 \mathrm{~kg})$ sodium fires in $1.6 \mathrm{ft}^{2}\left(0.15 \mathrm{~m}^{2}\right)$ burn pans. (39) Many compounds were at least partially effective on the small fires, with the best being Met-L-X, sodium carbonate, sodium stearate, polystyrene, biphenyl-sodium bicarbonate mixture, magnesium oxide, large-grain vermiculite, G-1 powder, 1 ampblack, sand, and calcium carbonate. Each of these materials exhibited some deficiency, however, and the weight of powder extinguishant applied generally exceeded the weight of sodium by factors of 3 to 6 .

Argonne National Laboratory (ANL) performed powder flow tests at the EBR-II site using an Ansul 2000-1b $(900 \mathrm{~kg})$ Met-L-X unit with a fixed pipe, 16 nozzle array. (35) About $65 \mathrm{ft}(20 \mathrm{~m})$ of 2 -inch schedule 40 pipe was used with graduations down to $1 / 2$ inch $(13 \mathrm{~mm})$ pipe at each nozzle. Standard screwed pipe fittings were used, and the nozzle distance from floor varied from $(1.4$ to $3.0 \mathrm{~m})$. Sixteen Ansul " $\mathrm{Z}$ " nozzles were used at $8 \mathrm{fit}(2.5 \mathrm{~m})$ spacing. The purpose of the two tests was to determine the uniformity of powder application. In the first test bags were tied over each nozzle to catch the Met-L-X. Pressure transducers showed that pressure drop was about equal to the four quadrants of the array. The amount of powder caught by the bags varied from $90-128$ lb. ( 41 to $58 \mathrm{~kg}$ ), which was considered satisfactory. Only $121 \mathrm{lb}$. $(55 \mathrm{~kg})$ of Met-L-X powder remained in the tank at the end of the test. The piping was 
dismantled and found to be free of powder. For the second test the bags were removed from the nozzles and the powder was recycled to the Ansul unit. A sheet of polyethylene was spread on the floor below the nozzle. All the powder was delivered within three minutes, but the nitrogen fluidizing gas continued to flow for an additional two mintues. The floor coverage varied from .2 to $.8 \mathrm{in.}$ ( $5 \mathrm{~mm}$ to about $20 \mathrm{~mm}$ ).

\section{7 .3 Current Testing 1971 to 1978}

Huber, Menzenhauer and Peppler,(45) of Germany, did exc $\in l$ lent work in testing extinguishing agents. They likewise fourd linited use for the powders because of their inefficiency and lack of flexibility for application. They developed very sophisticated draining/isolation systems. This will be noted late: r.

Japanese workers(46) have verified many of the same things in their work. They have had excellent success with a product called Netlex (sodium carbonate). This material has been licensed by U.S. firms under the name of NAX for marketing in the West (see Figures 51, 52, and 53).

Fruchard et al, (47) in France have done the most innovative work in developing new agents to apply to sodium fires. They have made a very detailed study of the mechanism of the sodium fire. They have successfully developed an agent that would have fluidity, low density, and the ability to maintain a covering over the sodium to keep the evaporation of the molten sodium from taking place. The agent is spread over a sodium fire as a powder and it expands in what has been reported Menzenauer et $a 1,(28)$ as a volume expansion of $1: 25$. Since it is 1 ighter than the sodium, it has little tendency to sink and with the large volume expansion tends to completely blanket the fire area. It does not appear to form an impermeable crust, so thet removal of the material after the fire has cooled is possible with a vacuum cleaner. Since it is also chloride free as well as expandable, it requires markedly less material to extinguish a fire in comparison to other agents commonly used. A :eport on testing of the material has been completed by the Germans (28).

Liquid Metals Engineering Center (LMEC*) fire protection pe:sonnel have tested sodium carbonate $\left(\mathrm{Na}_{2} \mathrm{CO}_{3}\right.$ ) ( $\mathrm{NAX}$ ) as a substitute for Met-L-X in $30-1 b$ (13 kg) gas pressurized portable ex inguishers. They have found that "30-grit" (approximately 60 mm diameter) NAX will flow from the extinguishers and will suppress $6-\mathrm{ft}^{2}\left(.6 \mathrm{~m}^{2}\right)$ sodium fires more effectively than Met-L-X. U.ij. Department of Energy sponsored testing showed satisfactory

\footnotetext{
* LMEC is now known as Energy Technology Engineering center ( $\mathrm{ETEC})$.
} 
storage and flowability and the preliminary results have resulted in $\mathrm{Na}_{2} \mathrm{CO}_{3}$ (BASE, NAX) being listed by U.L. as an accepted sodiun fire fighting agent that is near chloride free. From the practical point of view, filling of cylinders has shown that NAX has a toxicity problem of its own resulting from handing.

A 1 iquid metal fire protection system development program is underway at HEDL. It is directed toward large scale prcof tests of present and proposed methods of extinguishing large liquid metal fires at major LMFBR facilities. It corsists of a fixed testing facility with manual inert gas deluge of initially air-filled enclosures, and the use of self-extinguishing sumps.

Extensive development work and testing have been carried out at oak Ridge National Laboratory on the use of carbon microspheres for liquid metal fire fighting. The spheres have a size of about 0.02 in. diameter $(0.40 \mathrm{~mm})$. They are made Ercm carbon materials derived from byproducts of asphalt manufacture. Oak Ridge people have reported excellent success with bulk application of this material on both sodium and Iithium fires. At ORNL's suggestion, Hanford Engineering Development Laboratory also used this material successfully on lithium fires. Details of application and source can be obtained by contacting ORNL personnel at the $\mathrm{Y}-12$ plant.

\section{$6.8 \quad$ INSULATION}

Since liquid metal systems are high temperature devices, the: need for insulation is apparent. In the matter of appl:cation, the insulation needs to have at least limited compatibility with the liquid metal coolants. This means that it should not entirely disintegrate when the liquid metals are put on it, and it should not propogate the fire.

A large amount of work with sodium has been done. In most of the testing, the conventional industrial insulation materials hare been used. Most tests have consisted of pouring hot soclium (about $1000^{\circ} \mathrm{F}\left(538^{\circ} \mathrm{C}\right)$ ) on the specimens and evaluating the remains. The extremes of these tests have been total reaction and burning to no reaction and no wetting. The common insiulation materials have a proportion of water contained in the $: m$ which is released with the application of heat. A table of some that were tested in the Japanese program(46) is included for reference to give an idea of the compositions seen in these mat:erials (see Figure 54). The most sodium resistant were the cecanic fibers. However, since sodium reacts with silicon dioxide $\left(\mathrm{SiO}_{2}\right)$ the proportion of $\mathrm{SiO}_{2}$ should be kept to a minimum. The silicon dioxide reacts wfth the sodium to form a low melting eutectic compound that destroys the usefulness of the insulation. In general it can be said that once the insulation has had extensive contact with the sodium it must be rejplaced. The same reasoning can, in general, be applied to other liquid metals. 


\section{BASIC PRINCIPLES}

1. ISOLATION - SEPARATE LIQUID METAL PART OF SYSTEM TO SIMPLIFY FIRE FIGHTING.

2. COMPARTMENTATION OF SPACES.

3. WATERLESS FIRE FIGHTING - NEED REMOTE METHODS - LIMITED HAND FIRE FIGHTING.

4. CATCH BASINS NECESSARY - COROLLARY - SODIUM CONCRETE REACTION. HENCE NEED A COVER / PROTECT CONCRETE.

5. LEAK DETECTION REQUIRED.

6. SYSTEM REDUNDANCY-INSTRUMENTS AND TRACE HEATING AND INERT GAS/FLOOD SYSTEMS.

7. FUME - VENTILATION CONTROL / DISPOSAL. 


\section{REACTOR SAFETY DESIGN CRITERIA}

- CONSERVATIVE DESIGN MARGINS

- INHERENT SAFETY FEATURES

- MULTIPLE BARRIERS TO FISSION PRODUCTS

- PROTECTIVE SYSTEMS TO PREVENT ACCIDENTS

- ENGINEERED SAFETY FEATURES 


\section{HEAT TRANSFER CONFIGURATION} SAFTY FEATURES

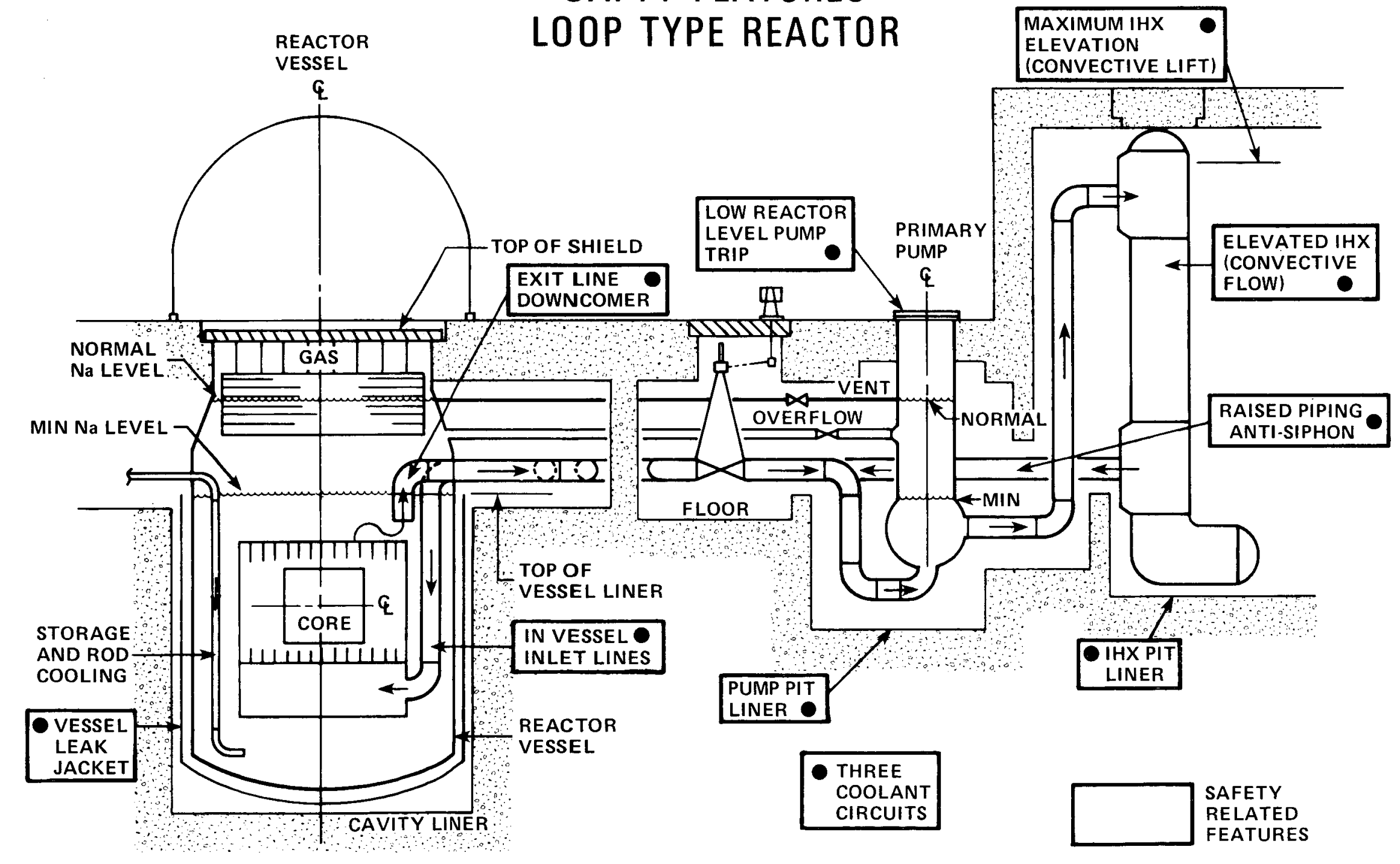

REFERENCE 1

FIGURE 31 


\section{TYPICAL PRIMARY COMPONENT MAINTENANCE}
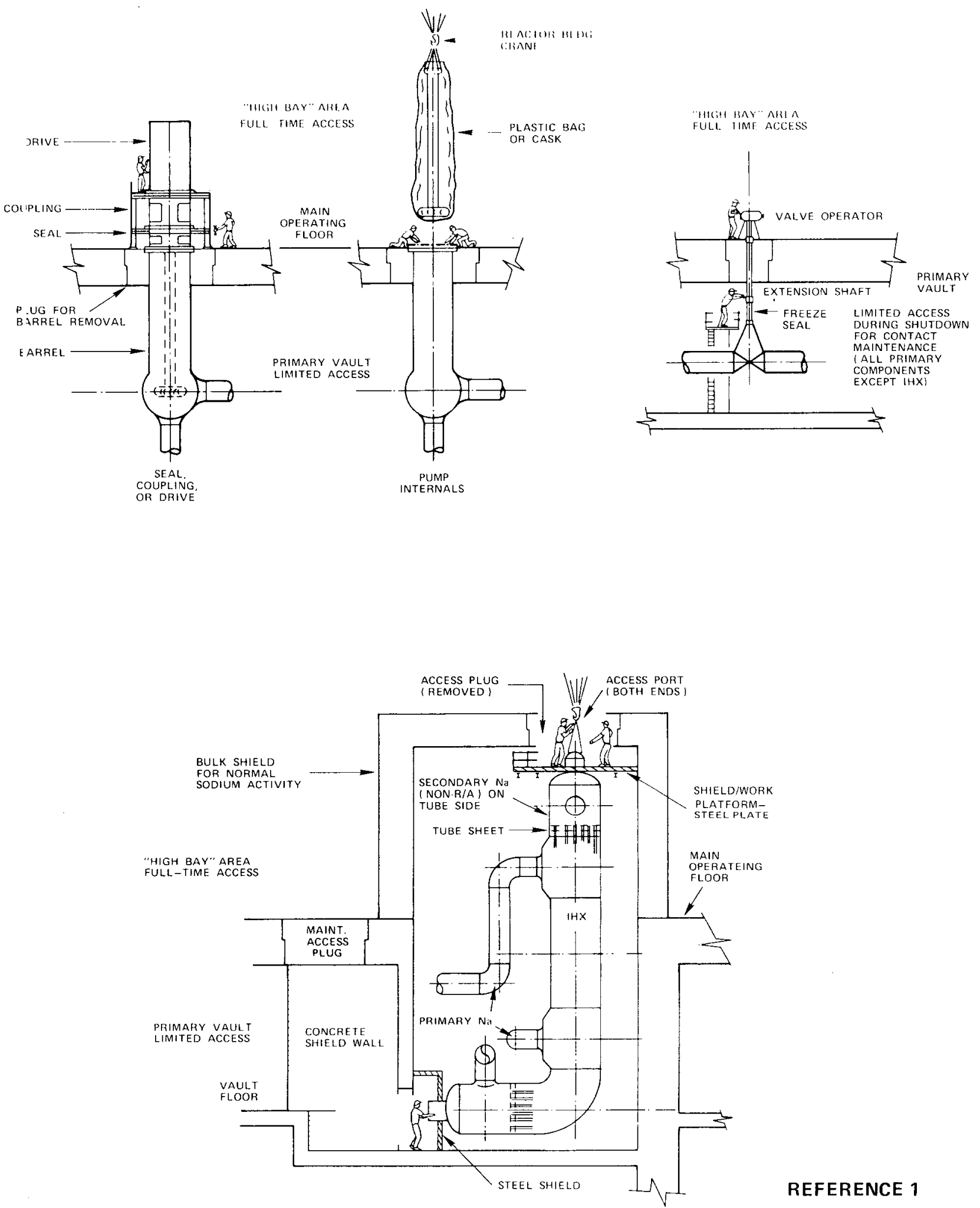

REFERENCE 1

FIGURE 32 


\title{
LMFBR SODIUM FIRE PROTECTION DATA
}

\author{
REQUIREMENTS FOR CONTAINMENT \\ SYSTEM AND REACTOR SUPPORT BUILDING
}

- HOUSE EQUIPMENT NORMALLY CONTAINING PRIMARY SODIUM IN CLOSED, INERTED AND STEEL LINED CELLS.

SLOPE FLOORS OF CELLS AND PIPEWAYS HOUSING SODIUM FILLED EQUIPMENT TO INDUCE COLLECTION OF LEAKED SODIUM TO LOCALIZE DAMAGE AND CLEANUP.

- INSTALL CURBS OR SIMILAR CONFIGURATIONS IN LARGE HORIZONTAL SURFACES TO LOCALIZE SPILLED SODIUM.

- FOR PIPEWAYS OR AREAS CONTAINING SECONDARY SODIUM EQUIP. MENT AT OR BELOW GRADE USE CONCRETE STRUCTURES WITH SLOPING FLOORS TO DIRECT SPILLED SODIUM TOWARD APPROPRIATE CATCH BASINS. SUCH PIPEWAYS ARE TO BE COVERED TO LIMIT GAS TO SUCH SPACES.

- provide ports and plugs to allow VISUAL SURVEY of CELLS AND PIPEWAYS WITHOUT VIOLATING CONTAINMENT OF INERT ATMOSPHERE.

- provide temporary coVERS OVER ACCESS PORTS Of CELLS for USE WHEN CELLS ARE OPENED TO AIR ATMOSPHERE FOR MAINTENANCE OPERATION.

- FOR SAFETY, LAYOUT EQUIPMENT IN CELLS AND ENCLOSED SPACES TO PERMIT ACCESS FOR MAINTENANCE OPERATIONS AND EXIT OF PERSONNEL IN CASE OF EMERGENCY.

- PRotect STRUCTURAL MEMBERS FRoM the EFFEcts of HIGH TEMPERATURES RESULTING FROM Na FIRES BY SUITABLE INSULATING PROVISIONS.

- WITHIN CONTAINMENT ENCLOSE ALL SODIUM OR ALKALI METAL CONTAINING EQUIPMENT IN CLOSED, INERTED AND LINED CELLS OR PIPEWAYS

\footnotetext{
FIGURE $33 \quad$ FFTFDESIGN DESCRIPTION
} 


\section{REQUIREMENTS FOR PLANT FIRE PROTECTION SYSTEM}

- EqUIPMENT BUILDING SPACES CONTAINING PRIMARY Na WITH GAS SAMPLING EQUIPMENT TO DETECT THE PRESENCE OF GRAM QUANTITIES OF SODIUM OUTSIDE OF PRESSURE BOUNDARY.

1) PROVIDE LEAK DETECTION AND LOCATION CAPABILITIES ON OR NEAR SODIUM CONTAINING COMPONENTS AND PIPING. A DESIGN BASIS SODIUM FIRE NEEDS TO BE ESTABLISHED FOR EACH SPACE TO ESTABLISH EXTINGUISHMENT METHODS AND THE TYPE AND QUANTITY OF EXTINGUISHANTS TO BE PROVIDED.

- THE REFERENCE EXTINGUISHANT FOR ALKALI METAL FIRES IS NAX. (SODIUM CARBONATE BASE)

- PROVIDE EQUIPMENT AND PROCEDURES FOR POST FIRE CLEANUPS AND FOR ESTABLISHING THE EXTENT OF DAMAGE (VISUAL INSPECTION ONLY).

- PRoVide PROTECTIVE Clothing AND SElf-CONTAINED BREATHING EQUIPMENT TO PERMIT TRAINED PERSONNEL TO APPROACH THE FIRE SITE.

- fiRE RETARDANT AND/OR EXTINGUISHANTS USED IN SPACES HOUSING ALKALI METALS SHOULD NOT CAUSE HARMFUL OR TOXIC REACTION ON CONTACT WITH ALKALI MATERIALS. 


\section{REQUIREMENTS FOR PIPING \& HEAT TRANSFER SYSTEM}

- DESIGN SODIUM-TO-AIR HEAT EXCHANGERS TO PERMIT CLOSING OF INLET AND OUTLET OR DOORS LIMITING AIR FLOWS IN THE EVENT OF FIRE.

- PROVIDE SHUT-OFF VALVES AT INLET AND OUTLET SODIUM PIPES OR DHX'S* TO ISOLATE EACH UNIT OR MODULE AND LIMIT SODIUM AVAILABLE FOR LEAKAGE.

- DESIGN OF EACH DHX MODULE OR TO LIMIT DAMAGE FROM OR EFFECTS OF SODIUM FIRES TO THE MODULE OR UNIT WHERE THE FIRE OCCURRED.

- DUMP HEAT EXCHANGER HOUSING NEEDS TO BE EQUIPPED WITH ACCESS PORTS FOR DEPLOYMENT OF FIRE EXTINGUISHANT OR FOR INTRODUCING INERT GAS BLANKET IN THE EVENT OF SODIUM FIRE.

- MAINTENANCE PROCEDURES INVOLVING BREACH OF THE SODIUM BOUNDARY SHOULD BE PREPARED IN FULL CONSIDERATION OF SODIUM FIRE POTENTIAL. 


\section{REQUIREMENTS FOR}

\section{HEATING \& VENTILATION SYSTEMS}

- DESIGN VENTILATING CELL EQUIPMENT TO ALLOW ISOLATION OF CONTAINMENT SPACES

THUS LIMIT ANY SPREAD OF PARTICULATES.

- INCLUdES FILTERING AND OTHER DEVICES IN THE DESIGN TO LIMIT DISCHARGE OF AIRBORNE PARTICLES TO LEVELS ACCEPTABLE UNDER AP. PLICABLE POLLUTION CONTROL STANDARDS.

- MAKE PROVISIONS FOR CLEARING OXIDE SMOKE FROM THE ATMOSPHERE IN ENCLOSED SPACES TO ALLOW EFFECTIVE FIRE CONTROL.

- PROVIDE CAPABILITY FOR LOCAL ISOLATION AND ATMOSPHERE CONTROL FOR USE IN CELLS DURING MAINTENANCE OPERATIONS. 


\section{FUNCTIONS OF THE COVER GAS PURIFICATION SYSTEM}

- MAINTAIN THE CHEMICAL PURITY OF THE COVER GAS WITHIN PRESCRIBED LIMITS

- REDUCE the activity of the cover gas TO THE EXTENT THAT:

A) COVER GAS ACTIVITY NEXT TO ELASTOMER SEALS WILL NOT CAUSE PREMATURE FAILURE

B) POTENTIAL LEAKAGE TO THE OCCUPIED AREAS OF THE BUILDING WILL NOT RESULT IN AIRBORNE ACTIVITY IN EXCESS OF MPC

- PROVIDE THE CAPABILITY FOR CONCEN.

TRATION AND DISPOSAL OF $85 \mathrm{Kr}$, SHOULD THE REQUIREMENT BE IMPOSED AT A LATER DATE

- PROVIDE A SOURCE OF RELATIVELY PURE COVER GAS FOR PURGE FOR SODIUM FROST CONTROL OR FOR OTHER USES 


\section{REQUIREMENTS FOR PROCESS MONITORING \& CONTROL SYSTEMS}

- PROVIDE LEAK DETECTION SYSTEM IN SPACES OCCUPIED BY ALKALI METAL CONTAINING EQUIPMENT.

- PROVIDE MEANS OF LEAK DETECTION TO LOCATE LEAKAGE AT MAJOR COMPONENTS AND IN MAJOR PIPING. AS A GOAL THE DETECTION SYSTEM SHOULD SEEK AN OVERALL SENSITIVITY TO DETECT GRAM QUANTITIES OF LEAKED SODIUM IN EITHER AIR OR $\mathbf{N}_{2}$ ATMOSPHERE.

- TO THE EXTENT FEASIBLE LEAK DETECTION EQUIPMENT SHOULD BE INSENSITIVE TO THE ENVIRONMENT, E.G., TEMPERATURE, INERT ATMOSPHERE, RADIOACTIVITY.

LEAK DETECTION SYSTEM SHOULD BE CAPABLE OF IN-PLACE TESTING (FUNCTIONAL CHECK AND CALIBRATION).

- USE SMOKE DETECTORS FOR LEAK/FIRE DETECTION IN THE DUMP HEAT EXCHANGERS.

- THE LEAK DETECTION SYSTEM SHOULD PROVIDE ESSENTIALLY CONTINUOUS SURVEILLANCE AND ALARM CAPABILITY.

- PIPING AND GAS HANDLING EQUIPMENT FOR LEAK DETECTION SYSTEM NEEDS TO BE PROVIDED. 


\title{
MAINTENANCE OF SODIUM SYSTEMS, DESIGN CONSIDERATIONS
}

\author{
- PROVIDE FOR ACCESS AFTER \\ ${ }^{24} \mathrm{Na}$ DECAY \\ - PROVIDE FOR COMPLETE DRAINAGE \\ - DESIGN FOR MAINTENANCE OF \\ MAJOR EQUIPMENT WITHOUT \\ CUTTING THE SODIUM ENVELOPE \\ IF POSSIBLE
}

- PROVIDE ADEQUATE REMOTE LEAK DETECTORS WHERE ACCESS IS RESTRICTED

- PROVIDE FOR RADIOGRAPH WHERE MAINTENANCE IS LIKELY

- PROVIDE CAPABILITY FOR REMOTE MAINTENANCE OF RADIOACTIVE SYSTEMS

- WHERE FUTURE ACCESS IS PROHIBITED, PROVIDE FOR REMOTE MAINTENANCE; PROVIDE SPARE GEAR; OR ELIMINATE MAINTENANCE REQUIREMENTS 


\section{SAFETY CONSIDERATIONS AND FACILITIES SYSTEM FEATURES}

- SHUT OFF ISOLATION VALVES IN SYSTEM

- METAL LINED CATCH BASIN 150\% CAPACITY

- MINIMIZE EXPOSURE TO CONCRETE

- CATCH OR DUMP TANKS IN SYSTEM

- master electrical SWitch

- CUT OFF HEATERS AND PUMPS

- INSTRUCTION FORM ON TESTS OR EQUIP. MENT WHEN UNATTENDED - HOW TO SHUT DOWN

- RAISED FOUNDATIONPLATFORMS

- kEEP WATER aWAy

- PROVIDE $\mathrm{O}_{2}$ DEFICIENCY ALARMS

- LIMIT QUANTITY OF COMBUSTIBLES ESPECIALLY FLAMMABLE AND COMBUSTIBLE LIQUIDS IN AREA

- EXIT REQUIREMENTS OF NFPA 101

- RECOGNIZE HIGH HAZARD IN SODIUM AND RADIOACTIVE AREAS 


\section{KEEPING OXYGEN AND MOISTURE OUT OF SYSTEM}

- MAINTAIN INERT gas COVER OVER SODIUM AT ALL TIMES

- PROVIDE DRIERS FOR COVER GAS MAKE UP IF REQUIRED

- maINTAIN COVER gas PRESSURE ABOVE ATMOSPHERIC

- utilize special seals such as BELLOWS, FREEZE SEALS, OR BACK PRESSURE SEALS WHERE POSSIBLE

- PROVIDE TEMPORARY CLOSURES WHEN SYSTEMS ARE OPEN

- DO NOT PERMIT WATER OR STEAM IN SODIUM CONTAINING AREAS IF NOT ABSOLUTELY NECESSARY

- PROVIDE ADEQUATE VENTS, DRAINS, AND SLOPES

- PROVIDE COLD tRAP to RemOVE TRACES OF OXYGEN, HYDROGEN, ETC. 


\section{LIOUID METAL DESIGN RECOMMENDATIONS}

DESIGN CONSIDERATIONS

\section{REASONS - CONSEQUENCES}

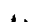

KEEP SODIUM IN

- all-welded construction is required $A T>500^{\circ} \mathrm{F}$

FLANGES AND GASKETS WON'T HOLD SODIUM

LICENSING FOR HIGH TEMPERATURE DESIGN IS REQUIRED GENERALLY. FOR HIGH TEMPERATURE DESIGN.

THIS DECREASES THE CHANCE OF ACCIDENTAL DRAINAGE. TANKS.

- entry to tanks or containment should BE THROUGH THE COVER GAS AT THE TOP

DECREASES THE CHANCE FOR ACCIDENTAL DRAINAGE.

- PROVIDE FOR SYSTEM AND COMPONENT DRAINAGE AND PITCH PIPING FOR NATURAL ADVANTAGE OF GRAVITY.

DUMP TANKS ET AL. ARE NECESSARY FOR CLEAN ING, STORAGE AND MAINTENANCE.

- take advantage (where useful) of ELEVATION DIFFERENCES FOR NATURAL ADVANTAGE OF GRAVITY.

IN LOSS OF POWER SITUATIONS THIS IS A GOOD SAFETY PROCEDURE FOR THE SYSTEM.

\begin{tabular}{l} 
TAKE ADVANTAGE (WHERE USEFUL) OF \\
ELEVATION DIFFERENCES FOR NATURAL \\
CONVECTION COOLING. \\
\hline INSTRUMENTATION SHOULD NOT PENETRATE \\
THE TANKAGE OR PIPING TO SEE THE Na.
\end{tabular}
THE TANKAGE OR PIPING TO SEE THE Na.

IN LOSS OF POWER SITUATIONS THIS IS A GOOD SAFETY PROCEDURE FOR THE SYSTEM.

ALL WELDED THIMBLES OR LIKE DEVICES SHOULD BE PROVIDED TO MAINTAIN SYSTEM SODIUM INTEGRITY AND TO PROVIDE FOR MAINTENANCE AND REPAIR.

SODIUM INCREASES ABOUT $3 \%$ IN VOLUME UPON GOING FROM SOLID TO LIQUID AND ABOUT $12 \%$ MORE FROM MELTING POINT TO $1000 \circ \mathrm{F}$ SODIUM SOLID TO LIOUID AND AS A FUNC TION OF TEMPERATURE.

PREHEAT (SYSTEM HEATING) IS REQUIRED TO KEEP SODIUM MOLTEN. PREHEAT AT $50^{\circ} \mathrm{F} / \mathrm{hr}$ OR LESS. PROGRAM FROM FREE SURFACES THROUGH THE SYSTEM.

- PROVIDE SODIUM PURIFICATION SYSTEM. PROVIDE MEANS OF LEAK DETECTION.

- DESIGN SYSTEM WITH THE NEED TO REPLACE/ MAINTAIN COMPONENT. THIS INCLUDES CLEANING INSIDE AND OUT.

CONSIDER MEANS OF FIRE PREVENTION/ SUPPRESSION.
MELTING POINT Na IS $208^{\circ} \mathrm{F}$. HEATING IS RE. QUIRED TO MELT, RAISE, AND MAINTAIN OPERATING TEMPERATURES.

REQUIRED TO MAINTAIN PURITY TO DECREASE CORROSIVE EFFECT 10 wppm, $0_{2} 15$ wppm C OR LESS

TANKAGE AND LINES ARE INSULATED AND LEAKS ARE NOT NORMALLY VISIBLE. HENCE, A MEANS OF DETECTION EXTERNAL TO THE INSTALLATION IS NECESSARY.

DESIGN HOPEFULLY PROVIDES 20-30 YEAR LIFE BUT USAGE NEARLY ALWAYS CALLS FOR REMOVAL/ REPAIR. ANTICIPATE THIS IN LAYOUT AND ARRANGEMENT WITH ADEQUATE CLEARANCES FOR SHIELDING AND WORK SPACE

PROVIDE EXTINGUISHERS - CATCH BASINS - GAS BLANKETS, ET AL. FOR FIRE CONTROL.

\section{FIGURE 42}




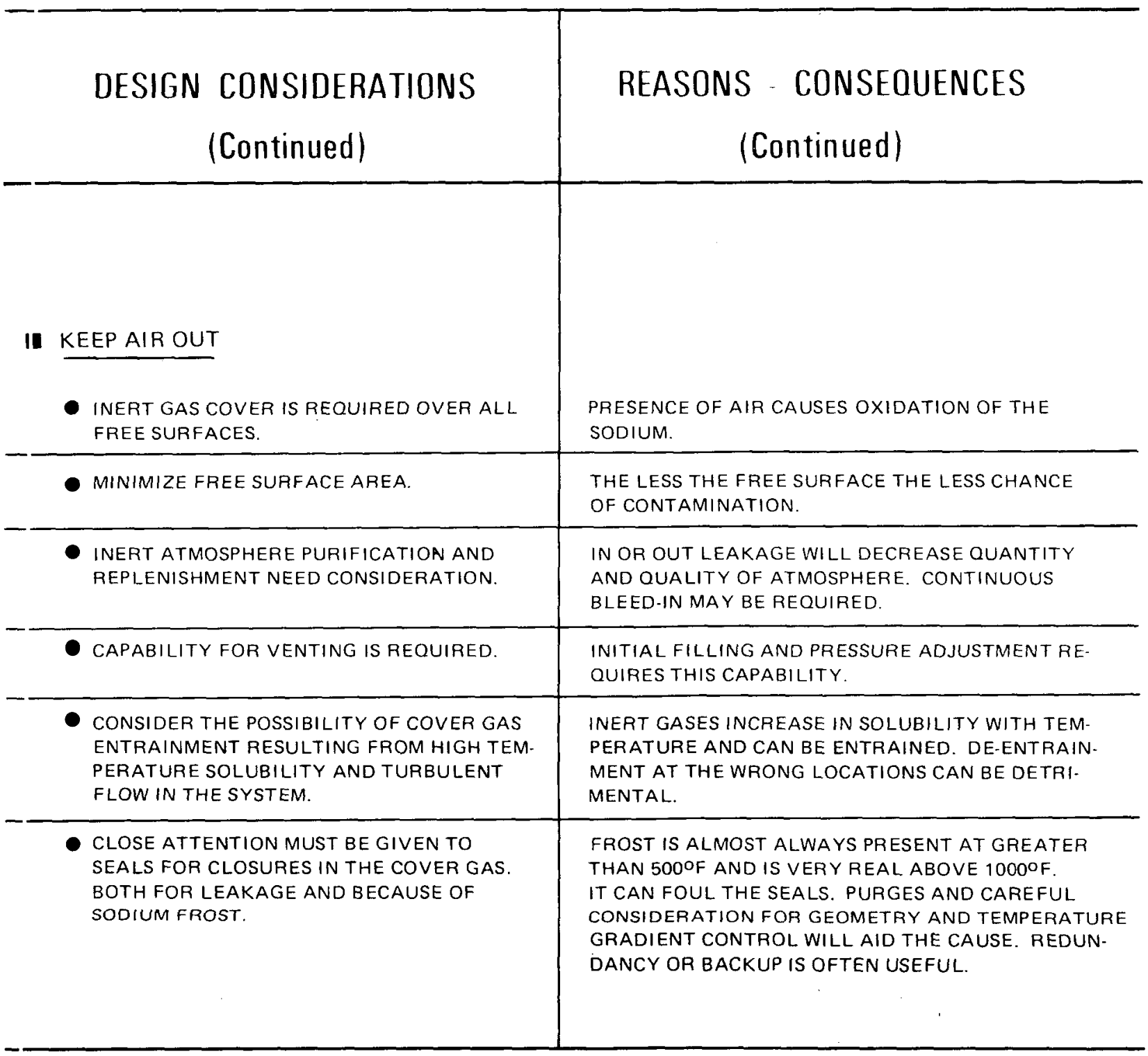

FIGURE 43 


\section{SODIUM COOLED REACTOR COST DISTRIBUTION TO PROCESS SYSTEMS}

\begin{tabular}{|c|c|c|c|}
\hline DIRECT COST ITEM: & $\begin{array}{l}\text { NUCLEAR } \\
\text { ISLAND } \\
(\%)\end{array}$ & $\begin{array}{l}\text { BALANCE } \\
\text { OF PLANT } \\
(\%)\end{array}$ & $\begin{array}{l}\text { TOTAL } \\
\text { PLANT } \\
(\%)\end{array}$ \\
\hline REACTOR COMPLEX & 9.3 & 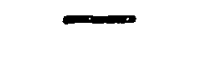 & 5.7 \\
\hline HEAT TRANSFER SYSTEM & 40.2 & 6.7 & 27.7 \\
\hline $\begin{array}{l}\text { TURBINE/GENERATOR } \\
\text { COMPLEX }\end{array}$ & - & 54.4 & 19.4 \\
\hline INSTRUMENTATION SYSTEM & 8.8 & 1.5 & 6.0 \\
\hline AUXILIARY SYSTEMS & 7.6 & 7.8 & 8.5 \\
\hline ELECTRICAL SYSTEMS & 2.5 & 12.6 & 6.6 \\
\hline SUPPORT EQUIPMENT & 7.5 & 2.0 & 5.3 \\
\hline SITE ANDSTRUCTURES & 24.1 & 15.0 & 20.8 \\
\hline TOTAL & 100 & 100 & 100 \\
\hline \multicolumn{4}{|l|}{ SUMMARY } \\
\hline $\begin{array}{l}\text { SODIUM HEAT TRANSFER } \\
\text { SYSTEM }\end{array}$ & & & 24.0 \\
\hline $\begin{array}{l}\text { AUXILIARY SYSTEMS, } \\
\text { NUCLEAR PLANT }\end{array}$ & & & 4.7 \\
\hline $\begin{array}{l}\text { OTHER AUXILIARY } \\
\text { SYSTEMS (PREHEAT IN } \\
\text { THE NON-NUCLEAR PLANT) }\end{array}$ & & & 0.3 \\
\hline $\begin{array}{l}\text { PERCENT OF TOTAL PLANT } \\
\text { ATTRIBUTED TO SODIUM } \\
\text { AND AUXILIARY SYSTEMS }\end{array}$ & & & 29.0 \\
\hline
\end{tabular}


POOL (POT) vs LOOP COMPARISON

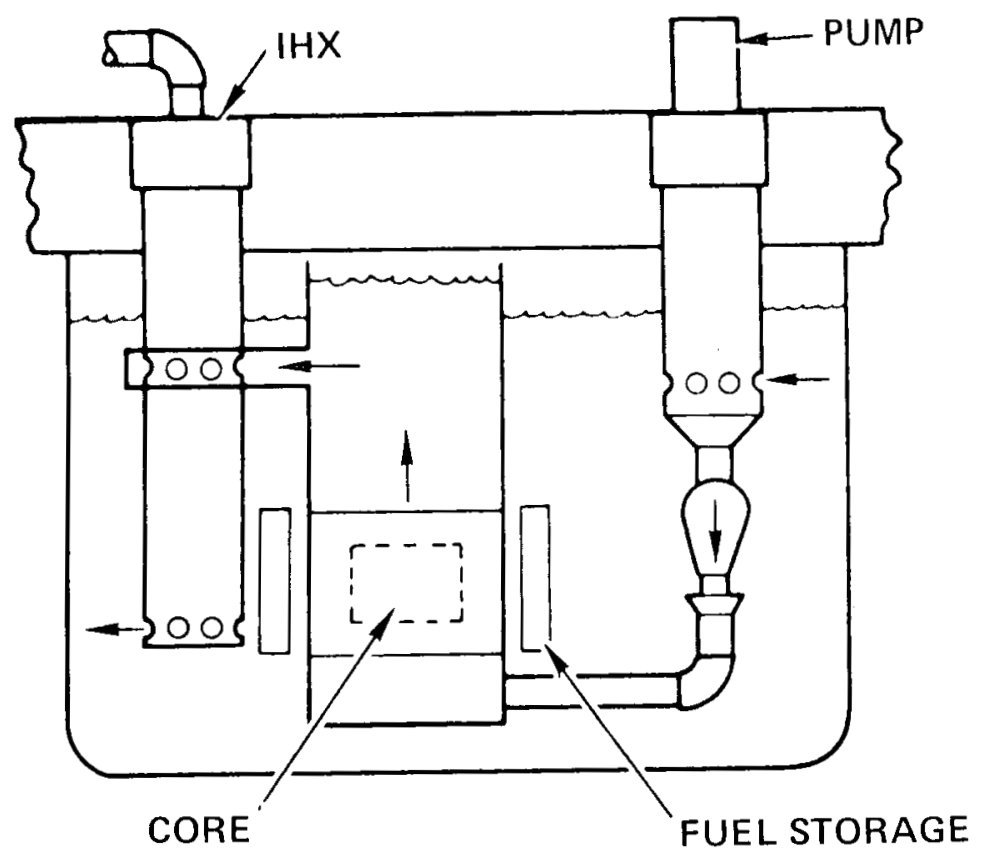

POT

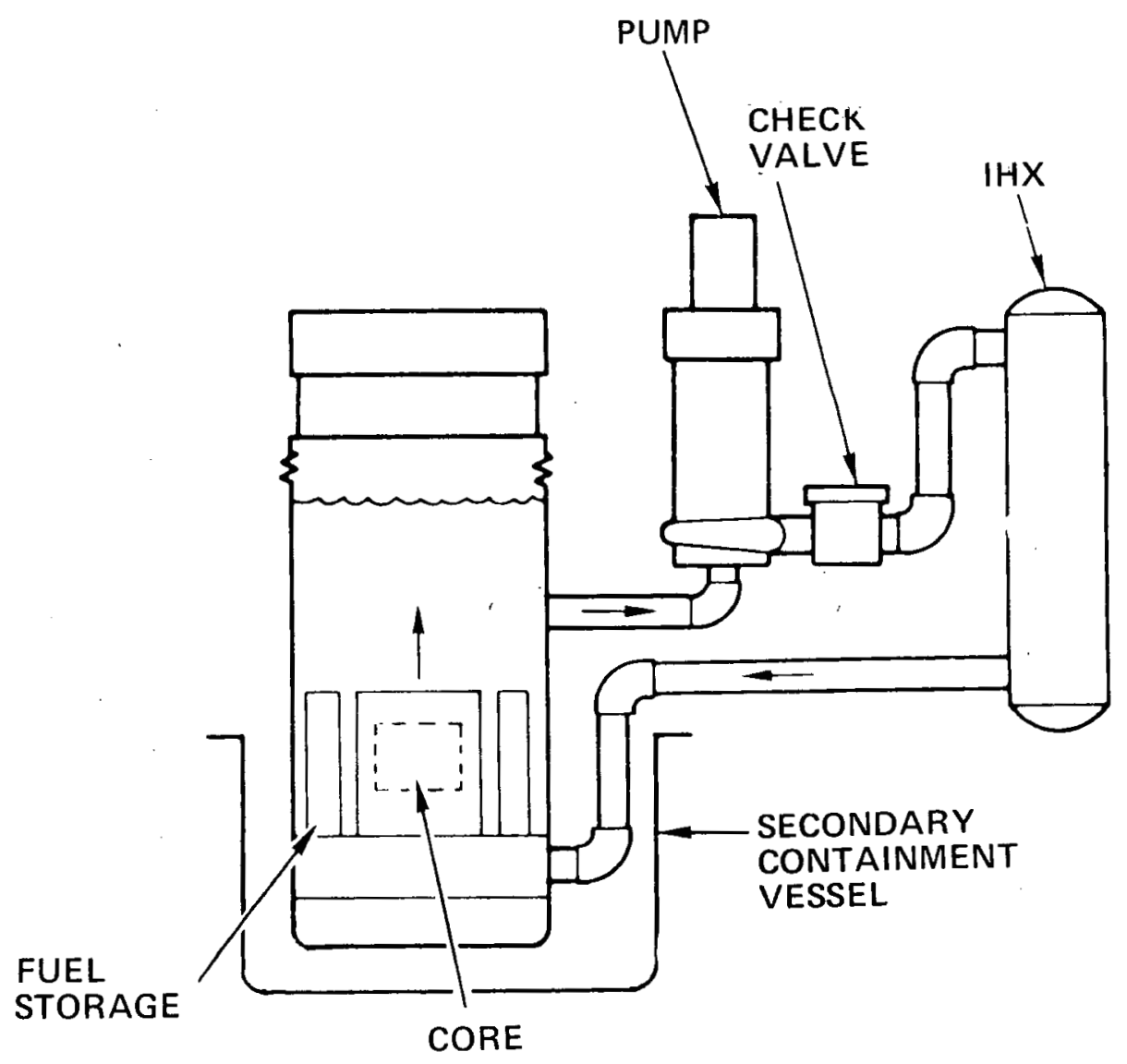

REFERENCE 1

LOOP 


\title{
RADIOACTIVE EFFLUENTS FROM FAST BREEDER REACTORS
}

\author{
PLANNED RELEASES
}

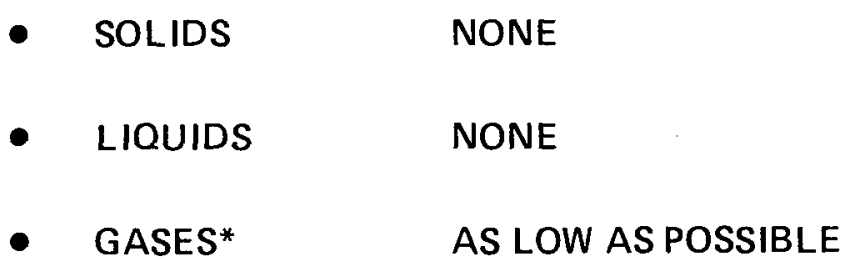

DESIGN GOAL IN A DEMONSTRATION PLANT:

LIMIT THE LEAKAGE OF GASEOUS ACTIVITY TO AN ANNUAL AVERAGE EXPOSURE LEVEL AT THE SITE BOUNDARY THAT IS NO GREATER THAN $1 \%$ OF THE EXPOSURE FROM NATURAL BACKGROUND.

*NOTE:

RADIOACTIVITY RELEASE GUIDELINES ARE FOUND IN DOE ORDER 5480 (FORMERLY DOE MANUAL CHAPTER 0524)

ALSO, CURRENT N.R.C. REGULATIONS SHOULD BE CONSULTED. 


\section{PROGRESSION OF SODIUM THROUGH THE INSULATION AFTER INTERNAL LEAK}

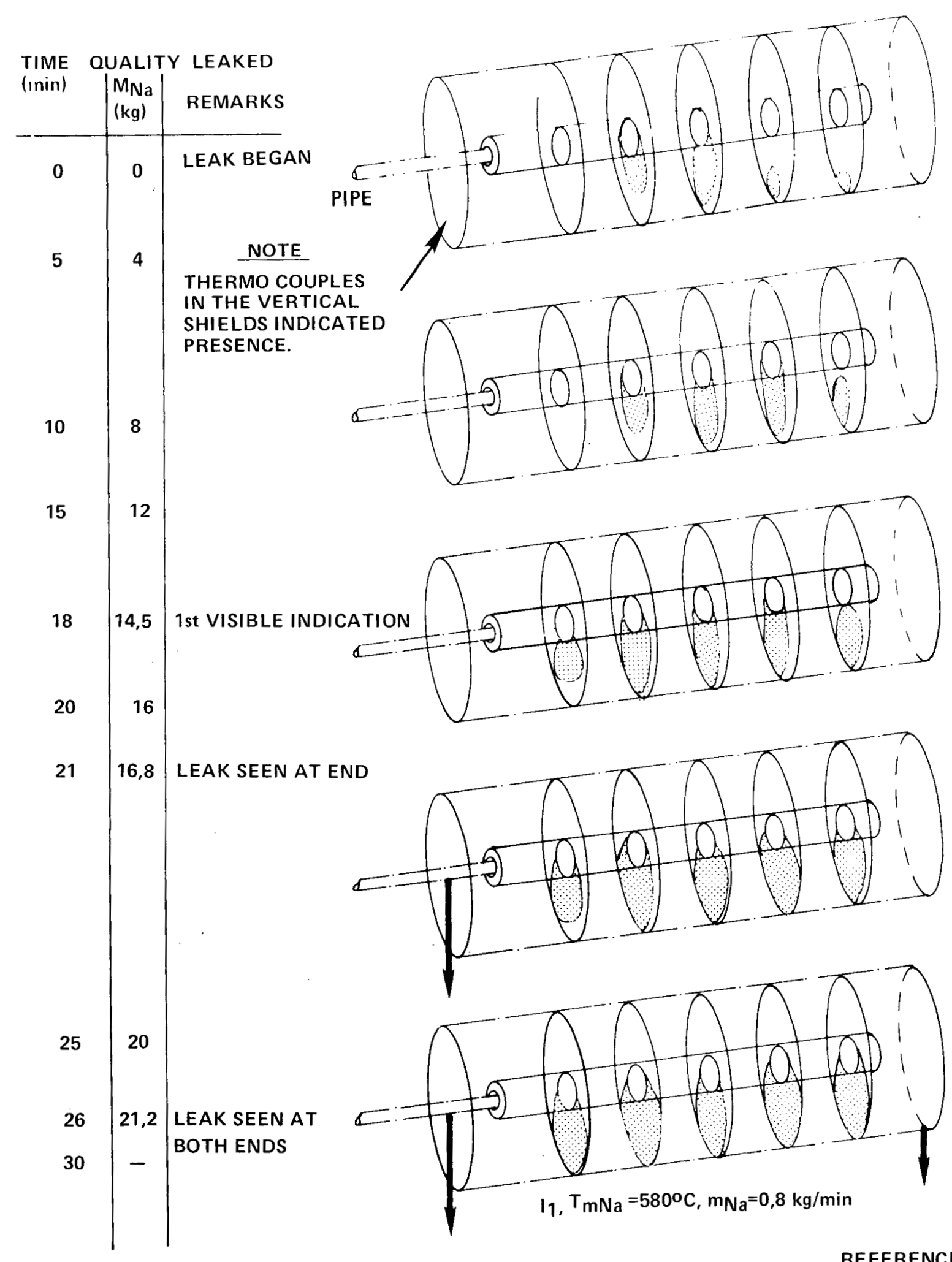

FIGURE 47 


\section{POSSIBLE FIRE-EXTINGUISHING MATERIALS}

\begin{tabular}{|c|c|c|c|c|c|c|c|}
\hline \multirow[b]{2}{*}{ EXTINGUISHANT } & \multirow[b]{2}{*}{ COMPOSITION } & \multicolumn{6}{|c|}{ BEST FOR } \\
\hline & & $\mathrm{Li}$ & $\mathrm{Na}$ & K & $\mathrm{Rb}$ & $\mathrm{Cs}$ & NaK \\
\hline GRAPHITE & CARBON & $x$ & $x$ & & & & \\
\hline MET-L-Xb & RESIN-COVERED NaCl & & $x$ & $x$ & $x$ & $x$ & $x$ \\
\hline PYRENE G-1 & RESIN-COVERED NaCl & & $x$ & $x$ & $x$ & $x$ & $x$ \\
\hline SODA ASH $(\mathrm{NaX})$ & RESION TREATED $\mathrm{Na}_{2} \mathrm{CO}_{3}$ & & $x$ & $x$ & $x$ & $x$ & $\mathrm{x}$ \\
\hline $\mathrm{CaCO}_{3}$ & $\mathrm{CaCO}_{3}$ & & $x$ & $x$ & $x$ & $x$ & $x$ \\
\hline TEC POWDER ${ }^{b}$ & $\begin{array}{l}\text { TERNARY EUTECTIC } \\
\text { CHLORIDE MIXTURE }\end{array}$ & & $x$ & $x$ & $\mathrm{x}$ & $x$ & $x$ \\
\hline $\operatorname{Nax}$ & $\mathrm{NaCO}_{3}$ AND ADDITION & & $\mathrm{x}$ & & & & \\
\hline LITH-X & GRAPHITE BASE & $x$ & $x$ & & & & \\
\hline POLYURETHANE FOAMC & - & & $x$ & $x$ & $x$ & $x$ & $x$ \\
\hline PURPLE K & FREE-FLOWING $\mathrm{KHCO}_{3}$ & \multicolumn{6}{|c|}{ DO NOT USE } \\
\hline SAND & DRY $\mathrm{SiO}_{2}$ & & $x$ & $\mathrm{x}$ & & & \\
\hline ABC POWDER & - & & & DON & T USE & & \\
\hline DRY POWDER & FREE-FLOWING $\mathrm{NaHCO}_{3}$ & & & DO $N$ & T USE & & \\
\hline CARBON DIOXIDE & $\begin{array}{l}\mathrm{CO}_{2} \text {-RE-IGNITES, } \\
\text { MAY PRODUCE CO }\end{array}$ & & & DON & T USE & & \\
\hline CARBON TETRACHLORIDE & $\mathrm{CCl}_{4}-\mathrm{VIOLENT}$ REACTION & & & DO $N$ & T USE & & \\
\hline WATER & $\mathrm{H}_{2} \mathrm{O}$-VIOLENT REACTION & & & DON & T USE & & \\
\hline WATER-BASED FOAMS & $\mathrm{H}_{2} \mathrm{O}-\mathrm{VIOLENT}$ REACTION & & & DO $N$ & T USE & & \\
\hline CARBON MICROSPHERES & ASPHALTIC CARBON & $x$ & $x$ & & & & \\
\hline
\end{tabular}

a USED FOR Na, K, Rb, Cs, NaK IN SMALL LEAKS

b EXTINGUISHANT/METAL WEIGHT RATIO IS $1 / 2$ TO 1/3 FOR TEC AND Met-L-X

C MUST BE APPLIED BEFORE TEMPERATURE REACHES $800^{\circ} \mathrm{F}$

REFERENCE 2

FIGURE 48 


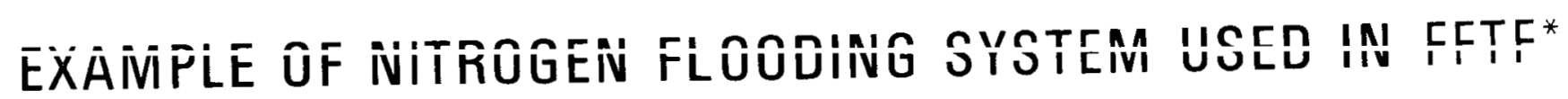

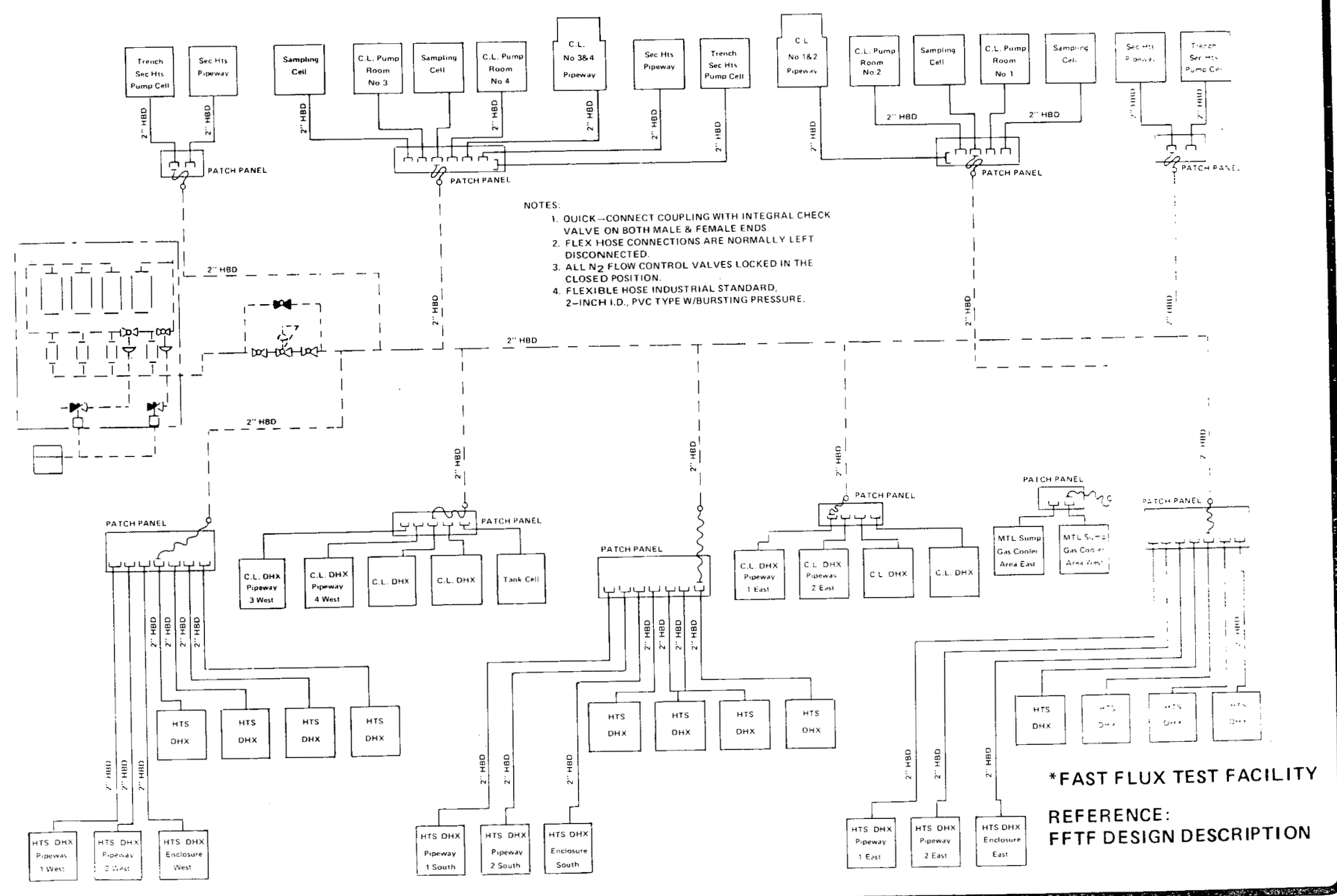




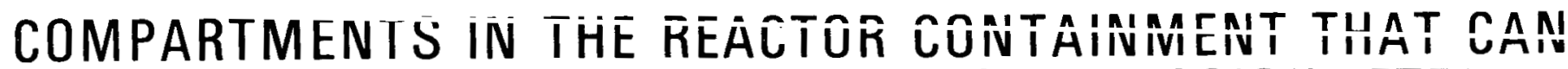
BE FLOODED WITH $\mathrm{N}_{2}$ GAS FOR FIRE SUPPRESSION FFTF*

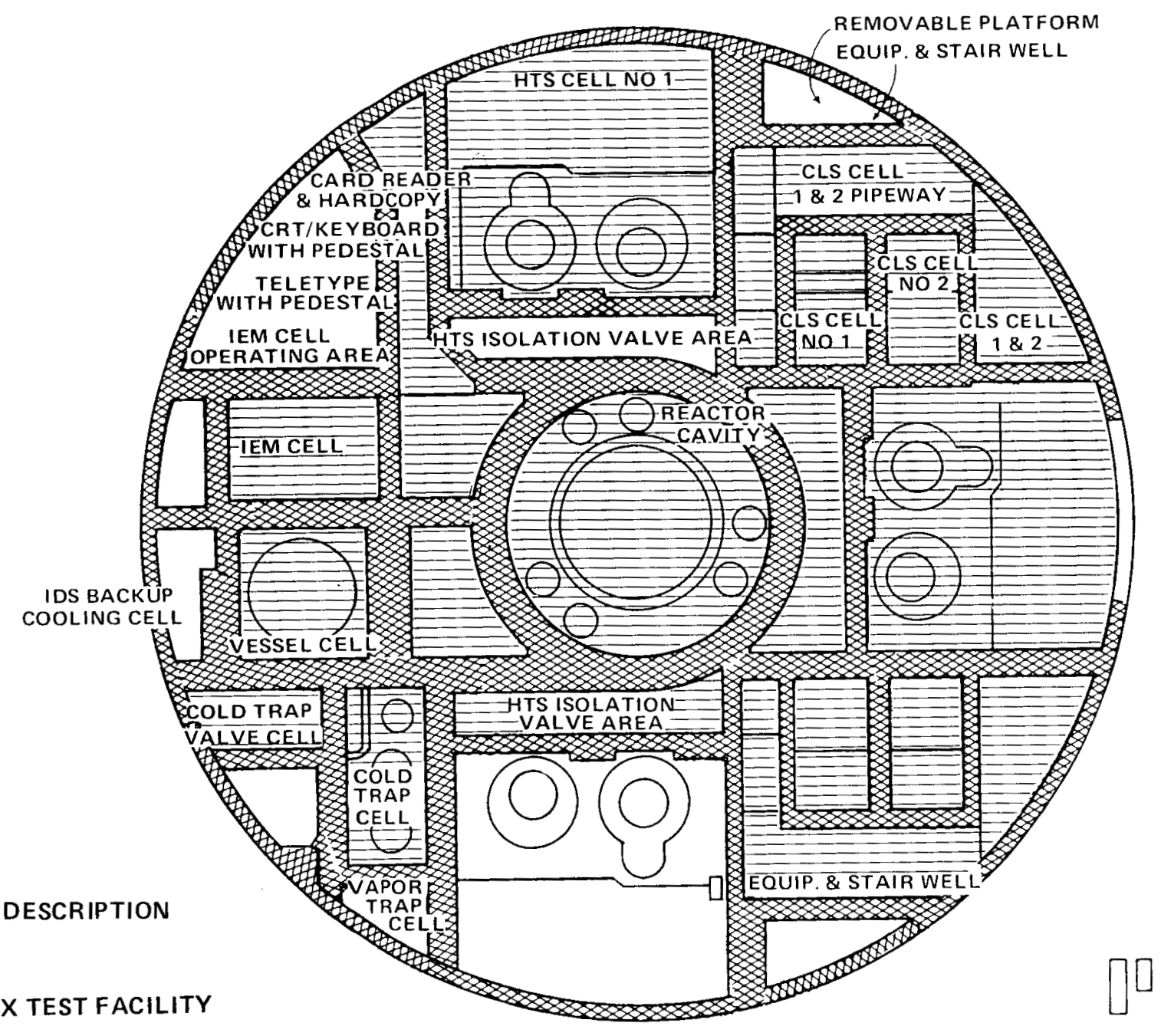

REFERENCE:

FFTF DESIGN DESCRIPTION

*FAST FLUX TEST FACILITY

LINED AREAS CAN BE FLOODED WITH NITROGEN

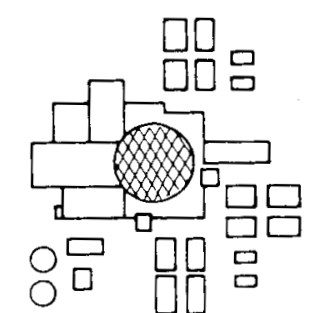

KEY PLAN 



\section{CONDITIONS FOR FIRE-EXTINGUISHING EXPERIMENT}

\begin{tabular}{|c|c|c|c|}
\hline & No. 1 & No. 2 & No. 3 \\
\hline 1. $\mathrm{Na}$ & $10 \mathrm{~kg}$ & $20 \mathrm{~kg}$ & $30 \mathrm{~kg}$ \\
\hline 2. COMBUSTION & $50 \times 50 \times 10 \mathrm{H}_{\mathrm{cm}}$ & $100 \times 60 \times 10 \mathrm{H}_{\mathrm{cm}}$ & $100 \times 100 \times 10 \mathrm{H}_{\mathrm{cm}}$ \\
\hline $\begin{array}{l}\text { 3. LIOUID-Na } \\
\text { DEPTH }\end{array}$ & $4.0 \mathrm{~cm}$ & $3.3 \mathrm{~cm}$ & $3.0 \mathrm{~cm}$ \\
\hline 4. IGNITION FUEL. & $\begin{array}{ll}\text { KEROSENE } & 6 \ell \\
\text { GASOLINE } & 6 \ell\end{array}$ & $\begin{array}{ll}9 & \ell \\
9 & \ell\end{array}$ & $\begin{array}{ll}9 & \ell \\
9 & \ell\end{array}$ \\
\hline $\begin{array}{l}\text { 5. FIRE } \\
\text { EXTINGUISHER }\end{array}$ & TYPE 20 & TYPE 50 & TYPE 300 \\
\hline $\begin{array}{l}\text { 6. EXTINGUISHING- } \\
\text { AGENT AMOUNT }\end{array}$ & $\begin{array}{ll}A B C & 6 \mathrm{~kg} \\
\mathrm{BC} & 8 \mathrm{~kg}\end{array}$ & & \\
\hline & $\begin{array}{l}\mathrm{NaCl} \\
\mathrm{NATLEX} \quad 5 \mathrm{~kg} \\
(\mathrm{NaX}) \\
(2.6 \mathrm{~cm} \\
\quad \text { THICKNESS })\end{array}$ & $\begin{array}{l}\text { NATLEX } 15 \mathrm{~kg} \\
(\mathrm{NaX}) \\
(3.3 \mathrm{~cm} \\
\text { THICKNESS })\end{array}$ & $\begin{array}{l}\text { NATLEX } 60 \mathrm{~kg} \\
(\mathrm{NaX})\end{array}$ \\
\hline $\begin{array}{l}\text { 7. PRESSURE } \\
\text { SOURCE }\end{array}$ & $\mathrm{CO}_{2} \quad 155 \mathrm{~g}$ & $\begin{array}{l}\mathrm{CO}_{2} \quad 450 \mathrm{~g} \\
(150 \mathrm{~atm})\end{array}$ & $\begin{array}{lr}\mathrm{N}_{2} & 40 \\
& (150 \mathrm{~atm})\end{array}$ \\
\hline 8. APPLYING TIME & 20 SEC: & 60 SEC. & 2 MIN: 30 SEC. \\
\hline
\end{tabular}




\section{INSULATION MATERIALS AND THEIR COMPOSITION}

\begin{tabular}{|c|c|c|c|c|c|c|c|c|c|c|}
\hline \multirow[b]{2}{*}{ LAG. MATERIAL } & \multicolumn{10}{|l|}{$\begin{array}{l}\text { TEMP. } \\
\text { OF USE }\end{array}$} \\
\hline & $F^{\circ}(C)$ & $\mathrm{SiO}_{2}$ & $\mathrm{AL}_{2} \mathrm{O}_{3}$ & $\mathrm{CaO}$ & $\mathrm{Fe}_{2} \mathrm{O}_{3}$ & $\mathrm{MgO}$ & $\begin{array}{l}\mathrm{K}_{2} \mathrm{O} \\
+\mathrm{Na}_{2} \mathrm{O}\end{array}$ & $\begin{array}{l}\text { ORGANIC } \\
\text { SUBSTANCE }\end{array}$ & OTHERS & $\mathrm{H}_{2} \mathrm{O}$ \\
\hline CAPOSITE & $1202(650)$ & 50.5 & 1.5 & 1.0 & 39.5 & 6.0 & 1.5 & NON & $\begin{array}{c}\mathrm{MnO} \\
1\end{array}$ & - \\
\hline $\begin{array}{l}\text { CALCIUM } \\
\text { SILICATE }\end{array}$ & $1202(650)$ & 44.2 & 33.5 & 4.2 & 3.1 & 0.5 & - & NON & - & 12.5 \\
\hline PERLITE & $1202(650)$ & 70.2 & 12.1 & 6.3 & 0.3 & $\mid 0.02$ & 9.0 & NON & $\begin{array}{c}\mathrm{MnO} \\
0.03\end{array}$ & 2.3 \\
\hline CERAMIC FIBER & $2372(1,300)$ & 43.2 & 55.0 & - & 1.0 & - & 0.6 & 0.1 & $\begin{array}{c}\mathrm{TiO}_{2} \\
(0.3) \\
\mathrm{B}_{2} \mathrm{O}_{3} \\
(0.6)\end{array}$ & - \\
\hline $\begin{array}{l}\text { MINERAL GLASS } \\
\text { FIBER BLACK }\end{array}$ & $1112(600)$ & 36.2 & 10.8 & 16.0 & 26.8 & 5.0 & 2.0 & 2.0 & - & NON \\
\hline $\begin{array}{l}\text { BLUE ASBESTOS } \\
\text { FELT }\end{array}$ & $932(500)$ & 50 & - & - & 20 & 2 & 6 & - & $\mathrm{FeO}$ & 4 \\
\hline
\end{tabular}




\section{SODIUM FIRE PROTECTION METHODS USED IN U.S. SODIUM FACILITIES}

Facility or Laboratory

Argonne National Laboratory

Lemont, lllionis

Atomics International

Canoga Park, California

EBR-11

Idaho

Enrico Fermi

Detroit, Michigan

General Electric

Sunnyvale, California

Hanford Engineering Division Laboratory

Richland, Washington

FFTF

Richland, Washington

Liquid Metal Engineering Center*

Canoga Park, California

Oak Ridge National Laboratory

Oak Ridge, Tennessee

SEFOR

Fayetteville, Arkansas
Principal Method

Reasonable gas-tight enclosures, some with manual inerting capability

NAX wheeled extinguishers

Inerted cell for primary sodium areas, Met-L-X piped system for primary sampling cells and secondary sodium system

Inerted cell for primary sodium areas, Met-L-X piped and hose reel system for secondary sodium system

Inerted cell for radioactive sodium areas; Met- $L$ $X$ piped and hose reel systems, self extinguishing enclosures for secondary areas

Air-filled steel enclosures with perforated plate and catch pans, some jumps and scrubbers with manual inerting capability. Wheeled Nax backup

Inerted cells for primary, steel catch pans and partially leak tight cells for secondary. Capability to inert manually with Nax for manual

Portable and wheeled extinguishers charged with Nax powder

Air-filled semi-enclosure with argon gas flooding capability, manual graphite powder backup

Inerted cell primary sodium areas. Portable and wheeled Met-L-X extinguishers for secondary areas

* Liquid Metals Engineering Center is now known as Energy Technology Engineering Center. 
Two experimental programs at the Liquid Metal Engineering Center (LMEC) are applicable to sodium fire protection problems. The compatibility of about a dozen commercial thermal insl 1 ation materials was investigated by pouring burning sodium at about $1058^{\circ} \mathrm{F}\left(570^{\circ} \mathrm{C}\right)$ onto them. All of the materials tested were subject to some degree of sodiun attack, but none sustained combustion after the sodium was consumed. The initial density of the materials tested ranged from 8 to $36 \mathrm{lb} / \mathrm{ft}^{3}$ $(0 . .3$ to $0.57 \mathrm{~kg} / 1)$. The time for flame initiation varied from 0 to 15 seconds and the time of burn varied from 26 seconds to 3 minutes. In general, the denser materials showed the least damage, the shortest burn time, and the highest flame. Conversely, sone of the less dense materials experienced the most volumetric damage, with the lowest flame height and lonclest burn time. However, the results are qualitative and only general conclusions can be drawn. If flame height and presience of incandescent particles are considered to be the most important criteria for safety assessments, the lightweight ceramic fiber and calcium silicate materials appeared to be superior.

\subsection{LEAK DETECTION}

$6.9 .1 \quad$ Background

Design of the facilities to mitigate fires and to fabricate piping and systems to high levels of quality assurance are vital to the successful operation of a system. Instrumentation to detect problems and actuate the engineered systems is an absolute necessity. There are a number of leak detection systems which have been around since the advent of liquid metals. Examples of these are spark plug and wire continuity systems. These are very simple. Many say there must be a more sophisticated way. However, a lot of world-wide effort has been put in to improve this technology, but only linited success has been realized. The key is the need for great reliability and the length of service required. These reasons, coupled with the inaccessibility for maintenance in many applications, provide the dimension of the problem. A good example of this new technology is the sodium ion detector.(48) This is an excellent instrument in principle. Its sensitivity is outstanding in that it can detect quickly even gram quantities of material in the atmosphere. The state-of-the-art probe 1 ife, however, is 1 imited to one year. These devices need periodic testing and calibration checks to assure continuing ability to function. orjginally, the radiation environment was thought to be a prcblem in the instrument application but this has not proven to be a problem. That it must be considered is evident, but the imfract has not been important.

6.9 .2 state of the Art

A table is included which enumerates the types of sodium detectors. The reference is from a Liquid Metals Engineering 
Center (LMEC) report(49) (see Figure 56). Figures 57(50) and $58(1 ; 3)$ show illustrations of some of the hardware. This sugciests a quantitative sensitivity noted from both testing at that. site and by developers and manufacturers. In addition, extensive tests have been conducted which attempt to determine the ability of the detector to discern between various burning materials. The question addressed is, can the detector actually tel.. if 1 iquid metal is leaking or does the presence of other material sinoke activate the system. There are some applications wituin the reactor requiring positive knowledge from a leak standpoint as opposed to a fire control viewpoint. One such plare is the guard vessel of the reactor core.

No particular reference will be made here to spacing of the detectors. The NFPA fire code (NFPA 72E) makes suggestions in this area. The individual applications will govern both in spa ilal distribution or spacing and in the height required. An interesting example of this is seen in the High Temperature Sodium Facility (HTSF) at Richland, Washington's, Hanford site. This is a very high bay building designed with a vessel to test full size components for the FFTF. In addition to this rig, a lot of fabrication and assembly work takes place in the building, with and without sodium. So the application suggests that a basic building system of smoke detectors as well as a special air protection device is needed to see any smoke presence. overhead or adjacent to the testing areas using sodium, a unique separate series of ionization instruments were applied to meet the special area applications. The same was true of the purification instrumentations rooms below the operating floor. Application of either photoelectric cells or ionization detectors was on a mini-area by mini-area basis. Reference to the codes will provide broad guidelines, but individual needs and judgement will be required to adequately apply the detectors to the system. It is well to mention here a very important point. The engineering application may be faultless and expert, but. the field testing and maintenance program will make the difference between success and failure.

It would be instructive to note that greater and greater emphasis is being placed on unattended operation of rigs and recictor systems. This is not to imply that operators are not avililable to service the systems. Rather, many tests depend upin automatic programmed system shutdown responding to real tine system operating conditions. It should be noted that "ir-place" control circuitry often give spurious alarm indicaticins. This occurs particularly as the systems are routinely checked for continuity by fire people. These spurious alarms sc am systems. Therefore, there is a tendency to adjust controls to less sensitive settings to prevent premature system shutdown. There is need for concern at this strategy. To be ef iective, it requires mature judgement, planning and cooperative action to deal with these problems without circumventing the fire control engineering system design. 
To provide an overview, information is presented which covers all the known leak detection schemes found in the 1 iterature to date.

\subsubsection{Description of Existing Types of Detectors}

The following is a review of presently available types of sodium leak detectors. (52) It was originally prepared by Becrtel corp. for the Fast Flux Test Facility program in conjunction with Liquid Metals Imformation center. All detector types are assumed to generic.

\section{LIQUID SODIUM DETECTORS}

A single foint detector consists of a pair of electrodes locited in the expected path of the leaking liquid sodium. The lealing sodium bridges the gap between the two electrodes and completes an electric circuit.

The electrodes are contained in an insulated metal fittincl. Such detectors are not commercially available as sodium leas detectors. There are two commercial items for this purpose (1) a spark plug or similar device, or (2) a thermocouple without a junction.

Spai:k Plug Detector

This detector is used under the main equipment components such as valves, pumps, heat exchangers, tanks, etc. The FFTF use: a spark plug version of the detector applied to each major component and at the low end of each piping insulation module. The inside surface of the insulation consists of a thin 1 ayer of stainless steel. A small trough is built into the bottom of the modilar insulation to direct the leaking sodium to the detector. spa:k plug detectors on main equipment components are installed in $\exists$ tube so that they can be retracted for inspection.

Despite its simplicity, a number of factors limit the suczess of this method:

Eleztrode wetting - Cood electrical contact requires wetting of the electrodes by the sodium. Clean surface and high temperature facilitate wetting. By "rule of thumb," the reliability of sodium wetting is uncertain at temperatures below about $5720^{\circ} \mathrm{F}\left(300^{\circ} \mathrm{C}\right)$ to operate electrical alarm circuits, such as those in a leak detector. Complete wetting or high-quality electrical contact is not necessary to operate circuits. The problem is in the uncertainty of contact which can result in intermittent signals.

Electrode spacing - Electrode spacing determines the amount of sodum needed to bridge the gap and close the electrical circuit. The minimum spacing is limited by the fossibility of an inadvertent short circuit caused by mechanical shifting of one or both electrodes. 
Detciured leak - Conditions can occur to cause a leak to follow a path other than the one leading to the sensor.

Leat: rate and total quantity of sodium leaked - A substantial quartity of sodium is "consumed" before any is available to actuate the sensor. The leaking sodium may be consumed by reaction with oxygen, hydrogen and water, by filling crevices and basins, and by wetting the surfaces it contacts.

Geonetry and dimensions - The amount of leaking sodium consumed depends on the geometry and dimensions of the surfaces involved.

Falise actuation - Some users find this method of detecting leaks to be satisfactory, but more report it to be unsatisfactory. The most specific complaints relate to accidental shorting with the consequent false alarms. The accidental shorting could occur from dirt, moisture accumulation, or other foreign substarces bridging the electrode gap.

Overall appraisal - It appears that the single point liquid sodium type detector is effective in detecting sodium leaks when the leak is of sufficient size to cause the sodium to flow to the vicinity of the detector.

Sensitivity - sensitivity tests performed at LMEC with the elestrodes protruded into the trough. It was 60 inches $(152 \mathrm{~cm}$ ) downstream from the leak hole. The trough had a slope of $1 / 32$ inch per foot and was insulated thermally so that its temperature was nearly as high as the test pipe temperature. The amount of sodium consumed enroute to the detector was found to be of the order of $0.21 \mathrm{~b}$ (100 grams). At a low leak rate of $0.05 \mathrm{oz}(1.5 \mathrm{~g})$ per hour, 67 hours would have been reached in order for the sodiun to reach the detector. At a rate of $0.4 \mathrm{lb}(160 \mathrm{~g})$ per hour, the sensor was activated within 37 minutes. During another test with a spurt of leakage, the response time was 54 minutes.

\section{Eddy Current Detector}

It consists of a high-frequency energized inductor placed in the path of leaking sodium. Sodium, entering the electromagnetic field about the inductor, absorbs electrical energy (by eddy-currents). The electrical circuits are designed to resipond to the energy change. It is used in the same way as the single point contact detector. This detector seems to have the advantage of not being susceptible to false alarms. There is no reported use of these detectors in existing sodium facilities. Commercial eddy current sensors, may be able to furction as sodium leak detectors if they can withstand the high temperatures involved. Models, custom designed and fabricated by LMEC, have been tested. Two tests were performed by LMFC. one was at a temperature of $1050^{\circ} \mathrm{F}\left(566^{\circ} \mathrm{C}\right)$, the other at $800^{\circ} \mathrm{F}$ $\left(427^{\circ} \mathrm{C}\right)$. The response times were 12 and 30 minutes, respectively. The detector performance was entirely satisfactory. 
However, this type has the same sodiun flow limitations under low temperature, high oxygen, and moisture conditions, as the electrical contact type.

Two wire Method

The two wire method consists of two parallel wires positioned on insulating material and shaped to assure exposure of the wire surface. The wires are part of an open electrical circuit and are placed along the bottom of the piping in the path of leaking sodium. Shorting of the wires by the sodium actuates the alarm circuit. It is used for detecting leaks on hor zontal sections.

The factors which affect performance of this method are the sam? as for the contact type. One significant difference between these types is the much shorter path the leaking sodium travels to activate the sensors and response time is lower and sensitivity is higher. This method is expected to be more subject to false alarms than the spark plug type. However, with a shorter leak path, it will be much more sensitive to sodium leaks.

\section{SODIUM VAPOR DETECTORS}

Sodium leakage into a hot environment produces sodium vapor as well as 1 iquid sodium and solid reaction products. It moves by diffusion. Vapor detectors require a continuous annular space over the length of sodium equipment or piping monitored if leas indication are to be found. These detectors function by response to sodium vapor by the following: (1) light absorption; (2) light emission; (3) plugging. (4) filters (moving and fixed); and (5) chemical methods.

\section{Atonic Absorption and Light Absorption Methods}

Here the substance, in an unexcited or ground state, absorbs radiation of specific wavelengths characteristic of itsılf. The wavelengths are those which are produced when the substance is excited. In general analysis, a wide $r$ ange of wavelengths is required. However, for a specific substance, as in the case of sodium vapor, a sodium lamp provides the required wavelengths. In this method of detection light from a sodium 1 amp traverses the region containing the vapor and passes to a light sensor (a photoelectric cell). The amount of light absorbed is proportional to vapor concentration and the path concentration and the path length through the vapor. Some forn of zeroing or checking circuits are added. In the Light Absorption Method, the photoelectric cell measures a reduction of light intensity. This is caused by the dispersion effect of the collimated 1 ight beam in the sodium smoke formed.

The absorption method of sodjum detection has a 1 imited application. The test data showed that sodium vapor cannot be 
generated and maintained under any of the test conditions long eno sgh to activate a detector. The vapor reacted with the environmental gas reactants, oxygen or moisture, forming sodium oxides and hydroxides.

The atomic absorption method has been described in work on the feasibility of leak-detection methods. Bench tests have been performed in an atmosphere containing less than $20 \mathrm{ppm}$ oxycyen but no use of this method in operation systems has been found.

In one design, a light beam from low-pressure sodium source trayerses the very low (20 ppm/oxygen inert gas) region to an optical detector cell (CdS). The threshold limit of sensitivity is $75 \times 10^{-6} \mathrm{~g} / \mathrm{m}^{3}$. This instrument is reported to perform well whe the leak is in the vicinity of the light beam. Another technique uses sampling tubes to convey the vapor from the region under surveillance to the optical instrument. This technique is capable of detecting concentrations as low as about $35 \times 10^{-6} \mathrm{~g} / \mathrm{m}^{3}$.

Light Emission Method - Here the substance is excited to produce radiation characteristic of itself. The radiation wavelengths show the identity of the atoms producing the radiation, and the intensity concentration. The sensor (a photoelectric cell) has a kroad wavelength response, so the wavelength is determined by passing the light through a monochrometer to resolve the wavelergths. The sensor output signal amplitude indicates the radiation intensity. The means of excitation include: flame, $r$ adio frequency, arc, spark, $x$-ray fluorescence, and neutron activation. The most common form of excitation, and the only form used for sodium leak detection, is the flame. This technicue is commonly known as flame photometery. Sodium is easily iorized in a flame, emitting a characteristic yellow 1 ight, the principal radiation being at $5.89 \times 10^{-7} \mathrm{~m}$. The wavelength resolution requirements for leak detection generally are not rigorous. Therefore, an instrument of considerable simplicity, compared to the typical analytical instrument, is satisfactory. The flame will decompose sodium compounds, and thus the flame method will be effective in detecting smoke which is essentially particles of sodium oxide.

An open flame is generally regarded as undesirable in an operating area and its use as a means of excitation may be particularly undesirable for sodium leak detection. Possible unclesirable problems associated with combustion products may be a disadvantage of this method. However, it has a potential for on-1ine use if sufficient products can be conducted to a stationary chemical laboratory.

No reports on a method using flame photometry directly fo: on-line sodiun leak detection were found. other techniques using other means of excitation are not sufficiently developed for immediate use. Flame photometry was used to 
analyze phenolphthalein and water solutions through which gas was bubbled in the LMEC tests.

The rnethod is very effective for absolute analyses of gasborne sodium components.

Instruments for detecting sodium vapor are proven and commercially available. They are very sensitive, having a threshold limit of $5 \times 10^{-3} \mathrm{~g}$ of $\mathrm{Na}$ per cubic meter of air. However, these instruments are not recommended for sodium leak detection since an open $f l a m e$ is undesirable in operational provess areas.

Pluyging type detector - A plugging type detector consists of a tapjed gas line running from the annular space surrounding pipe or iquipment (i.e. between the component and the insulation), to whish a device with a restricting gas passage is attached. The gas 1 ine runs to a flowmeter measuring the continuous flow of gas. When a sodium leak occurs sodium oxides tend to plug the restricting gas passage and cut the flow of gas. The flowmeters senses the gas flow reduction and thereby indicate a sodium lear.

This detector was found during a laboratory test to be as resjonsive to sodium leaks as any other detector. However, it may require additional operational testing in simulated process systems to define the required characteristics of detection in order to prove the success of its application as an operational sodium leak detector.

No record of the use of this method in operational systems could be found.

The factors which were expected to affect the performance of zhese detectors were:

(a) Temperature of the leaking sodium and the leak environment. The formation of vapor and the reaction of sodium with oxygen, hydrogen, and moisture in the environmental gas, increases with temperature. Therefore, the higher the temperature, the greater the production of plugging material.

(b) Supply of gas reagents. A sufficient quantity of gases which can react with the leaking sodium must be available to produce an adequate quantitiy of plugging material. The moisture content of the environmental gas should be the main factor since the moisture produces plugging material and enables the reaction of oxygen and hydrogen with sodium.

(c) Reaction product driving force. Only those products which are suspended in the environmental gas and are carried to the sensor can contribute to the plugging. 
(d) Plugging detector threshold sensitivity. The geometric factors which affect the sensitivity have been only partially investigated.

(e) Length of transmission line. Deposition of sodium and its compounds within the transmission 1 ine reduces the amount material which can be available to contribute to plugging unless the plugging orifice is located at the input to the 1 ine.

(f) Plugging detector selectivity. Material other than the sodium leak generated products may deposit in the orifice and cause plugging, causing a false leak indication. This type of false alarm right be found to be prevalent with the plugging detector in process systems. However, corn starch did not plug the detector in the tests. Potential for foreign particulate material in the actual operating environment must be made in order to assess the applicability of this detection method, particularly if it is to be used to identify locations of leaks.

The behavior of the four models made and tested by LMEC differed somewhat in their plugging characteristics. However, within this limited range of testing, no clearly discernible feazure which would indicate the "heat configuration or dimensions" was evident. The effectiveness of all forms of the device in detecting leaks was nearly the same. That is, plugging to 908 of flow immediately following visual indication of $\exists$ sodium leak. The plugging devices responded satisfactorily except in three of the $4000^{\circ} \mathrm{F}\left(204{ }^{\circ} \mathrm{C}\right)$ and one in the $500^{\circ} \mathrm{F}$ $\left(260^{\circ} \mathrm{C}\right)$ tests. They responded satisfactorily in one of the $400^{\circ} \mathrm{F}\left(204^{\circ} \mathrm{C}\right)$ tests. From these results it appears that the sensitivity of this type of detector is limited to operation in systems of temperatures above $500^{\circ} \mathrm{F}\left(260^{\circ} \mathrm{C}\right)$, if in a relatively inert atmosphere.

A cursory experiment was performed by LMEC to determine the susceptibility to plugging by particles other than sodium leak prcducts. When a dust of cornstarch was used no plugging occurred. In several tests performed to unplug a sodium oxide plug, unplugging was readily accomplished in all cases but one. 'This was a plug formed under high moisture conditions and was the only case of complete orifice plugging.

The plugging detectors were not tested at the end of the $50-$ foot $(15 \mathrm{~m})$ line since the most efficient position is at the inlet to the 1 ine. Other test data had shown that a substantial amount of the plugging material deposits in the 1 ine. In one test the amount of material reaching the detector through a $50-$ foot $(15 \mathrm{~m})$ line was 40 of of that which reached the detector through a 9 -foot 1 ine. 
Filter Type Detector (moving and fixed) - A fifth type detector uti.izes an arrangement of a moving or fixed filter together with a flow indicator. This arrangement is connected to the gas line coming from the annular space between the sodium piping and the insulation. During a sodium leakage the sodium vapor and sodium oxide become suspended in the gas and are carried to the filter. The filter removes the particulate constituents from the gas stream and retains them. This continuous build up of particulates of sodium and sodium oxide on the filter restricts the gas flow. An indication of this restriction in the flo' is monitored by the flow indicator.

This detector seems to be responsive to sodium leaks. It has possibilities for use in sodium leak detection by either monitoring the annular space surrounding piping and components or as a gross check on a cell where the filter type detector would be placed in the cell exhaust 1 ine. However, operational tests should be made to define its characteristics for sodium leak detection when connected to a process 1 ine. No reported use of this method in existing sodium facilities could be found.

The factors which seem to affect the performance of this detector are essentially the same as those identified for the plugging type detector. However, this method will tend to plug more rapidly than the orifice type due to foreign particles. Thus the filter must be placed at the outlet of the transmission line located at $100 \mathrm{ft}(30 \mathrm{~m})$ while $90 \%$ line desposition losses or more are predicted to occur. On the other hand, accessibility to the filter for replacement and chemical analysis may be a distinct advantage. Since no tests have been conducted there is no basis for factual evaluation of this concept.

No recorded sensitivity value is available. Previous experience with air filters, however, indicates that this method of detection would probably be more sensitive than the plugging type method. The filter method is subject to false alarms from dirt accumulation in the same manner as the plugging type.

\section{CHEMICAL DETECTORS}

Chemical Analysis Method - In this method, a tube carries the vapor from the region under surveillance to a detector corsisting of a solution of a reagent which responds to sodium. LMEC made and tested a detector using a phenolphthalein soluticn. The sample of the environmental gas was bubbled through this solution to detect either sodium vapor or airborne sodium oxide particles. Although phenolphthalein will discolor, it varies with the concentration of the solution. This depended upc $n$ chemical analysis for evaluation of sodium content. Gas volume flow-through was measured very carefully to determine the: average sodium concentration in the gas during the duraticin of the test. Good response led to continued use of the phenolphthalein solution during the remainder of the testing 
propram. After completion of each test, the phenolphthalein solution was analyzed in the laboratory by $f l$ ame photometry for quantitative data on the amount of sodium in the environmental gas. The laboratory analysis greatly increased the sensitivity of this method and eliminated the uncertainties involved in detacting the appearance of a pale color. The same type of aetactor can utilize a solution of thymol blue in place of phenolphthalein.

The phenolphthalein solution indicated a sodium leak in each test conducted. It is difficult to discuss the response timı of this instrument since the color change is slight and is very gradual. Also, in some cases, no color change was discernible but the detection was verified only upon laboratory analysis. Another factor is that the effect is cumulative, i.e., the longer the gas is bubbled through the solution the more sodium is collected for detection. This detector cannot be utilized as an on-line leak detector since the solution has to be taken to the laboratory for analysis. No published data are available on the performance of this method in operating sys zems.

The factors which were expected to affect the performance of $=h$ is method were:

(a) Temperature of the leaking sodiun, as discussed previously for formation of vapor and reactants.

(b) A supply of reactants such as oxygen, hydrogen, and moisture in the environmental gas must be available to produce an adequate quantity of airborne material. The moisture content of the environmental gas should be the main factor since the moisture produces sodium compounds and enables the reaction of oxygen and hydrogen with sodium.

(c) Reaction product driving force. Only those products which are suspended in the environmental gas are carried to the sensor.

(d) Chemical indicator selectivity. Material other than the sodium leak, generated products that may activate the sensor unless a chemically selected sensor is used.

(e) Chemical indicator sensitivity. The responses of the chemical indicators are cumulative, i.e., the longer the gas is passed through the indicator the greater the indication.

With a phenolphthalein solution a successful operation at the end of a 50-foot transmission line was demonstrated. In one test with a gas flow rate of $0.18 \mathrm{in}^{3} / \mathrm{min}(3.0 \mathrm{cc} / \mathrm{minute})$, and a flow duration of 57 minutes, the sodium concentrations in the 
cells were $1860 \mathrm{ppm}(\mathrm{w})$ at the end of a 9 -foot $(3 \mathrm{~m}) 1$ ine, and 736 $\mathrm{ppm} / \mathrm{w})$ at the end of a $50-$ foot $(15 \mathrm{~m}) \mathrm{line}$. It is evident that a sustantial amount of material was deposited enroute. However, the amount, $736 \mathrm{ppm}$, which was available for detection is well. above the detection threshold linit. With a thymol blue solution, a concentration as low as $2.3 \times 10^{-4}$ grams of $\mathrm{Na}$ per cubic meter of nitrogen carrier gas could be detected. This metrod is not considered practical for temperatures below $482^{\circ} \mathrm{F}\left(250^{\circ} \mathrm{C}\right)$.

However, when the absorbing solution was analyzed by flane photometry, detection was effective over all temperature environments tested at LMEC; i.e., as low as $400^{\circ} \mathrm{F}\left(204^{\circ} \mathrm{C}\right)$.

$\mathrm{pH}$ Method - Defined as the negative logarithm of the activity of the hydrogen ion, $\mathrm{pH}$ is the measurement of acidity or alkalinity of an aqueous solution.

Instrumental measurement of $\mathrm{pH}$ is made by immersing a special glass electrode and reference electrode into the solution. The glass electrode produces an electrical potential dependent on the activity of the hydrogen ion. The reference eleatrode completes the circuit and furnishes a stable reference potential for comparison against the glass electrode potential. The difference in potential between the glass and reference electrode is directly proportional to the solution pH. A. thermocompensator is usually immersed in the solution to automatically compensate for the glass electrode's millivolttemperature relationship.

For industrial process pH measurement, the glass electrode, reference electrode, and thermocompensator, are usually placed in an electrode chamber which is installed in a sample 1 ine, or submerged in a tank or trough. The voltage developed at the electrodes is measured by a stable precision ampliffer and read out as $\mathrm{pH}$. Outputs from the $\mathrm{pH}$ analyzer may be connected to recorders and/or controllers to achieve continuous $\mathrm{pH}$ control of a process.

LMEC tested this method of sodium leak detection using a Beckman Research pH meter with a non-selective ion electrode. This instrument provided a continuous indication of the sodium in the environmental gas when collected in a distilled water solution.

The $\mathrm{pH}$ indicator is a commercially available instrument. It can be used for on-line operation. When a sodium electrode is added to the instrument, the $\mathrm{pH}$ detector becomes responsive to sodium. Consequently, leak detection by gas sampling and sensed by a sodium ion electrode pH indicator is a suitable mezhod, when slow time response and extensive sampling is acceptable or where leaks in low temperature systems must be detected. No published data are available on the performance of the instrument in operating systems for sodium leak detection. 
The factors affecting the operation of this detector are substantially the same as those affecting the operation of the chemical analysis method. Hence it is safe to assume that it will detect leaks over the same range shown for the phenolphthalein solution. This detector needs water supply and some careful attention. It has slow response and it is difficult to automate.

The concentration of sodium in the cell is a function of the sodium concentration in the sampled gas, and of the length of time the mixture is bubbled through the water bath of the $\mathrm{pH}$ instrument. Consequently, the threshold sensitivity increases with bubbling time. As an example, in one test by LMEC the $\mathrm{pH}$ at the time the leak was initiated was 6.78 and 28 minutes later was 9.30. The Backman Research pH Meter was found capable of indjcating changes as small as $\pm 0.0005 \mathrm{pH}$. However, such a small change could not be regardē as the indication of a leak. Additional investigation is required to establish the change whic:h could be regarded as a true indication of a leak.

With a pH meter having a sodium ion electrode, measurenent of the sodium ion activities could be made over at least four decades of concentration, but this electrode also responds to silver and lithium ions. This electrode is used for general laboratory applications where sodium ion activities are of interest. A commercially available industrial type sodium ion elertron $\mathrm{pH}$ meter can measure in the range of $1 \mathrm{ppb}$ up to 1000 $\mathrm{ppb}$.

Conductivity Method (Specific Ion) - In the conductivity method, the sample of gas is drawn from the region under surveillance and the gas is bubbled through pure water. Any sodium in the gas sample will react with the water and produce several reaction products, which result in an increase in the ionic conjuctivity. To minimize the possible effects of environmental variations causing conductivity changes, a pair of identical cells are exposed to the same environment but with sample air bubbled through only one cell. The two cells are connected to the electrical circuit so that an imbalance created by a change in conductivity of one produces a signal. This analytical technique is applicable to detection of sodium smoke or sodium oxide as well as vapor, since sodium smoke will produce an easily detected reaction in a conductivity cell. This method can be utilized for on-line leak detection. No published data are available on the performance of this method in operating sodium systerns. However, extensive data are available on the performance of detecting sodium in fossil fuel plant cooling water as a result of condenser leakage of sea water.

The factors which are expected to affect the performance of this detector are the same as those which affect the performance of the chemical analysis method. This detector needs water supply and some careful attention. It has slow response and it is difficult to automate. The concentration of sodium in the 
cell is a function of the sodium concentration in the air and the length of time the mixture is bubbled through the water. Consequently, the threshold sensitivity increases with bubbling time. A commercial conductivity detector has a sensitivity of measurement of $1 \mathrm{ppb}$ of $\mathrm{Na}$ or 10 Mho of conductivity.

\section{RADIATION DETECTORS}

When natural sodium $23 \mathrm{Na}$ has been neutron activated, forming $24 \mathrm{Na}$, the strong gamma radiation from the sodium provides an additional means of detection, the use of gamma radiation sensors. The common situation in which $24 \mathrm{Na}$ is formed is in sodium used to transfer heat from a nuclear reactor core. The radioactive sensing method of leak detection is commonly used for the primary loop of a nuclear reactor. Any leak results in at least a trace amount of vapor or smoke released to the atmosphere. Since a loop carrying radioactive sodium (or the primary system of a reactor) is enclosed and controlled forced ventilation is provided, the common method of sampling is to monitor outside the sodium cell from the recion surrounding the sodium equipment and piping (annular space).

The detection system utilized for this purpose is an airborne particulate monitor attached to a vacuum system. This moritor has the task of collecting the particulates from a large volume of gas and concentrating them onto a small collecting arta, or an air filter, where a detector measures the amount of racioactivity in the particulates built up on the air filter. The air filters applicable to sampling airborne radioactive particulates have an efficiency of about 998 for particle sizes of less than a micron. More efficient filters are available. The air filters are of two types: 1) a fixed air filter; and 2) a moving air filter. The detector responds to the activity of the accumulated radioactive particulates on the filter and sends signals to the attached electronics which trigger the alarm unit indicating a radioactive sodium leak in a particular area.

Particulate monitors have been utilized in nuclear power pliants. They are used to monitor the radioactive particulate concentrations in the effluents of the process systems and in the effluents released into the environs. They will be utilized in the FFTF to monitor the airborne radioactive particulate concentrations in the breathing air inside the nuclear facility for personnel protection. There are numerous reports which describe favorably the usefulness of the particulate monitor in operational application for radioactive particulate monitoring in nuclear power plants.

The factors which seem to particulate monitor for sodium some of the factors pertinent mentioned in section (b). These affect the performance of the leak detection are 1 imited by to detection of sodium vapor factors are: 
(1) Temperature of the leaking sodium, the environment, and the gas transmission 1 ine to the detector.

(2) Leak rate and total quantity of sodium leaked.

(3) Vapor transport driving force.

(4) Detector threshold sensitivity.

(5) Length of the transmission line.

(6) Ambient gas disturbances.

(7) Diffusion and activity of the sodium.

This method of radioactive particulate monitoring is app.icable only for detection of radioactive sodium.

\section{SMOKE DETECTORS}

Sodium smoke or sodium oxide may form as the consequence of sodium burning as it leaks, or in the conversion of sodium vapor to smoke as discussed in previous sections.

A number of smoke detection methods can be applied. One method of detection, the Light Emission Method, described in a preyious section to detect sodium vapor, can be utilized for sodium smoke detection. The operating principle is somewhat difeerent in that the light traversing the smoke is scattered rather than absorbed. The wavelengths in the light are not significant.

One technique used is based on the change in current in an ionization chamber as the result of smoke particles. Two identical ion chambers are used. They are connected in a bal anced electrical circuit, and placed so that both are in a similar environment; but one is exposed to the sampling region and the other is protected from smoke. A voltage is maintained across the electrodes and an ion current is maintained by an alpha emitter (a minute amount of $r$ adium). The presence of smoke particles in the exposed chamber reduces the current flon causing a voltage difference which energizes the electronic cirzuit that operates the alarm.

An improved type of photoelectric fire detector (one design is interchangeable with the ionization type) is now commercially available and this instrument does not appear to have some of the previously described disadvantages of the ionization detectors. In the photoelectric detector, smose particles entering the chamber are illuminated, and the scattered $1 \mathrm{ight}$ from these particles reaches the photocell causing an alarm. 
A number of smoke detection methods are possible and some methods have been applied for leak detection in several operating sodium systems. Also, some of the vapor detection instruments can respond to smoke.

The photoelectric detector may be used for applications in which it is not practical to use ionization detectors due to high ambient concentrations of combustion products and in which the material expected to burn produces a dense visible smoke. This method of detection has a possible application in secondary sodium systems which are located in air environment.

Commercial smoke detectors are used in a number of sodium installations. Their rather widespread usage probably is due to their comnercial status, availability, and ease of installation, ratrer than demonstrated performance as sodium leak detectors. No :substantial body of performance data on the smoke detectors has been published, but oral reports indicate disappointing performance in some cases often thought to a result of bad postitioning.

Smoke detection is 1 imited by some of the factors pertinent to vapor and these are: (1) the need for the conditions for smoke formation (i.e., moisture and oxygen in the atmosphere), (2) ambient atmosphere disturbances; and (3) diffusion (transpor $=$ ). The discussion of disturbances and diffusion as they affect transport was covered in previous sections on vapor. These are also applicable to smoke.

\section{Ionization Detectors}

Ionization chamber detectors may produce false alarms. These are caused by changes in ambient conditions and by detection of dust or other particles not related to a leak. Therefore, this method often requires a back-up system using another method of detection in order that monitoring can be done during the reactor startup or when the sodium activity is below normal due to reactor shut down.

Because of the ability of the particulate monitor to concentrate the activity from a large volume of gas, it can provide very good sensitivity. A commercially available particulate monitor using a scintillation detector has a sersitivity of $8 \times 10^{-10} \mathrm{C} / \mathrm{cc}$ of $137 \mathrm{Cs}$ in a background of $2 \mathrm{~m} / \mathrm{R} / \mathrm{r}$. The radiation shielding used for this monitor is 4 inches $(10 \mathrm{~cm})$ of lead.

Commercial ionization detectors require routine maintenance anc calibration. They are relatively insensitive to sodium oxide smoke (smoke densities that are readily detected visually may not actuate the ionization detector). The detectors should be located very near the potential fire site and must be in the veritilation airflow in order that the time delay in detecting the fire be a minimum. This may create a problem in large 
spaces where there is no specific pattern of airflow, and actual location of fire in a complicated or modified system may not coincide with the fire location predicted when the detector was installed. Furthermore, the ionization detector is quite sensitive to normal smoke and combustion gases (for example, from a welding torch), and this sensitivity often results in false alarms. Because of this problem, these detectors are frequently installed in a compromise location, or the sensitivity of the detector is reduced to a point that its value as a sodiun fire detector is severely 1 imited.

The detection by means of an ionization chamber has a threshold sensitivity of about $0.1 \mathrm{~g} / \mathrm{m}^{3}$ but this sensitivity is 1 imited by the onset of false alarms caused by other particles. Preliminary tests by the ANL Fire protection Department indicate that the photoelectric detector has much greater sensitivity to sodium oxide smoke than the ionization detectors and is recommended for installations where sodium or other smokeprocucing metals might be the prevalent type of fire. However, the location of the photoelectric detector must also be selected witr care.

\section{HYDROGEN DETECTORS}

The use of a hydrogen sensor as a sodium leak detector is luased on the generation of hydrogen as the result of the reaction of water (moisture) in the environmental gas with the lealing sodium.

The general operating principle is as follows: an evacuated tube, closed at one end by a palladium or other suitable membrane, is placed in the carrier gas stream. The tube contains an electron emitter and anode. Palladium, being permeable to hydrogen, permits the passage of hydrogen into the electrode region. The hydrogen passed is ionized in the electrode region and the resulting ion current change indicates the presence of hyd::ogen.

LMEC tested this method of sodium leak detection using a hydrogen detector connected to the test apparatus through an unheated, 12 -foot $(3.7 \mathrm{~m})$ long, $1 / 4$ inch $(6.35 \mathrm{~mm}) \times 0.035$ inch $(0.9 \mathrm{~mm})$ wall stainless steel tube. The sample point was 9 inches $(22.9 \mathrm{~cm})$ downstream from the leak hole. On the basis of this test program, LMEC concluded that the hydrogen detector could be expected to provide satisfactory performance as a leak detector except under the following conditions:

(a) High hydrogen concentration background. In these tests the required test range was $0-2$ o hydrogen. A specific effort to provide the hydrogen background was not made. However, the important results relative to this factor were obtained. In most tests, the amount of hydrogen generated caused sensor saturation at least temporarily. In some tests, the recovery time 
was substantial, hours and sometimes days. A hydrogen concentration of $2 \%$ was found to saturate the instrument. It was found that the instrument could not function as a sodium leak detector at hydrogen concentrations even approaching $28(20,000 \mathrm{ppm} / \mathrm{v})$. All tests were conducted at concentrations of only a few ppm. The concentration at which operation becomes impractical was not determined.

(b) Low temperature. In these tests, a temperature range of 400 to $1050^{\circ} \mathrm{F}\left(204\right.$ to $\left.566^{\circ} \mathrm{C}\right)$ was required. Th is range was covered. At $400^{\circ} \mathrm{F}\left(204^{\circ} \mathrm{C}\right)$ and at $0.06 \mathrm{oz} / \mathrm{hr}$ $(1.5 \mathrm{~g} / \mathrm{hr}$ ) liquid sodium leak rate, no response was obtained under any of the environmental gas conditions.

No published data are available on the performance of this method in operating systems for sodium leak detection. However, the factors which seem to affect the performance of the hydrogen leak detector are the following:

(a) Temperature of leaking sodium and leak environment. The chemical reaction rates increase with temperature.

(b) Leak rate and total quantity of sodium leaked. The amount of hydrogen generated is 1 imited by the available sodium surface.

(c) Moisture content of the environmental gas. The moisture, $\mathrm{H}_{2} \mathrm{O}$, reacting with the sodium is a source of hydrogen.

(d) Hydrogen content of the environmental gas. The oxygen reacting with the leaking sodium and sodium vapor will form sodium oxide and this. will interfere with the hydrogen generation.

(e) oxygen content of the environmental gas. A hydrogen detector sensitive enough to detect hydrogen from small sodium leaks would be saturated if a high hydrogen background exists. Also a detector which could accommodate a high hydrogen background may. not be capable of a hydrogen concentration increment of the size caused by a small sodium leak.

(f) Hydrogen transport driving force. Although hydrogen diffuses readily, the transport is assisted by the environmental gas flow to the detector.

(g) Conditions which permit preservation of hydrogen during its transport form the leak region to the detector. The sodium-hydrogen reaction is reversible. Hence, under some conditions the hydrogen could 
react with sodium and thereby reduce the amount of hydrogen available to actuate the detector.

(h) Hydrogen detector threshold sensitivity. This value limits the minimun detectable leak capability.

(i) Hydrogen detector selectivity. Response to some stimuli other than hydrogen could cause a false al arm.

The test performed by LMEC showed that this detector was found to respond rapidly, usually within a few minutes after the leak was initiated. However, the signal was affected by the gas flow rate. During each test, a constant flow rate was maintained. The rate was $12 \mathrm{in}^{3} / \mathrm{min}(200 \mathrm{cc} / \mathrm{min})$ for 10 tests and $6 \mathrm{in}^{3} / \mathrm{min}(100 \mathrm{cc} / \mathrm{min})$ for 4 tests. No recorded value is found on the sensitivity of this hydrogen leak detector.

\section{THERMAL DETECTORS}

Thermal contact of leaking sodium with a thermal sensor can be used as the basis for a leakage indicator. Good thermal contact is advantageous, but the contact requirements are less stringent than those for the electrical contact method. The disadvantage of the thermal method is that heat transferred from the sodium is negligible for very small leak rates and may be negligible in other circumstances. The sensors may be used in the manner described for electrical circuits, i.e., point sensors mounted in drip pans or other sodium receptacles, or may be distributed as indicated for wire sensors. A conventional thermocouple is an example of a thermal sensor for point detection service. For monitoring a line or an area, a special form of thermocouple can be used. This consists of a cable containing a pair of thermocouple wires insulated by an insulator having a negative temperature coefficient of resistivity. A high temperature at any point or region along the length decreases the resistance of the insulation at the point to a low enough value that the point becomes a thermocouple junction.

The use of thermal sensors for leak detection is marginal. This method is probably restricted to special circumstances.

\section{SPECIFIC CHEMICAL DETECTORS}

This method requires a reagent which can be suitably dispersed in the region under surveillance so that any leaking socium will contact it. The contact between the sodium and the recigent should produce a readily detectable reaction product.

The reaction of methyl alcohol with sodium to produce hyorogen is an example of this technique which was developed to delect leaks at temperatures below the range of successful operation of vapor detectors. Although developed for a NAK 
system, it is applicable to sodiun systems. The ambient atmosphere consists of an inert gas that contains some methyl alcohol vapor. The alcohol vapor reaction with leaking sodium produces hydrogen, a product easily detected by means of proven commercial sensors. The method was reported to be satisfactory in bench tests, but the lack of leaks during use on a system prevented a complete evaluation.

The reaction of ammonium compounds with sodium releases fret: arnmonia which can be detected in several ways. This method uses: an ammonium sulfate compound at the probable leak areas. However, the ammonia released by thermal decomposition of the ammonium sulfate due to the high temperatures of the examined areas produces high ammonia concentration in the environment without the presence of alkaline compounds. This high background ammonia level makes the detection of small increases due to the presence of $\mathrm{Na}_{2} \mathrm{O}$ impossible, and the method has not been explored further. Other methods based on adding a specific reajent to form a reaction product have not been developed or leven considered to any significant extent.

\section{INERA-RED AND ULTRA-VIOLET DETECTORS}

These utilize on-line light sensors which are triggered by the hot sodium leak. There is little information on this type of application. Infra-red photography has also been used to detarmine temperature distribution in arrays of piping. This method might be adapted to sodium leak detection but no data is known.

\section{SOLII) STATE DETECTORS}

This is a solid electrolyte. This device is in the very early stages of development and no satisfactory evaluation of it car. be made. It is intended that the detector be placed in the gas annulus or in sample lines. It would respond to sodium licluid or sodium vapor as its electrical conductivity is affected by the presence of sodium.

\section{MISCELLANEOUS DETECTORS}

Visual and olfactory detection - Visual and olfactory identification of the dense oxide smoke formed when alkali metals burn are sensitive and common methods used for fire detection. Because the commercially available automatic detectors are much less sensitive, the operators of even large, expensive alkalime:al systems rely heavily upon the visual detection of a fire. Visual fire detection demands that personnel are within view of the sodium fire. The complexity of a reactor plant and the inaccessibility of totally enclosed experiments precludes the possibility that all sodium fires will be visually detected in time to prevent significant plant damage. For this reason, automatic detectors must be relied upon. 
Tel $\epsilon$ Vision monitors - A modification of visual fire detection is the use of closed-circuit television. At the ANL Illinois sita, such a system is used by a two-man crew to monitor sodium operation between Buildings 206 and 308 . In this application the two-man shift is required at only one building. The TV monitor can be used by men at either site to monitor unat:tended sodium operations at the other site. The use of a TV mon:tor to view one or more remote locations does not demand that: an operator watch the monitor continuously, as electronic circuits have been developed to give alarm signal when the scene changes. Thus the appearance of smoke or fire would constitute a change and sound an alarm. ANL has experienced practical problems in the maintenance of the TV monitor. For example, a TV monitor, in itself, can give more operational problems than the sodium system that the monitor is supposed to view. In addition, a single TV monitor has a limited field of view. A monitor focused to observe one small area in great detail cannot view a large area at the same time. Conversely, a monitor foc ssed to give a very wide field of view may not detect a small fire until the small fire has become large.

Laser methods - In this method the monochromatic laser beam is irected across the room to a mirror and reflected to a photo eleztric cell. The particles of smoke affect the beam intensity. This has been proposed and tested for large reactor cells where long area spans are required. It can be affected by being sensitive only on a very narrow area hence missing changing conditions caused by chimney effects.

\subsection{CODES AND CALCULATIONS}

Some very excellent work has been done over the years in the area of fire calculations and modeling. They have been required for the safety evaluation assessments and for design necessary to contain the design base accidents postulated for the nuclear island. It is important to be aware of these for they are valuable tools to fire control engineering design.

Among other things, they predict with accuracy, the actual conditions present in the nuclear island in the event of emergencies. Though they have been devised for worst case corditions, they might well lend themselves to more conventional application in the design of rigs for testing. They can give corsiderable insight to design parameters; e.g. maximum temperature rise, the amount of airborne material, and pressure risies. They likewise provide insight into the quantity of $r$ ac ioactivity to be handled in these situations. Previously, aprlication of these codes by fire control engineering people has; been limited because they were developed by reactor safety peciple. It appears that application would provide fire people greater insight in the design and handling of fire related events. For reference purposes, we have extracted a paragraph from some excellent review reports of recent date to provide an overview of this work area. $(53,54)$ 
The design of a Liquid Metal Fast Breeder Reactor (LMFBR) is based upon the philosophy which places the highest importance on cchieving a safe and reliable operating plant. An important part. of the design and safety assessment of an LMFBR is the analysis of potential and/or postulated sodiun spills, resultant fires, and their consequences.

In analyzing the consequences associated with the sodium spil.1s, it is necessary to establish the potential for such spills and modes of discharge. The structural analysis along with fracture mechanics must be utilized to evaluate the possible failure modes and consequent sodium spills. The range of these sodium spills could extend from dropwise sodium leakage thrcugh small cracks up to large, massive spills due to postulat $\epsilon$ d large pipe breaks.

In the case of a leak or a coolant piping break, the initial phase of the resultant sodium spill is likely to be a pressurized jet or spray. The characterization of sprays, formation of the drops and associated droplet diameter determinations, along with combustion and heat transfer are the important steps in analysis of the spray fires. After the init:al phase of the discharge in the form of a jet or a spray, the sodium from the system would drain out and eventually col..ect as a pool on the floor of the containment cell. The quantity of the sodium drained and the size of the pool subsequently formed will depend upon the size and location of the rupture in the system. The resultant temperature/pressure transients which are functions of the sodium burning rate, sodium temperature, rate of heat generation and oxygen consumption are the important aspects of the pool burning phase of the sodium fires.

The currently available codes for analyzing sodium spray fir as are: SPRAY-1 and 2 and SOMIX-1. SPRAY-1 and SOMIX-1 are intended for low oxygen environment, while SPRAY-2 is intended for air environments. With careful application and using the codes in conjunction with each other, spray fires in low oxygen environments could be adequately analyzed. For air zone spray fires, it is presently felt that reasonable results can be obtzined with SPRAY-2. SOMIX-1 is expected to be an advanced code for analyzing spray fires. However, there is need for verification of the codes.

In the area of pool fire analysis, SOFIRE II code found to yield good results. There is considerable experimental data available in support of this code. To achieve good results with SOFIRE II there are several important parameters that significantly affect pool fire calculations. These are values for the coefficients in the mass transfer correlations, monoxide/ peroxide ratio and the radition emissivity factors.

CACECO is a large, multi-cell and multi-purpose code. The coding was extensive so as to facilitate detailed modeling of 
several simultaneous effects, such as: sodium burning, sodium vapcr condensation ("rainout") into the pool, and evaporation ("bcil-off") from the pool. The mass balance treatinent include the effects of atmospheric leakage and venting. The treatment of the energy balance consists of, in addition to the sodium comoustion, the effects due to the fission product decay hearing, space coolers and associated heat transfers. The cACrCo code was used to analyze sodium fires steming from spray and pool formations in both low and high oxygen environments.

A version of the NARX code was received and made operatioral on the CDC-7600 computer at LBL, Berkeley. Several sample cases have been executed successfully. The NARX code is a soray fire code to be used for analyzing the spray fires in higlier oxygen ( $>4$ vol $\%$ ) environments.

In conclusion, it is found that there is no one single code available to analyze the entire spectrum of anticipated or posiulated sodium fires. However, with careful application and using the codes in conjunction with each other, CACECO, SOFIRE, and SPRAY, in our opinion, are most useful tools for predicting the pressure/temperature effects of a sodium fire in a low oxyiyen cell. It is believed that the on-going experimental and analytical programs will provide necessary information to calibrate and further refine these codes. This will help in performing more realistic calculations and reduce the undue conservatism that is presently required.

It is instructive to describe work of the French AEC on the mechanism of liquid metal fires. Though this was conducted from the physical chemists viewpoint, it gives insight into the actual fire chemistry and suggests what parts of the chemical system can best be attacked. For example, their work suggests that the crust of oxide formed is the point that can best affect the control of the fire. In fact, Met-L-X (NaCl) and NAX $\left(\mathrm{Na}_{2} \mathrm{CO}_{3}\right)$ essentially attack at this point. However, the specific gravity (weight of the reagent) makes some difference. If the crust is not built up, the weight of the extinguishing reagent applied will break through and not reinforce the crust. In this situation, application of the reagent to build the crust is of vital interest to the fire fighter. The practical fire fighter quickly learns the technique of application to maximize that crust which acts as an oxygen barrier.

\subsection{DETAILS OF ENGINEERED FEATURES OF CONTAINMENT SYSTEMS}

It is easy to state some of the principles, it is another thing to suggest ways in which these may be applied with respect to detail. We will attempt to reflect through the use of figures, the experience that has been developed throughout the free world. We have reason to believe these same types of corfigurations exist in the several liquid metal cooled soviet reactors, but we have no details. 
Penetrations are necessary between compartments to maintain barrier integrity and to prevent contamination flow. Several details are presented (see Figure 59). (55) They indicate, in general, the use of bellows to accomnodate pipe expansion and allcw movement as well as a tendency toward double containment of the pipe. In the case of wiring, for power or control, the general characteristic is potted compounds to seal the opening. The potted compound usage is $1 \mathrm{imited}$ to areas of comparative low neutron flux. Resistance of these compounds to radioactivity should be investigated in order to be sure that their life will be satisfactory.

6.11.2 Trenches, Curbs and cells

Cell. Liners - The cells or areas that contain pipes are generajly encased in steel plate to prevent the reaction of liquid metals and concrete. The practice of lining cells varies over the world. In some places, they have elected to 1 ine only to the height of the largest spill and leave the rest of the concrete cell wall free. In most cases, they attempt to seal the concrete with a sealant that will keep the leakage down. In other places, they elect to 1 ine the cell in its entirety. The prastice is dictated by the concern for the cell integrity. Parlicularly is this true when you have an inert atmosphere in that: cell to prevent fire resulting from a pipe rupture. In all cases, the floors are sloped to allow direct flow of the liquid Inetal and to minimize available sodium surface area. This slope varies from $1 / 8$ to $1 / 4$ irches per foot $(10 \mathrm{~mm} / \mathrm{m}-20 \mathrm{~mm} / \mathrm{m})$ of 1 inear run. In every case the cell or compartment is leakcherked with appropriate pressures to determine its leak tightnes:; and to be sure it is within the specification established for the building. Usage has generally been with steel plate as opposed to sheet metal. The most used thickness being $1 / 4$ inch $(6.35 \mathrm{~mm})$. Users tend to use low alloy steels rather than stainless because of the cost.

Sum 2 - There is often an attempt to direct any spill into a sump or submerged container to further decrease the surface area available for burning. Obviously, the use of steel, and the diverting of liquid rnetal will utilize the cooling effect of the structural material. However, it should be remembered that large masses of sodiun or liquid metal are really tremendous sources of heat. Many of the experiments made wit. limited or small amounts of metal which have resulted in design recommendation in no way reflect the mass effect. Whenever the heat is present, concrete will give off water in sufficient quantities to promote burning of the 1 iquid metal. Witi hydrogen present, the explosive potential of the burning mass increases markedly. HEDL further showed in the spill of large quantity of material, burning will accelerate due to generation of water vapor from the concrete and its transport through vents even though the plate steel was in place. It is 
necessary, therefore, to make careful calculations for each system and assess the need for further separation of the sodium or ..iquid metal from the concrete. Use of insulating brick, or other materials, tends to lessen the effect of the large heat loacls on the concrete. It is suggested that alert designers considered each case in detail. References are included from whic:h further insight may be obtained.

Containment Pans - The design of containment pans has reached a higl degree of sophistication. The desire is to return spilled sodium to the cover of inert gas and to minimize the surface areia. The figures show several innovative ways that have been used successfully (see Eigures 60 through 66). Tests have shown significantly large amounts of sodium have remained unburned and firıs have been controlled rapidly. The German (GFK) design is an excellent example of the ric-rac cover for catch pans. These sys zems have provision for the introduction of inert gas under the covers.

The French direct the coolant away as rapidly as gravity will allow to a less surface active configuration. U.S. Praztice has been limited primarily to trenches and curbs to direct flow on a sloped floor and covered sumps. They use 1/4-inch-thick plates with one-inch punched holes to cover the trenches or sumps spaced at: about two per square foot.

\subsection{1 .3 Compartmentation}

Compartmentation of the reactor complex is governed in large measure by the constraints of the equipment and layout of the heat transfer system. Although all countries seem to practice compartmentation in the reactor nuclear island design, only the U.K. has made a statement as to possible guidelines for that compartmentation in a suggestion and rationale for sizing. It was suggested that $20,000 \mathrm{ft}^{3}$ is a reasonable maximum size to strive for. (58) This is based on the maximum size that can be quickly flooded with nitrogen and then cleared by a ventilation sysitem to remove the fume. This is essentialiy a $27^{\prime} \times 27^{\prime}$ $x: 27^{\prime}$ compartment. It seems like a reasonable standard to consider. Included in the figures are several examples of compartmentation in FFTF. In addition, an excellent example is seen from the SNR 300 reactor. These provide some idea of the lajout and configuration used in present LMFBR's.

\subsubsection{MISCELLANEOUS ITEMS}

Under this heading there are several items noted. These are personnel protective equipment, first aid for 1 iquid metal bu:ns, oxygen deficiency, handling, storage and disposal of sodium.

6..2.1 Sodium protective suit

since sodium and liquid metals burn through conventional 
protective garments and because there was no viable substitute materials, Division of Operational Safety, U.S. Department of Energy commissioned Hanford Engineering Development Laboratory (HEJL) to suggest a material and demonstrate its viability. Ovel the last several years, HEDL has accomplished that task and has had produced twenty suits for use at six DOE sites where sod $\therefore$ um or liquid metals are being used (see Figure 67).

The suit section consists of one-mil-thick annealed nickel foil to prevent the penetration of the liquid metal. In as much as the foil prevents passage of the liquid metal, it resillts in a molten sodium buildup on the surface which with the accompanying heat requires insulation to protect the wearer. Therefore, a layer of ceranic fiber insulation was added to the section. In order to keep the foil from being punctured or damaed during storage or in training, two layers of fiber glass cloth were placed in the outside of the protective section. On the inside of the section, a tightly woven material, essentially fire resistant, was employed to separate the wearer from the insulation.

The suit was designed for use only by professional fire people. This concept resulted because the suit utilizes a self-contained breathing device as a source of air allowing the user more complete mobility. The fire people are the only people that routinely use breathing equipment. Hence when you add 30 lbs $(13.6 \mathrm{~kg})$ of extra protective gear making up the suit to the $301 \mathrm{bs}(13.6 \mathrm{~kg})$ wejght of the breathing system, you have a total of 60 lbs $(27 \mathrm{~kg})$ of protective equipment. In order to be effective, only a professional fire fighter in good physical condition can really use this. Furthermore, the suit was designed for two minute use either to rescue personnel or to shutdown an operating system. The suit was constructed to prevent temperatures within the suit rising above $170^{\circ} \mathrm{F}\left(77^{\circ} \mathrm{C}\right)$. That temperature respresents the point at which blistering occurs on human skin.

The suit was tested in a $12 " \times 12^{\prime \prime}(30.5 \times 30.5 \mathrm{~cm})$ section first, then in full scale with an instrumented manikin. The suit was subjected to $1000^{\circ} \mathrm{F}\left(538^{\circ} \mathrm{C}\right)$ sodium sprayed under 50 psig $\left(35,150 \mathrm{~kg} / \mathrm{m}^{2}\right)$ at a distance of 15 inches $(38 \mathrm{~cm})$. It was successfully tested many times and repeatedly demonstrated its ability to resist the sprayed molten sodium environment. It has not been demonstrated with a person in it, but there is no reason to believe that it would not afford the desired protection. Like all pieces of protective gear, it needs to be cared for and cleaned after use. If sodium remains on the suit surface, it tends to absorb moisture from the air to form sodium hydroxide. When this is left on the fiber glass, embrittlement results and the outer layer of fiber glass will crack. It has been demonstrated that the outer layer deterioration does not affect the under layer. Likewise, it has been determined that a patch can easily be placed on the cracked fiberglass and riveted into place with blind rivets. 
The original suit was fabricated as a maxi-coat covering the fireperson from head to toe. A second version, suggested by the experienced fire people and meeting their need for greater movioment and flexibility has resulted in horizontally split suit type with separate pants and torso section. In both cases the hear piece is removable and is donned after the self-contained breathing device has been placed in service.

The suit can become very hot inside from body heat and insulation. The suit manufacturer has a state-of-the-art personnel cooling system for the torso area that can be added at a very nominal cost. This would make the wearing of the suit considerably more comfortable. It weighs about five pounds.

The suit was designed and tested with sodium at $1000^{\circ} \mathrm{F}$ $\left(538^{\circ} \mathrm{C}\right)$ and sprayed under 50 psig argon pressure through an oriEice located 15 inches $(38 \mathrm{~cm})$ from the suit. This resulted in $a$ nine inch diameter circle of sprayed sodium and discharged abolt $1 / 2 \mathrm{lb}(0.2 \mathrm{~kg})$ per spray application. The suit has not been tested for any other liquid metal. There are plans to che ak the suit with lithium. At this time, there is little to suggest that 1 ithium would cause any problems in reacting with the fiberglass any more than the sodium. HEDL will be conducting these tests in 1978-1979.

There is interest in applying the suit to other environments. The sodium suit was tested in steam to see its resistance to high pressure and temperature. The steam conditions wer $2465^{\circ} \mathrm{F}\left(241^{\circ} \mathrm{C}\right)$ and $465 \mathrm{psig}\left(326,895 \mathrm{~kg} / \mathrm{m}^{2}\right)$ at a distance of 12 inches $(30.5 \mathrm{~cm})$ with a one-half inch diameter pipe nipple directed normal to the surface. The section showed the impact of the steam, but did not deteriorate in any way. The vendor for the suit is projecting some additional tests at higher pressures and temperatures with the thought in mind for use in the inspection of steam plants and in other hazardous environments.

\subsection{2 .2 General Protective Gear for Sodium Handling (4)}

Because of the hazards of high temperature material handling, it is recommended that persons handing liquid metals wear clothing that will resist the 1 iquid metals. As was discussed on the suit, most materials will burn through when sodium or 1 iquid metals contact them. However, for lighter duty and as a first 1 ine of protection, flame resistent clothes are recommended (see Figures 68 and 69). In addition, 1 ong gauntlet gloves of either polyvinyl chloride or chrome leather are suggested. Eye protection is a must, with both chemical goggles (fitting tightly over the eyes) and a face shield (attached to a hardhat) are recommended. It is advisable to wear leather shoes with safety toes also. This outfit is the minimum protection recommended to personnel handling 1 iquid metals. 
6.12 .3 First Aid for Liquid Metal Burns (4)

This is a subject that may seem out of place in the discoussion of liquid metal fire control engineering, but wherever 1 iquid metals are used it is well to be sure that all necessary information is available for safe handling and use. we therefore include a section on first aid.

It is assumed that people handling liquid metals will routinely protect their eyes. If eyes are splashed, it is too late to recover. It might be noted that with the rather common use of contact lens, people handling liquid metals should not use them. Experience has shown that when liquid metal smoke or fume is present, it especially irritates the eyes under the lens and this condition often results in problems (see Figure 70 ).

Basic first aid instructions are (1) to brush away or remive the liquid metal trat splashes on you or another person as quickly as possible, (2) remove the clothes and get under a safety shower or hose. The water bath (shower, hose) should last for 5 to 10 minutes minimum in order to irrigate the areas contacted by liquid metal, (3) after showering, no oily agents (e.y., unguents, salves, or sprays) should be put on the burned areas. If required, cover very loosely with a sterile bandage, (4) take the patient quickly to a physician for extended treatment. The physician will normally neutralize the area and treat as a burn. The biggest dangers are infection and shock. Time is of the essence in the treatment.

6.12 .4 Oxygen Deficient Atmospheres (57)

This subject has been mentioned several times during the discussion of inert gases and their use. It is a very serious prcblern in the use of 1 iquid metal because of the need for inert atmospheres. Its presence can result in marked decreases in the oxygen content of the air and is lethal. In 1978, there have been a rash of oxygen deficient incidents resulting in death in all industries. Lives have been needlessly taken because of lack of awareness as well as a result of reacting improperly to situations. For more information, a training program produced for the Division of operational and Environmental Safety, U.S. Department of Energy, is recommended for use.(60)

\subsubsection{Handling and storage of Sodium}

Sodium for large systems is ordered and delivered in taik car lots. The cars are a special design, meeting U.S. De partment of Transportation specifications for hazardous malierials. The designation is $105 \mathrm{~A} 300 \mathrm{~W}$ which is certified for transport of sodium or liquid metals (see Figure 7l). It is characterized by heating coils using hot oil (for melting contents), covered and protected openings, to receive inert gas and the liquid metal loading. The liquid metal valves have a 
dip pipe eductor leg that extends down to within 4 inches (10 $\mathrm{cm}$ ) of the tank bottom. It is customary to drain only $95 \%$ of the material in the tank car, because particulate materials, such as calcium, tend to concentrate in the tank bottom and hence are prevented from going into the liquid metal system. After discharge, the remaining liquid metal in the tank is remcived at a railroad shop cleaning station and the car returned for reuse. The cars hold about 10,000 gallons $\left(3.8 \times 10^{4} 1\right)$ $(-81), 0001 \mathrm{bs})\left(3.6 \times 10^{4} \mathrm{~kg}\right)$ of material. The material is plac:ed in the cars in the 1 iquid condition under an inert gas at abo tt $300^{\circ}$ to $350^{\circ} \mathrm{F}\left(150-175^{\circ} \mathrm{C}\right)$. The contents of the car are allowed to cool under inerted conditions. After cooling the inel:t gas is recharged to bring the pressure of the car to about $10 \mathrm{psig}\left(7 \times 10^{3} \mathrm{~kg} / \mathrm{m}^{2}\right)$ and the car is resealed and shipped.

Precautions in the use of tank cars relates mostly to the handling at the plant (see Figure 72). A hot oil melt station is required to pump the oil through the built-in tank coils. This brings the tank car to the 1 iquid metal melting point plus Eron $50^{\circ} \mathrm{F}\left(10^{\circ} \mathrm{C}\right)$ to $100^{\circ} \mathrm{F}\left(38^{\circ} \mathrm{C}\right)$ higher to allow the contents to be pumped out. Removal of the 1 iquid metal or pumping is by pressure differential. A pressure difference of about 5 $\left(1.75 \times 10^{3} \mathrm{~kg} / \mathrm{m}^{2}\right)$ to $10 \mathrm{psig}\left(7 \times 10^{3} \mathrm{~kg} / \mathrm{m}^{2}\right)$ of inert $\mathrm{gas}$ is used. The hazarcous operations occur when improper connections are made to the receiving tank and in making and breaking connections to the tank car. Generally sampling is required of the tank contents, and a filter is placed in line to keep any particulates from passing from the tank car to the receiving system. The filter is often a stainless steel frit and will remove anything greater than 20 microns in size. The filters are generally in tandem in the pipe stream so that as the one clcgs from use, it can be by-passed without system shutdown and maintenance operations conducted.

The smaller quantities of sodium and liquid metals are supplied in inerted drums either of the standard 55 gallon (2(i8 liter) size or 35 gallon (133 liter) size (see Figure 73). These are also built to Department of Transportation (DOT) standards for transport of liquid metal (sodium) as a hazardous material. They have special formed seams with seals and are leak checked before use. Removal of the material from the ba:-rels is made possible by a handling rig, shown in the figure. The barrel is warmed by a heater and the liquid metal is removed by inert gas pressurization. The amount of liquid me:al removed is measured by difference with a weighing device.

Storage of 1 iquid metal materials must be in locations where they will not encounter water. Sheds, buildings, or enslosures should be metal with no sprinkling systems. In the event of barrel rupture, the water would not be present to react. In the solid condition, without water, liquid metals will oxidize, but present 1 ittle hazard. Water will cause the production of hydrogen gas and heat and can result in fire and violent splattering. 
Tank cars containing liquid metal should be stored in areas where nothing can ram or harm them and in areas which can be loclied. Proper labels and periodic monitoring will help in keeping them from harm. Much sodium has been handled safely over the years because of its extensive use in manufacture of autcmotive fuels. It has minimum hazard in comparison with many other materials of commerce.

\section{1:.6 Disposal of Liquid Metals (Sodium) (Figure 74)}

A word should be included on the matter of disposal of non-radioactive fire wastes generated by emergency conditions. Was:es have traditionally been dumped in cans and then placed in pools of water. If the cans do not begin reaction right away, puncture of the cans by $r$ ifle shot has often been resorted to. With the advent of environmental restraints on burning, prozesses such as controlled burning and scrubbing of the fume are often used. This requires the installation of a burning chamber and an appropriate scrubber installation that will limit release to the air. Burning in this manner is still the most common way of disposal.

There are a number of specialized processes(35) for NAK and sodium which inject the molten sodium into water thus corverting it to hydroxide solution and free hydrogen. The volume of water in which the liquid metal is injected is large with respect to the liquid metal hence the water acts as a heat sink and also keeps the overall concentration of hydroxide at a mariageable level. The water can then be neutralized at the corvenience of the operator.

When large spills occur, if the fire control is very good, only about 10 to $15 \%$ of the liquid metal actually burns. Thus the: residue left is a small amount of oxide and a large amount of unburned metal. This material is removed in the solidified state after flooding the surface with mineral oil. Jackhammers are then used to spade up chunks about six inches to a side or about $5 \mathrm{lbs}(2.3 \mathrm{~kg})$. These are sealed in $55 \mathrm{gal}(208$ 1) drums fol: storage. Occasionally, a sprinkling of calcium carbonate is us 2 in the drums to decrease the possibility of fire. The solium is then burned at the convenience of the operational scinedule.

It should be noted that fire extinguishing agents will often be mixed with sodium residues. This renders the solid mass unusable. It will have to be stored for disposal in a rezeptacle. Controlled burning is again the most usual way of handling disposal. A caution should be added on the stirring of liquid metal sludges that have been in storage for some time. The best bet is to dispose of residues as soon as practical to prevent complications.

NAK requires greater care in disposal than does sodium. This is true for two reasons: First, NAK is 1 iquid at room 
temperature and hence tends to be less easy to handle for that reason; the second reason is the greater possibility for buildup of superoxides. The superoxides can be set off with only a touch or jar and sometimes cause violent explosions. While the circumstances must be just right for the production of the superoxides, there is always the concern that they are present. The rule of thumb seems to be the longer NAK has been in storage and open in any way to the oxygen in the air, the greater is the chance that it contains the dangerous oxides. Potassium superoxide can easily form in 2-15 minutes following Nak ignition. The superoxide explosion potential in liquid metals is also dependent upon organic contamination when used in small quartities. Since NAK or potassium and kerosene tend to form a binary explosive system if any superoxides are present, organics should seldom be used with alkali metals. Disposal is therefore complicated by this concern. Reaction of fresh NAK with kerosene is one way to dispose of small quantities. A second way is use of controlled water vapor nitrogen mixture, well agilated, to react the total volume inside a reaction chamber. In the case of EBRI, large quantities of NAK were reacted much the same way as sodium. An underwater injection of the hot molzen metal was made into water of sufficient volume and depth to absorb the heat generated.

The above remarks relate to non-radioactive residues. In the handing for disposal of radioactive residues, many of the above systerns could be used for small quantities, provided the processes were confined to hot cells or controlled release facilities. For the most part, radioactive materials are stored in drums for burial because few if any facilities for handing the disposal of large quantities of liquid metals exist. 


\section{TYPES OF SODIUM LEAK DETECTORS}

\begin{tabular}{|c|c|c|c|}
\hline DETECTED & TYPE DETECTOR & SENSITIVITY & COMMENTS \\
\hline \multirow[t]{2}{*}{$\begin{array}{l}\text { LIQUID } \\
\text { SODIUM }\end{array}$} & $\begin{array}{l}\text { PAIR OF ELECTRODES } \\
\text { (i.e. "SPARK PLUG") }\end{array}$ & $\begin{array}{l}\text { LMEC TESTS SHOWED } \\
\text { SENSITIVITY } \\
\text { @1 } 160 \mathrm{~g} / \mathrm{hr}\end{array}$ & $\begin{array}{l}\text { WIDELY USED IN USA } \\
\text { AND IN EUROPE. PLANNED } \\
\text { FOR FFTF PRIMARY SYSTEM }\end{array}$ \\
\hline & $\begin{array}{l}\text { PAIR OF WIRES SERVING } \\
\text { AS ELECTRODES }\end{array}$ & $\begin{array}{l}\text { COMPARABLE TO } \\
\text { SPARKPLUG }\end{array}$ & $\begin{array}{l}\text { USED BY DUTCH AND FRENCH } \\
\text { RELIABLE DESIGN CONFIGURA- } \\
\text { TION NOT AVAIABLE FOR FFTF }\end{array}$ \\
\hline $\begin{array}{l}\text { SODIUM } \\
\text { VAPOR }\end{array}$ & $\begin{array}{l}\text { ABSORPTION OF SPECIFIC } \\
\text { FREQUENCIES OF LIGHT }\end{array}$ & $\begin{array}{l}75 \times 10^{-6} \mathrm{~g} / \mathrm{m}^{3} \\
\text { UNDER BENCH TEST } \\
\text { CONDITIONS }\end{array}$ & $\begin{array}{l}\text { LMEC TESTS NOT SUCCESSFUL } \\
\text { UNABLE TO MAINTAIN SODIUM } \\
\text { IN VAPOR PHASE LONG ENOUGH } \\
\text { FOR DETECTION }\end{array}$ \\
\hline \multirow{4}{*}{$\begin{array}{l}\text { (EMITTED } \\
\text { FROM NON- } \\
\text { FLOWING } \\
\text { LEAKS) }\end{array}$} & FLAME PHOTOMETRY & $1 \mathrm{ppb}$ & $\begin{array}{l}\text { REQUIRES PIPING } \\
\text { OF SAMPLES TO CHEMICAL } \\
\text { ANALYSIS ROOM }\end{array}$ \\
\hline & \multicolumn{2}{|c|}{$\begin{array}{l}\text { CHEMICAL METHOD (COLOR } 2.3 \times 10^{-4} \mathrm{~g} / \mathrm{m}^{3} \\
\text { INDICATION PHENOLPHTHALEIN } \\
\text { OR THYMOL BLUE) }\end{array}$} & $\begin{array}{l}\text { FINAL ANALYSIS PERFORMED IN } \\
\text { LABORATORY }\end{array}$ \\
\hline & pH METHOD & $1 \mathrm{ppb}$ & $\begin{array}{l}\text { SUCCESSFUL LMEC TESTS: } \\
\text { COMMERCIAL PH METERS AVAIL- } \\
\text { ABLE-METHOD SUITABLE FOR } \\
\text { ON-LINE USE }\end{array}$ \\
\hline & CONDUCTIVITY METHOL) & $1 \mathrm{ppb}$ & $\begin{array}{l}\text { COMMERCIAL METERS AVAILABLE. } \\
\text { METHOD SUITABLE FOR ON- } \\
\text { LINE USE }\end{array}$ \\
\hline \multirow{2}{*}{$\begin{array}{l}\text { SODIUM } \\
\text { VAPOR. } \\
\text { SODIUM } \\
\text { OXIDE } \\
\text { MIXTURE }\end{array}$} & $\begin{array}{l}\text { PLUGGING TYPE } \\
\text { FLOWMETER }\end{array}$ & $\begin{array}{l}\text { "AS RESPONSIVE } \\
\text { AS ANY METER" }\end{array}$ & $\begin{array}{l}\text { LMEC SUCCESSFULLY TESTED. } \\
\text { SENSITIVE TO FALSE ALARMS }\end{array}$ \\
\hline & $\begin{array}{l}\text { FILTER TYPE } \\
\text { FLOWMETER }\end{array}$ & $\begin{array}{l}\text { PROBABLY BETTER } \\
\text { THAN PLUGGING } \\
\text { TYPE }\end{array}$ & $\begin{array}{l}\text { NO TEST DATA. SENSITIVE } \\
\text { TO FALSE ALARMS }\end{array}$ \\
\hline $\begin{array}{l}\text { RADIATION } \\
\text { FROM } \\
\text { AIRBORNE } \\
\text { PARTICULATE }\end{array}$ & $\begin{array}{l}\text { FILTER FOLLOWED BY } \\
\text { GAMMA MONITOR } \\
\text { S }\end{array}$ & $\mu \stackrel{8 \times 10^{-10}}{\mu \mathrm{Ci} / \mathrm{cc}}$ & $\begin{array}{l}\text { COMMONLY USED FOR PRIMARY } \\
\text { LOOP OF NUCLEAR REACTORS }\end{array}$ \\
\hline $\begin{array}{l}\text { SMOKE } \\
\text { DETECTION } \\
\text { SODIUM } \\
\text { OXIDE }\end{array}$ & $\begin{array}{l}\text { VARIOUS METHODS } \\
\text { (IONIZATION } \\
\text { PHOTO ELECTRIC } \\
\text { LASER BEAM) }\end{array}$ & $\begin{array}{l}\text { VARIABLE : LIMIT } \\
1.5 \times 10^{-3} \mathrm{~g} / \mathrm{l}\end{array}$ & $\begin{array}{l}\text { METHODS HAVE BEEN APPLIED } \\
\text { IN SODIUM SYSTEMS }\end{array}$ \\
\hline $\begin{array}{l}\text { HYDROGEN } \\
\text { (FROM Na } \\
\text { REACTION } \\
\text { WITH H2O) }\end{array}$ & HYDROGEN DETECTOR & ABOVE $1.5 \mathrm{~g} / \mathrm{hr}$ & $\begin{array}{l}\text { LMEC TESTED SUCCESSFULLY } \\
\text { BUT APPEARS NOT SUITABLE } \\
\text { IF TRITIUM IS PRESENT }\end{array}$ \\
\hline
\end{tabular}

REFERENCE 49 


\section{LEAK DETECTORS}
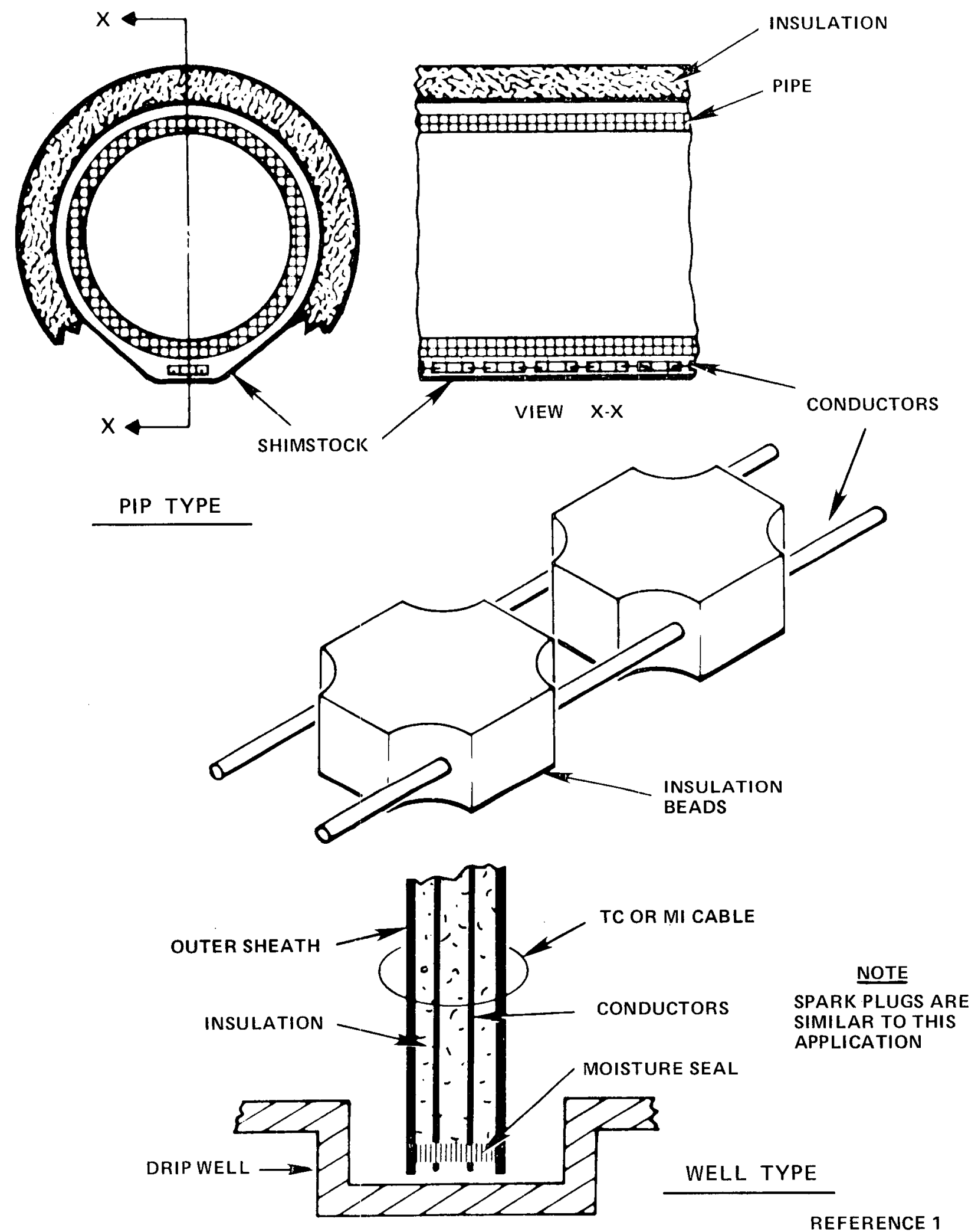

REFERENCE 1 


\section{TYPE OF BEADS DETECTORS USE}
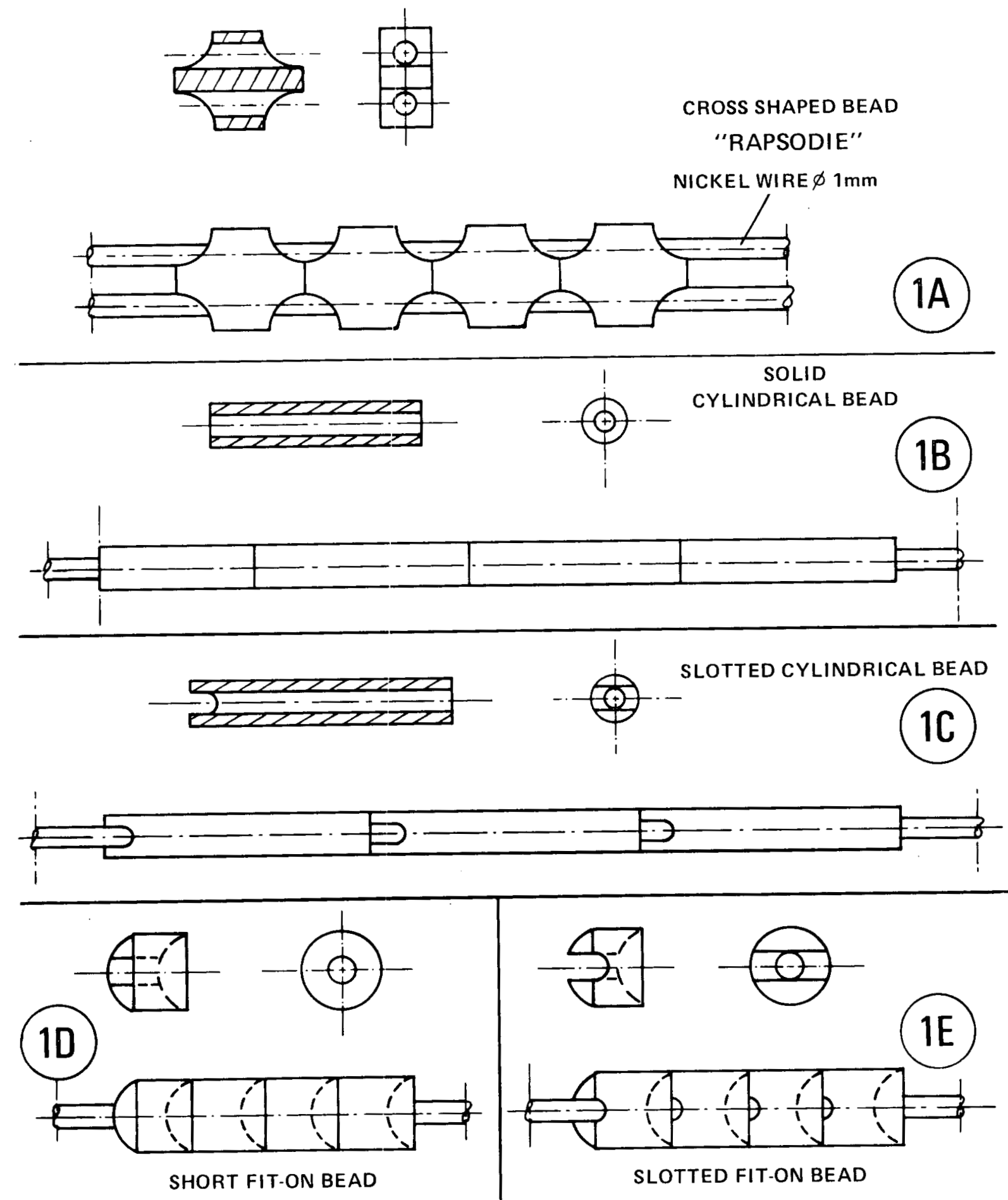

SHORT FIT-ON BEAD 


\section{CONTAINMENT PENETRATIONS}

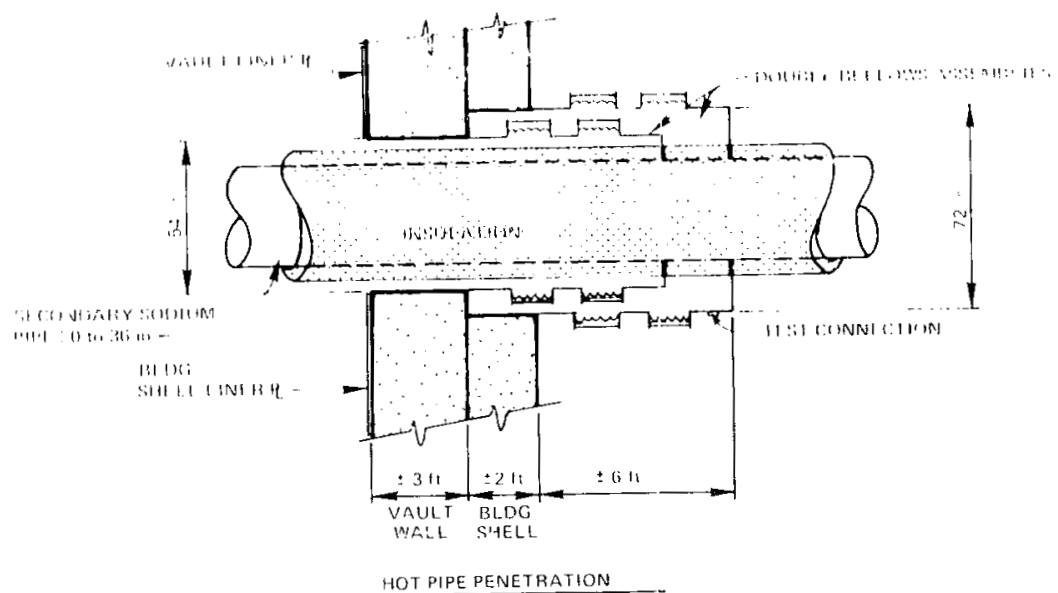

$\frac{\text { HOT PIPE PENETRATION }}{\text { ITYPICAL SECONDARY SODIUVI) }}$
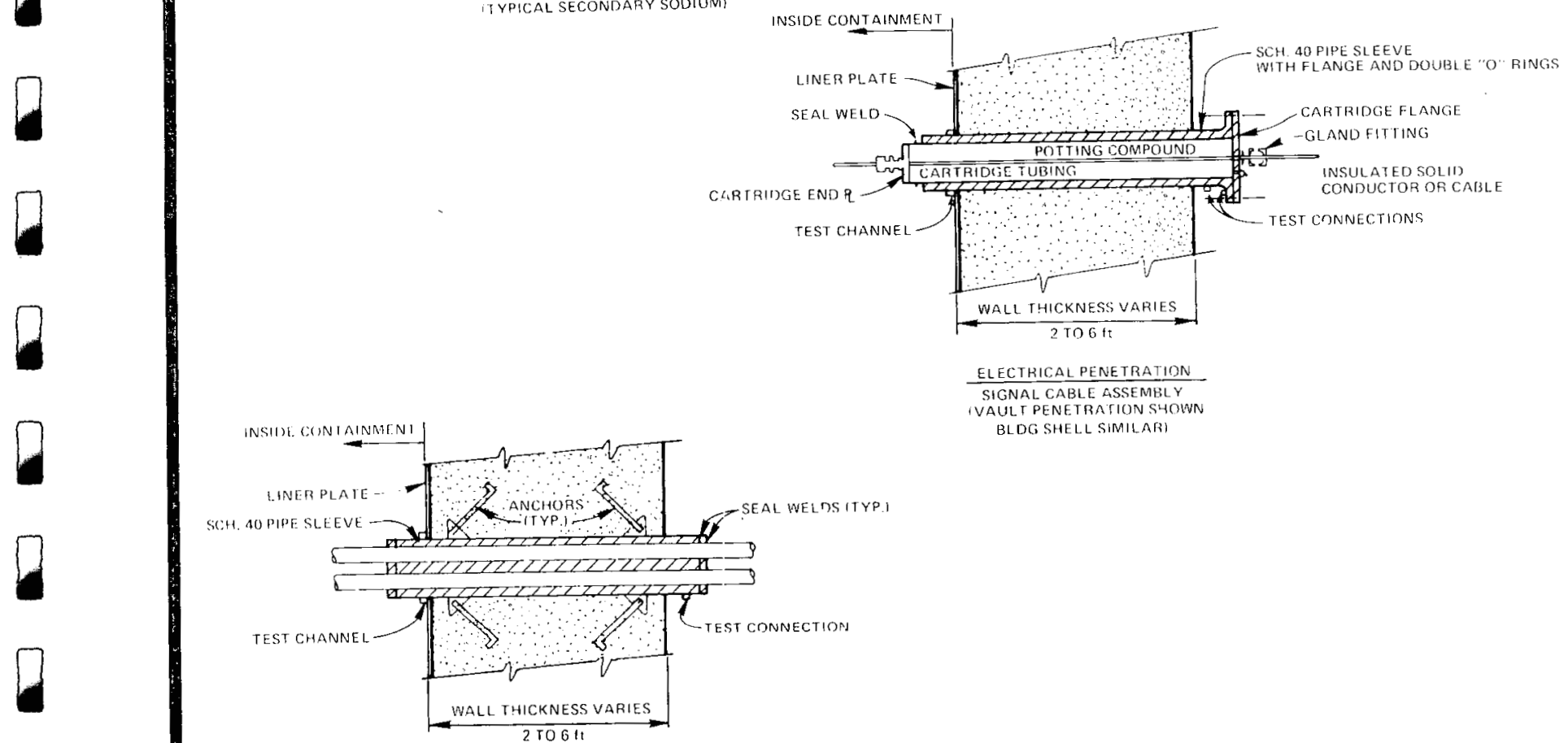

TEST CHANNEL

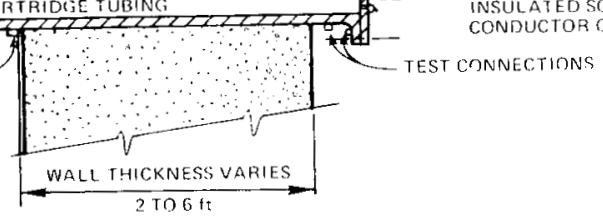

ELECTRICAL PENETRATION

SIGNAL CABLE ASSEMELY

BLDG SHELL SIMILARI

COLD PIPE PENETRATION

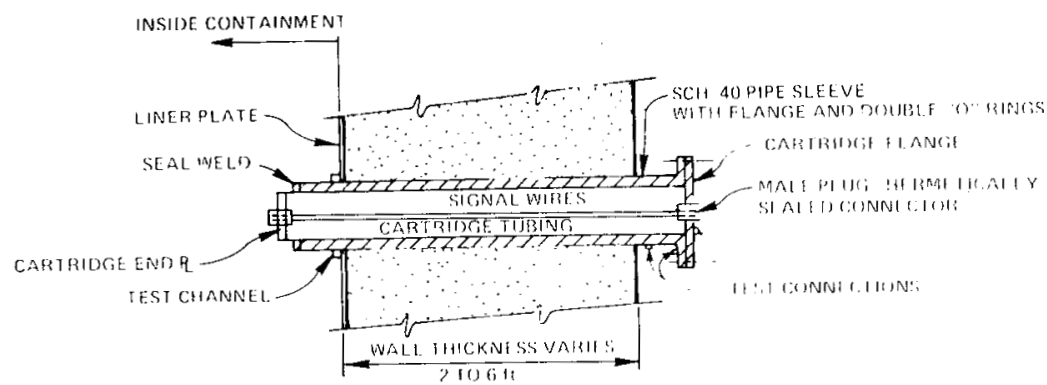

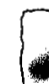

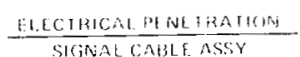

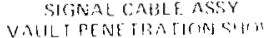

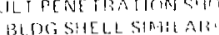

REFERENCE 1

FIGURE 59 


\section{U.S. TRENCH DETAIL}
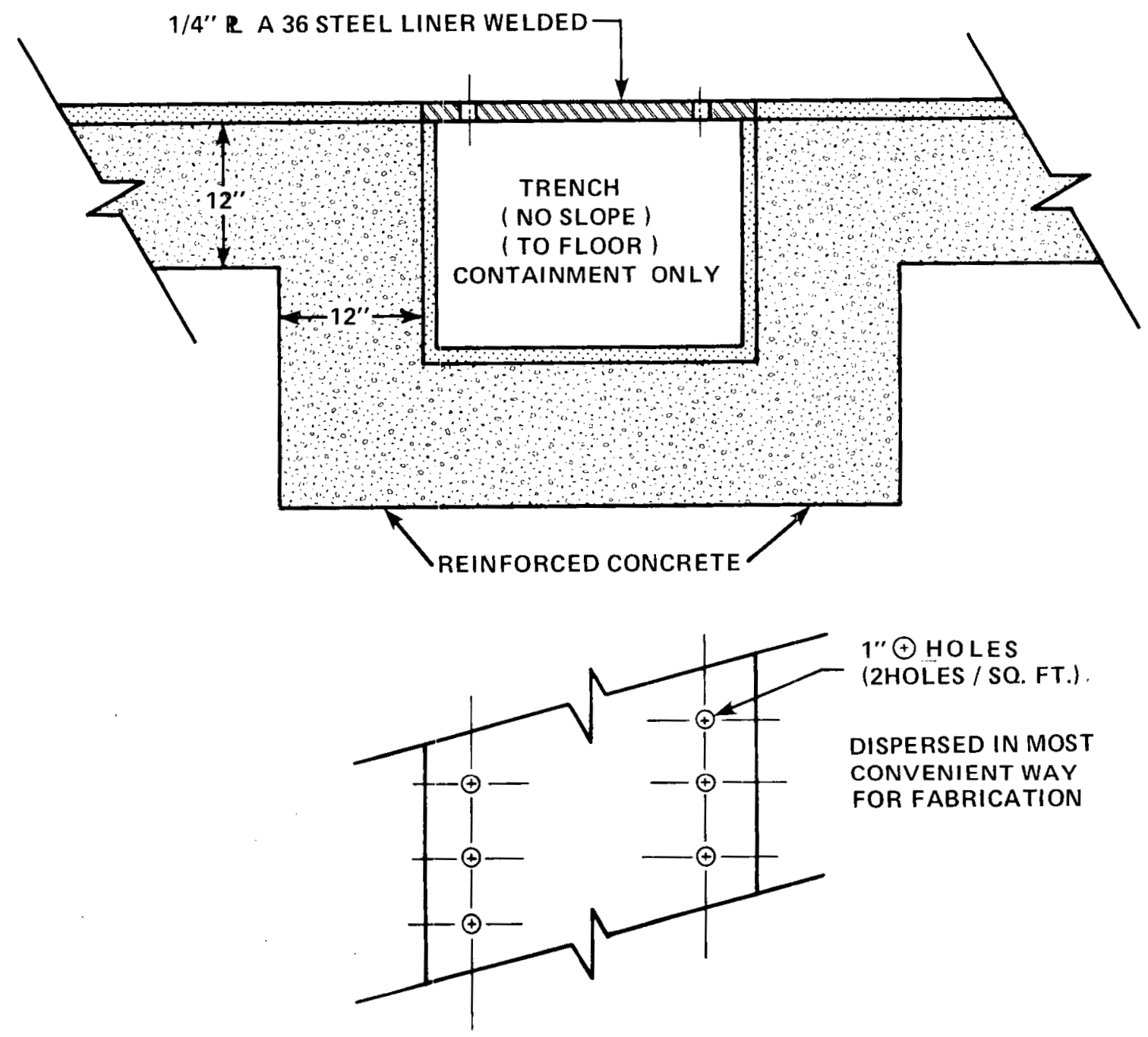

NOTE: DEPTH \& WIDTH OF TRENCH ARE AS REQUIRED

REFERENCE 15

FIGURE 60 


\section{GERMAN (GFK) RIC-RAK PLATE}

CATCH PAN FOR SODIUM

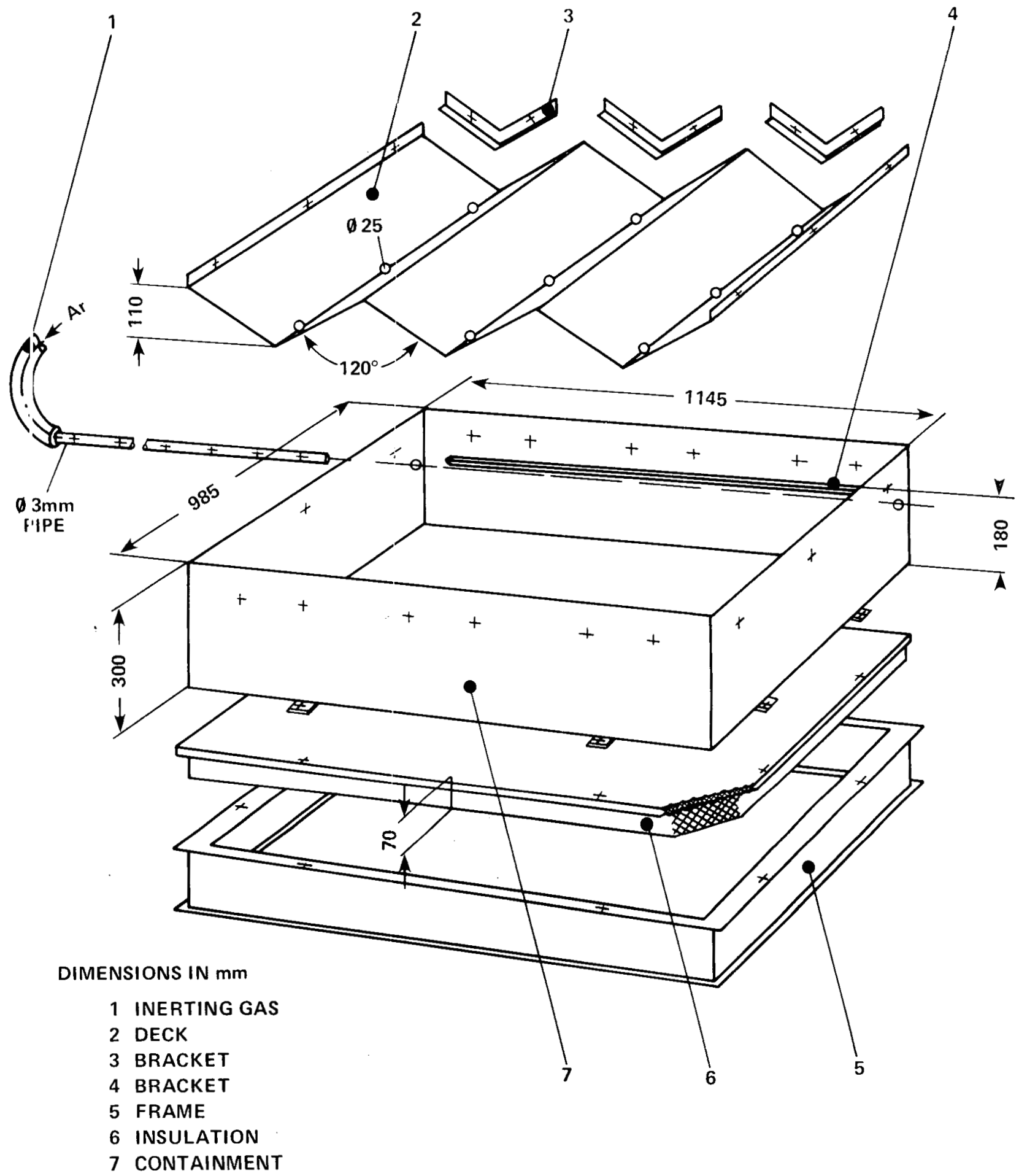

REFERENCE 27

FIGURE 61 
GERMAN (GFK) RIC-RAK PLATE $4.5 \mathrm{~m}^{2}$ CONTAINMENT

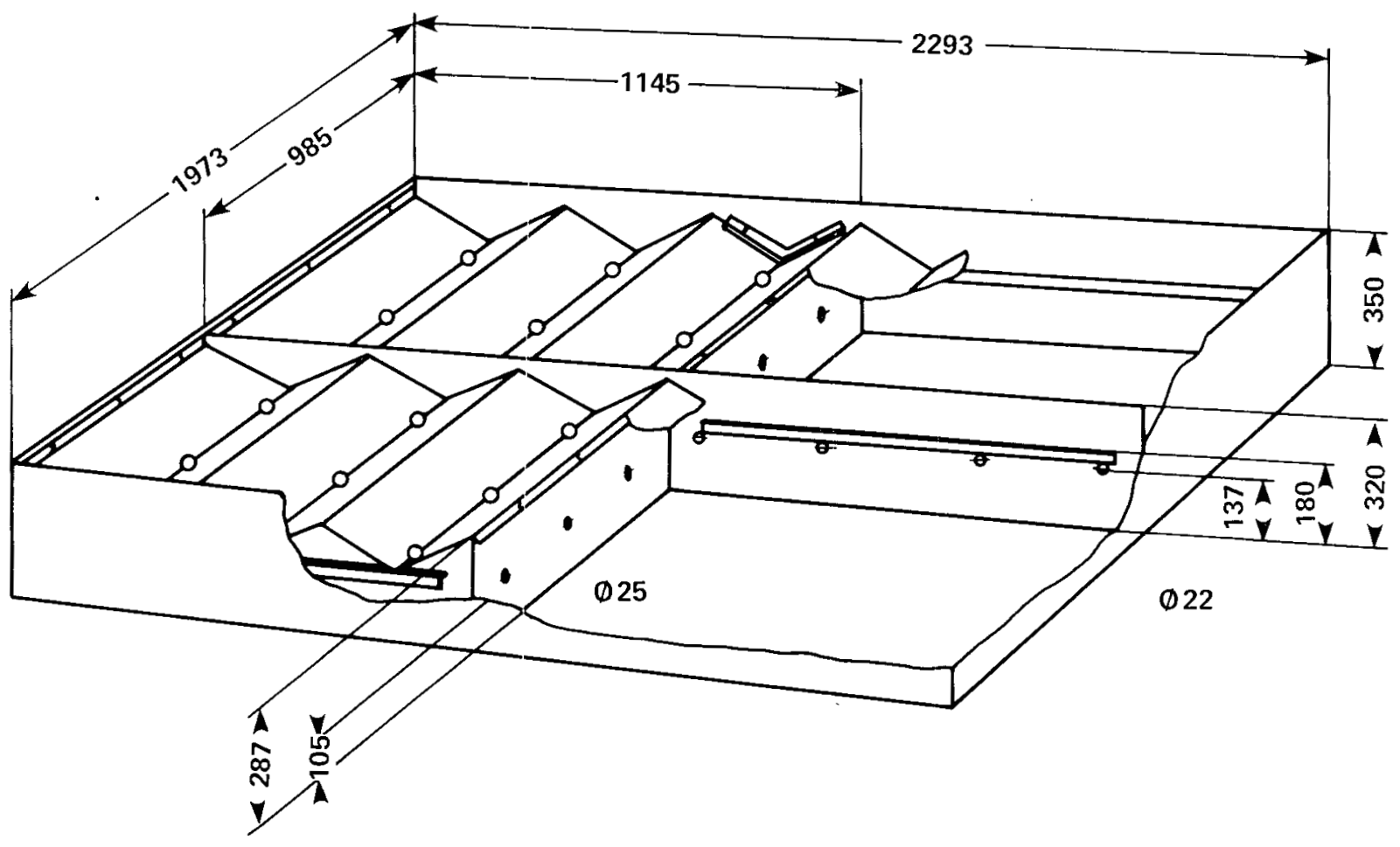

REFERENCE 27

FIGURE 62 


\section{GERMAN (GFK) RIC-RAK PLATE $100 \mathrm{~m}^{2}$ SODIUM CONTAINMENT}
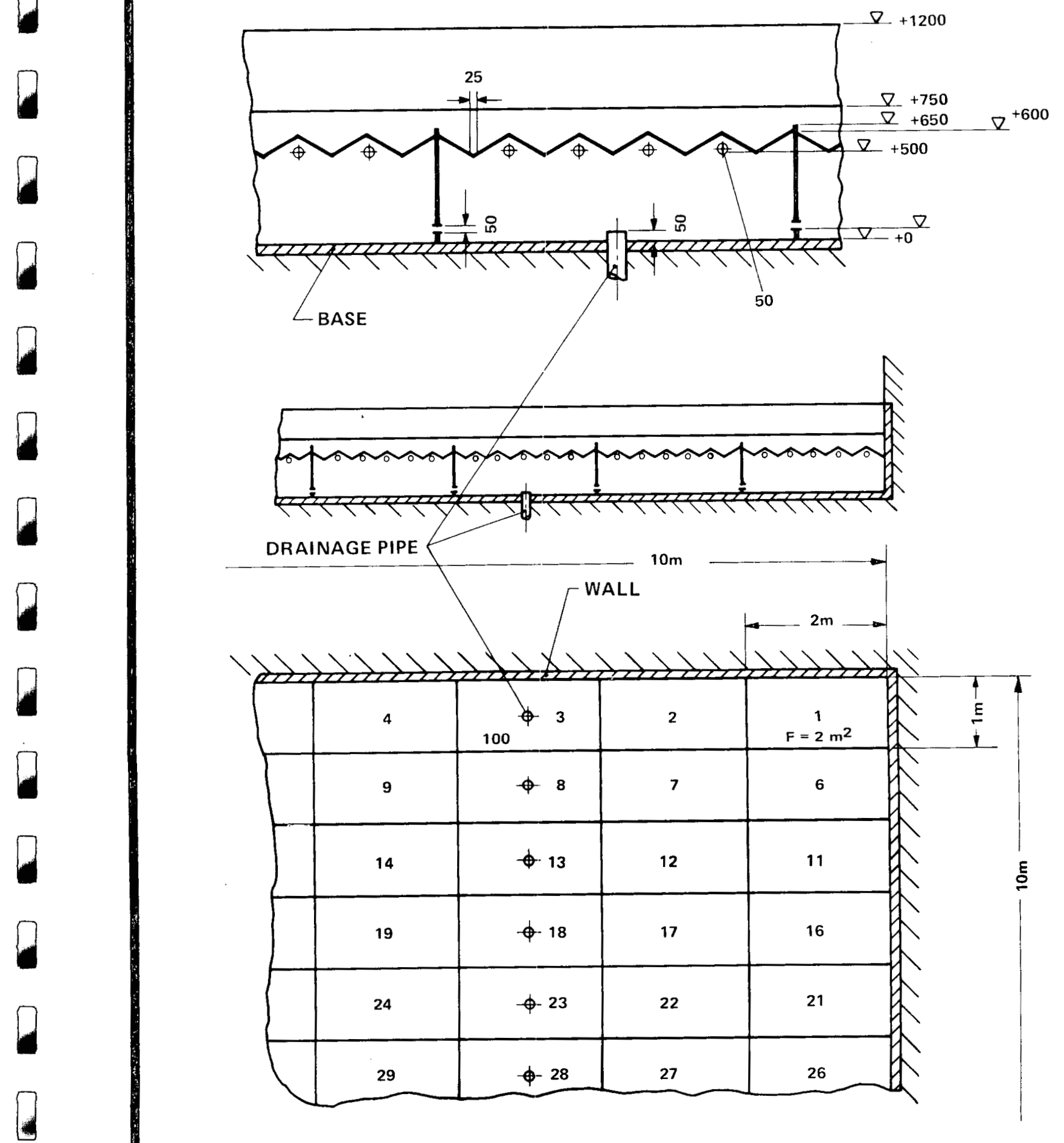

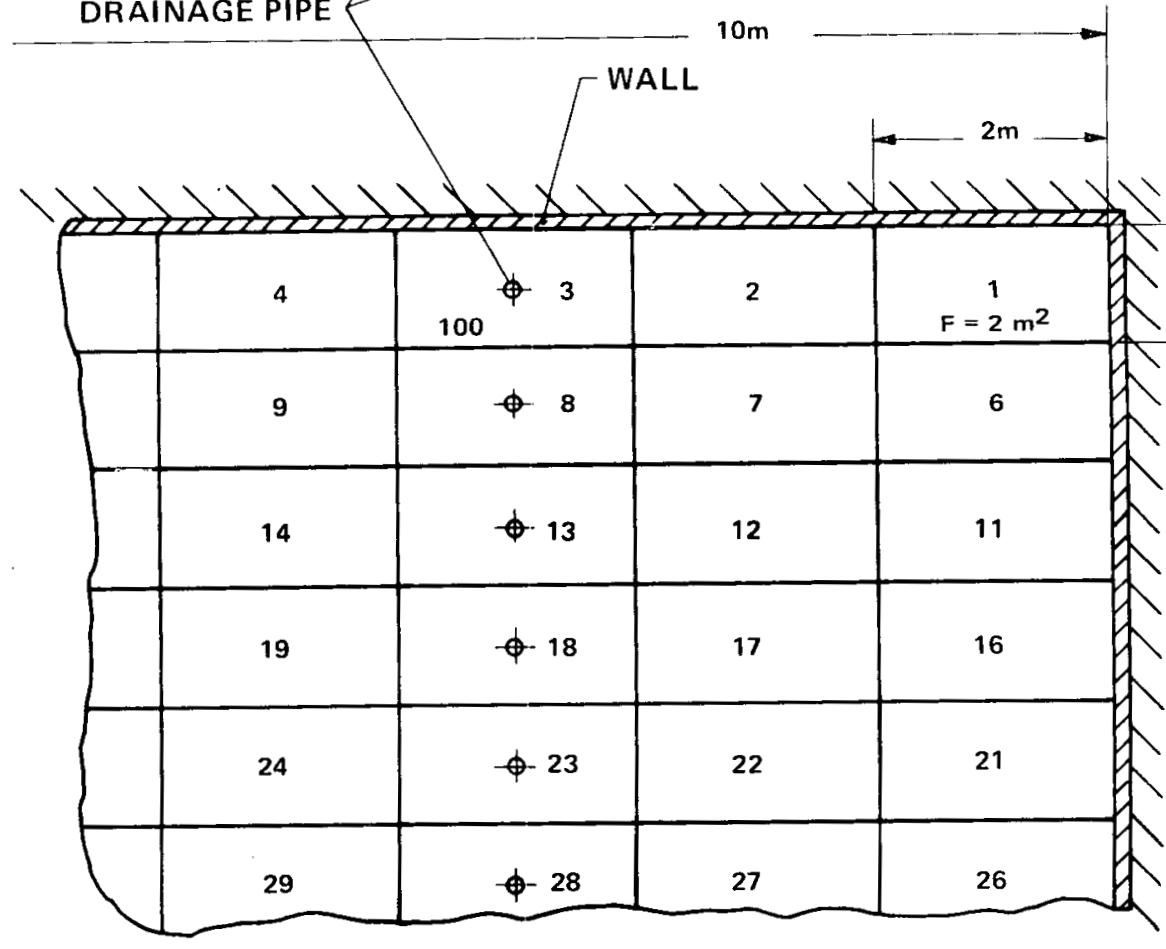

FIGURE 63 


\section{FRENCH SODIUM CONTAINMENT CATCH PAN SYSTEM}
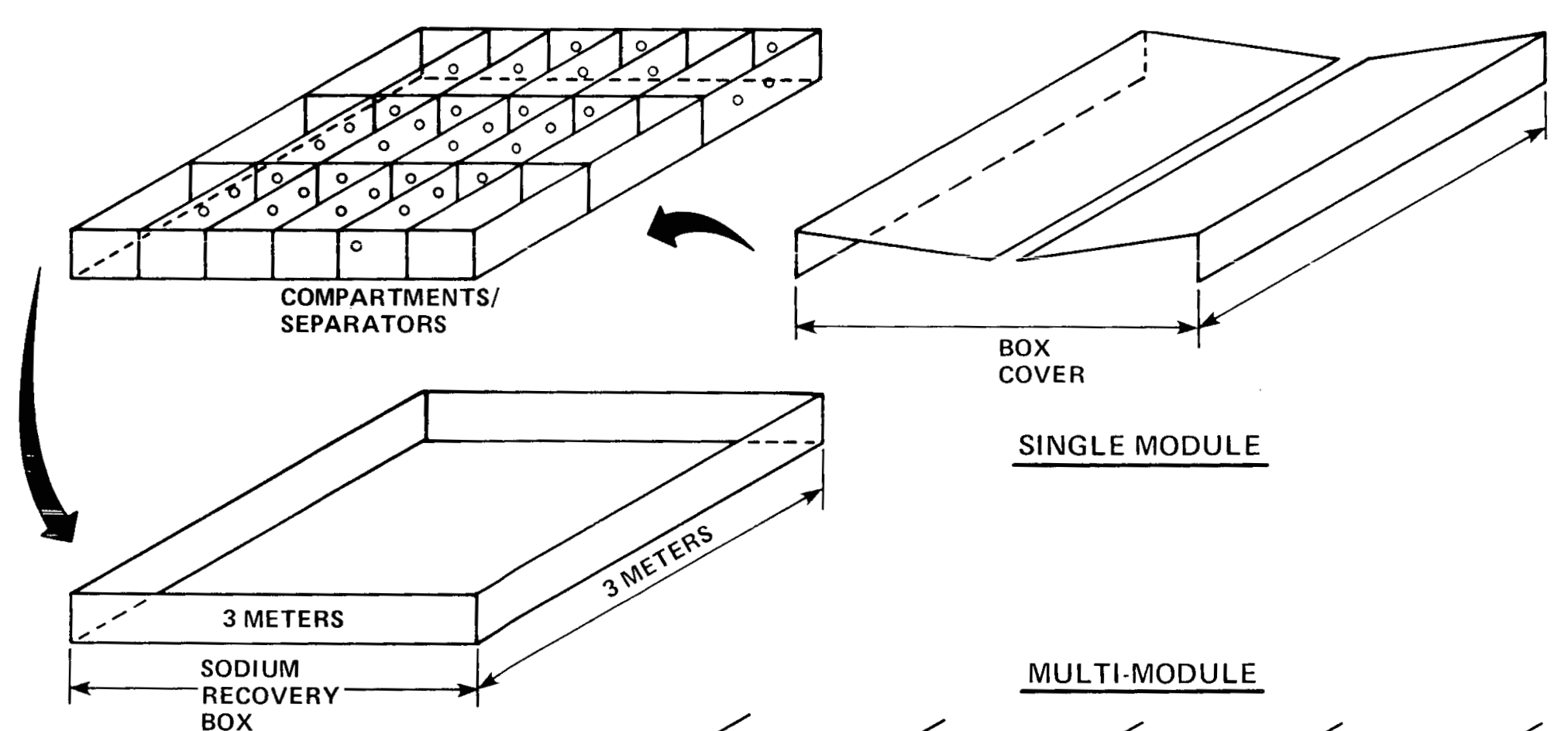

SINGLE MODULE

REFERENCE 25

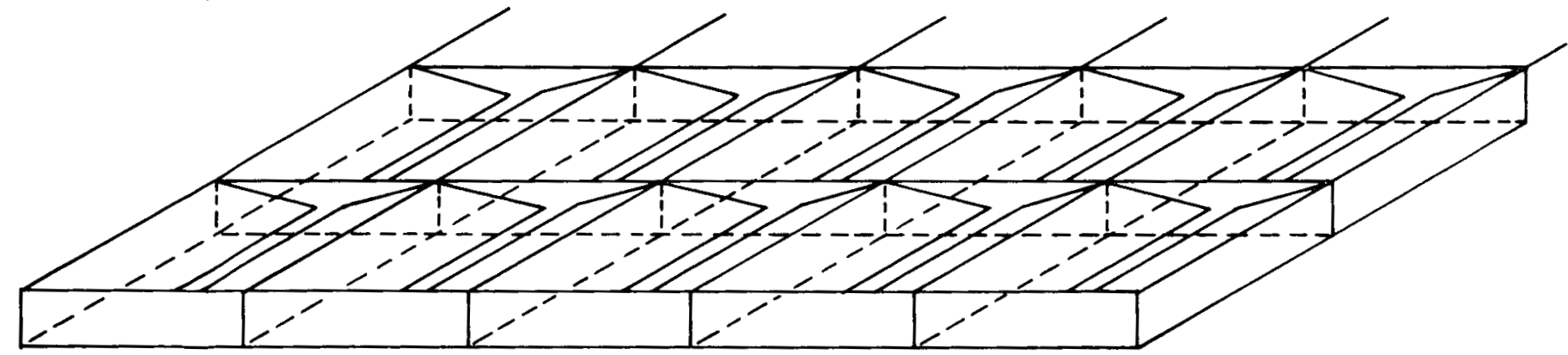




\section{CATCH TRAY ARRANGEMENT TO EXTINGUISH SODIUM FIRES, UKAEA}

( PROPOSED FOR PFR)
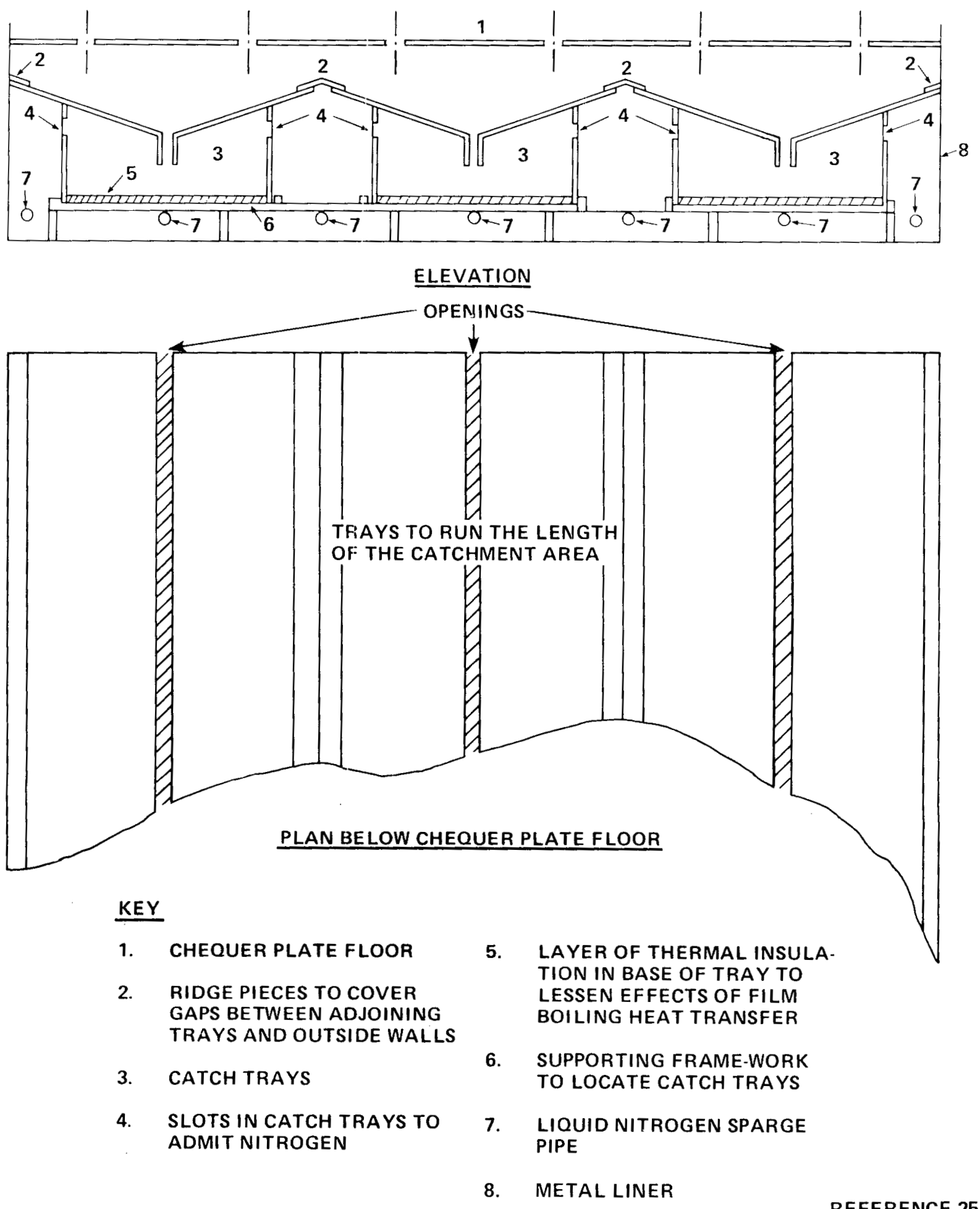

ALL METAL WORK IN CATCH TRAY AREA TO BE STAINLESS STEEL 


\section{PROTECTIVE CLOTHING}

- flame RETARDANT COVERALLSNO POCKETS OR CUFFS

- hARD hat - PHENOLIC RESIN - FULL BRIM FACE SHIELD AND CHEMICAL GOGGLES

- GLOVES - LEATHER OR PVC LONG GAUNTLET

- LEGgINGS - CHROME LEATHER

- LeATHER ShOES 


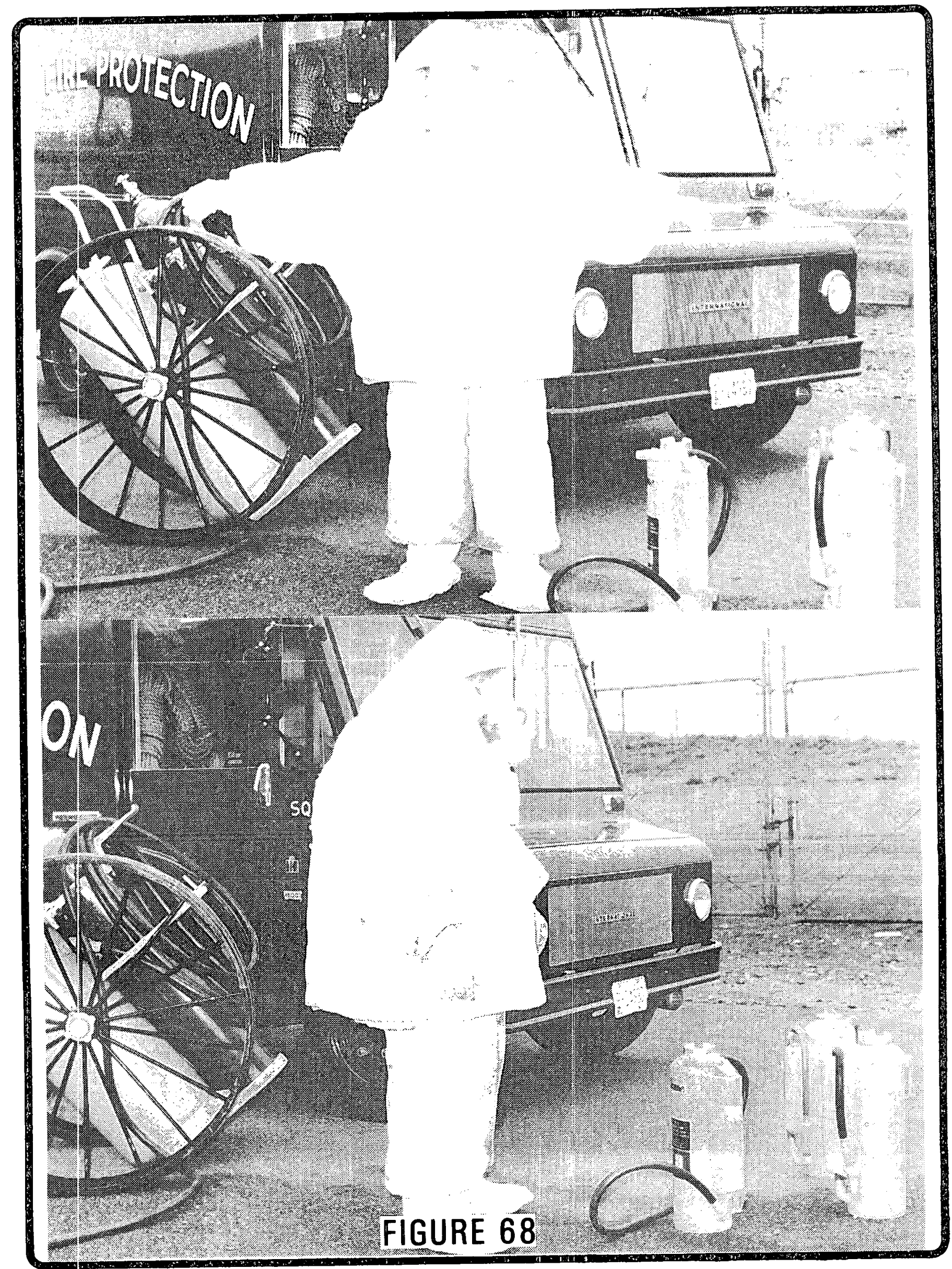




\section{PERSONNEL PROTECTION FROM LIQUID METALS}

ITEMS REQUIRED
1) HEAD COVERING
2) EYE AND FACE PROTECTION
3) HAND PROTECTION
4) PROTECTIVE FOOT W/EAR
5) FIRE-RESISTANT CLOTHING

SAFETY-CLOTHING GUIDE

\begin{tabular}{|c|c|c|c|c|c|}
\hline & $\begin{array}{l}\text { LABORA- } \\
\text { TORY-TYPE } \\
\text { OPERATIONS }\end{array}$ & $\begin{array}{l}\text { INSIDE- } \\
\text { LOOP } \\
\text { SHIELDING }\end{array}$ & $\begin{array}{l}\text { WASHOUT } \\
\text { AND } \\
\text { REPAIRS }\end{array}$ & $\begin{array}{l}\text { FIRE } \\
\text { FIGHTING }\end{array}$ & DISPOSAL \\
\hline $\begin{array}{l}\text { HEAD COVERING } \\
\text { HARD HAT }\end{array}$ & $\mathrm{x}$ & $\mathrm{x}$ & $x$ & $\mathrm{x}$ & $\mathrm{x}$ \\
\hline EYE PROTECTION & & & & & \\
\hline $\begin{array}{l}\text { GOGGLES OR SAFETY } \\
\text { GLASSES } \\
\text { FULL-FACE SHIELD }\end{array}$ & $x$ & $x$ & $x$ & $x$ & $x$ \\
\hline $\begin{array}{l}\text { GLOVES } \\
\text { LEATHER } \\
\text { RUBBER }\end{array}$ & $\begin{array}{l}x \\
x\end{array}$ & $x$ & $\begin{array}{l}x \\
x\end{array}$ & $\mathrm{x}$ & $\mathrm{x}$ \\
\hline FOOT COVERING & \multicolumn{5}{|c|}{ LEATHER REQUIRED, SAFETY TOE OPTIONAL } \\
\hline FIRE-RESISTANT CLOTHIN & $x$ & $x$ & $x$ & $x$ & $x$ \\
\hline
\end{tabular}




\section{FIRST AID}

- BRUSH SODIUM OFF

- SAFETY SHOWER

- WITH CLOTHES ON OR

- STRIPPED TO UNDERWEAR

- DON'T COVER WITH MEDICATION

- SEe a doctor For TREATMENT 


\section{TRANSPORT OF LARGE QUANTITIES OF SODIUM}

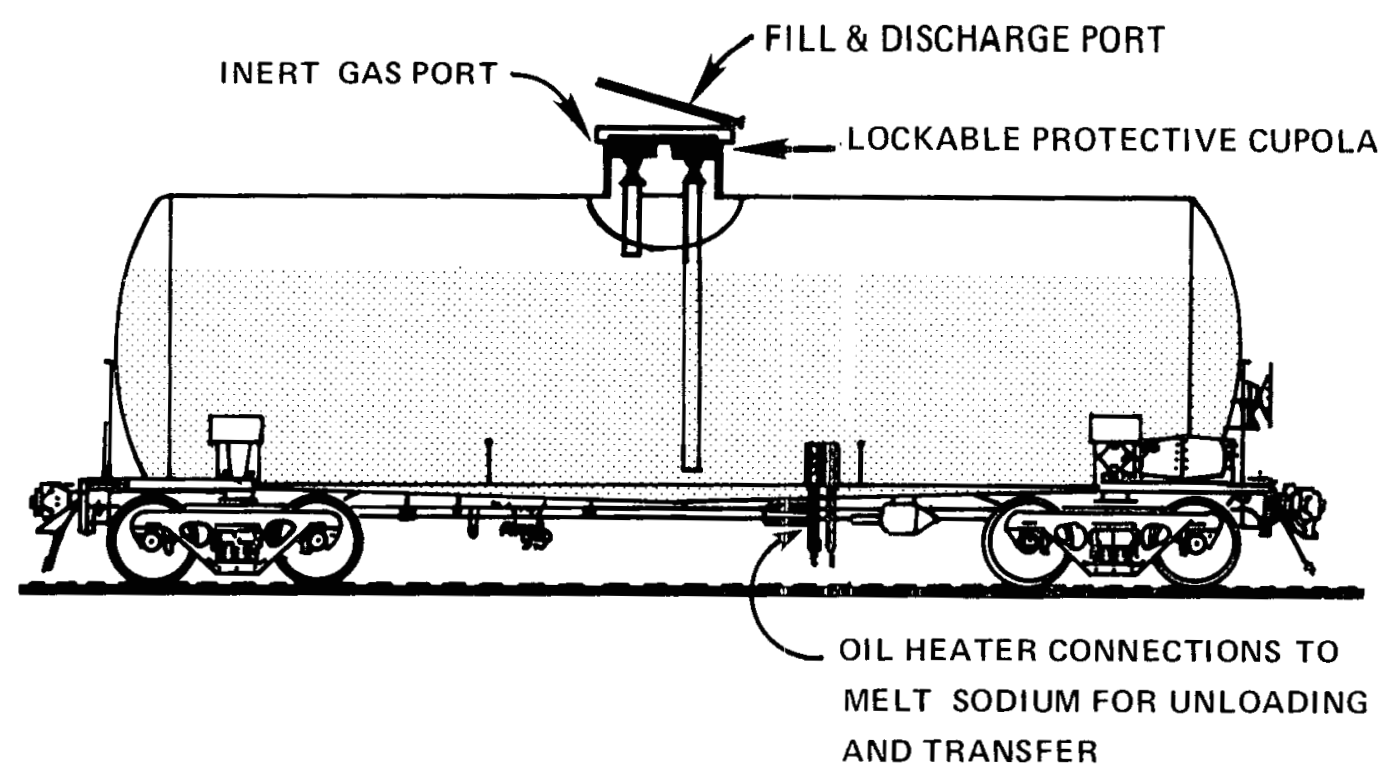

RAILROAD

(105A 300W) TANK CAR

FOR TRANSPORT OF SODIUM

TANK CAPACITY ABOUT 80,000 LBS OR 10,000 GAL. OF SODIUM. GENERALLY LEAVE A HEEL OF 5\% OF TOTAL TO COLLECT ANY SOLIDS. TANKS REQUIRE CLEANING AFTER EACH USE. DEPT. OF TRANSPORTATION TARIFFS SPECIFY TANK CARS TO BE USED ARE APPROVED. 


\section{SUGGESTIONS FOR SODIUM HANDLING}

- cover gas lines in place OF CONNECTED

- SODIUM TRANSFER LINES AND VALVE CONNECTED AND LEAK CHECKED

- TRANSFER LINES AND VESSELS INSULATED

- LOW PRESSURE - 7 to 10 psi (INERT GAS) USED. FOR TRANSFER

- OPERATOR PRESENT

- FIRE PERSONNEL PRESENT ON STANDBY

- RISIDUAL SODIUM IN CONTAINER REMOVED

- SHIPMENT ONLY IN DOT APPROVED CONTAINERS 


\section{BARREL CONTAINER SYSTEM FOR LIOUID METALS}

NOTE:

BARREL CONTAINERS REQUIRE

DEPT. OF TRANSPORTATION SPEC

FOR HAZARDOUS MATERIALS

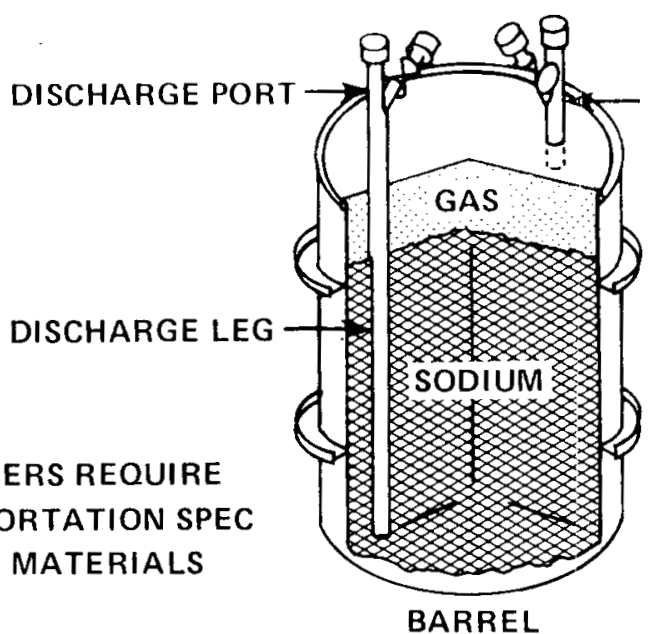

INERT GAS PORT

FOR TRANSFER

(n 5 psig)

SHIPPING CONTAINER

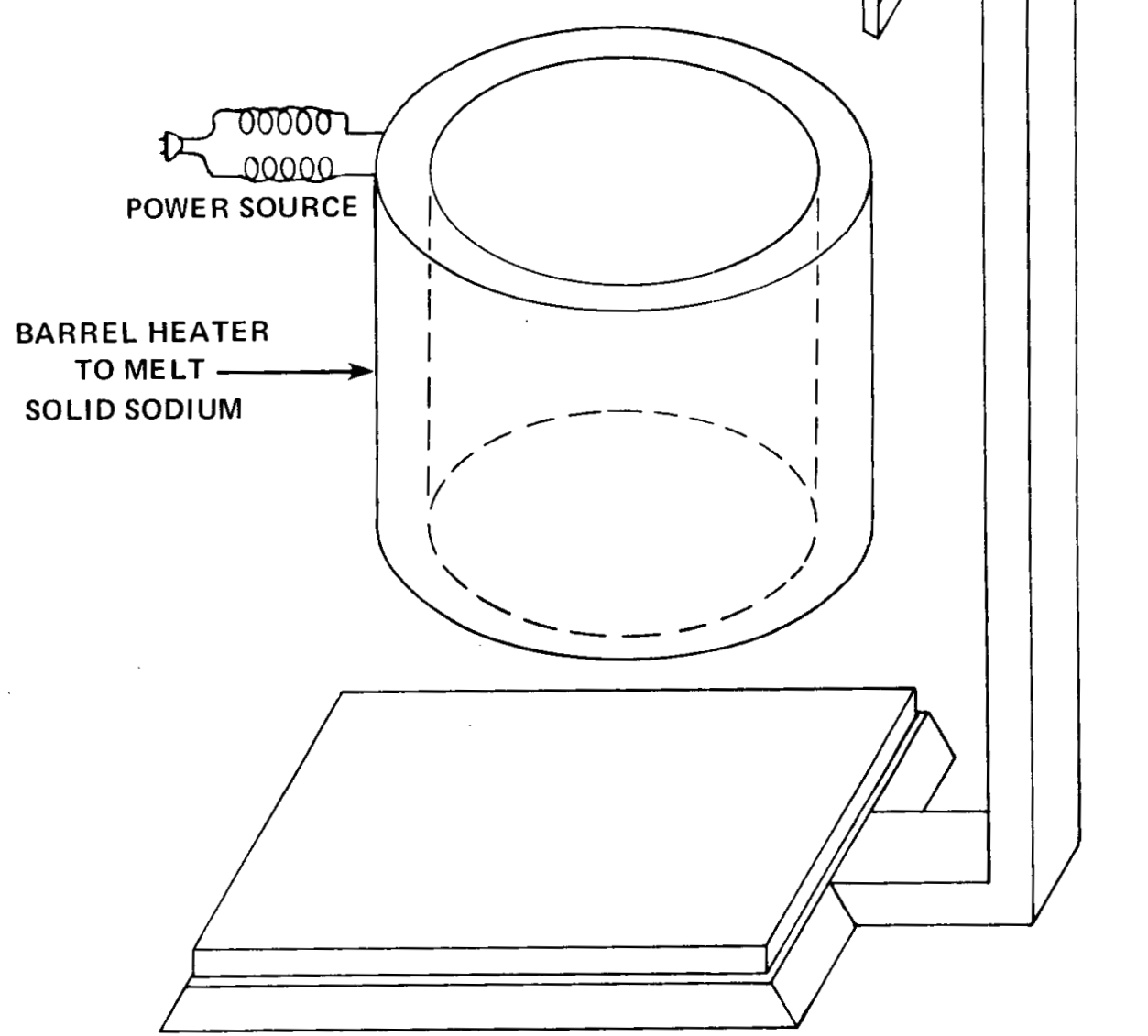

WEIGHING DEVICE FOR DETERMINING QUANTITY

FIGURE 73 


\title{
DISPOSAL OF WASTE SODIUM
}

\author{
- USE metal containers nOt glass \\ - USE $\mathrm{CaCO}_{3}$ LIBERALLY TO COVER \\ - USE APPROVED DISPOSAL AREA \\ - CONTROL REACTION WITH H2O OR BURN \\ - USE COMPLETE PROTECTIVE CLOTHING
}


7.0 EXPERIENCE IN MAJOR REACTORS USING LIQUID METALS 
The reactors that have been constructed are listed in the accompanying table. These range from the SRE and EBR-I to the CRBI which is still on the drawing boards. The salient features of each have been 1 isted to provide ideas as to how reactor designers solve problems of fire control engineering.

In the reactor field, the French have built the largest 1 iquid metal reactors to date and are continuing to enlarge their capacity with the building of the super Phoenix complex. It should be noted that three reactors in use today are pool type machines. These are EBR-II in the U.S., and the Phoenix and the super Phoenix in France. All the remaining reactors of the 1 iquid metal type are loop type reactors. (It will be useful therefore to contrast these machines and note the differences in the approach.) This is seen in Figures 75 and 76 . 


\section{LIQUID METAL REACTORS}

\begin{tabular}{|c|c|c|c|c|c|}
\hline Reactor & Country & $M W_{t}$ & M Ve & $\begin{array}{l}\text { Pool } \\
\text { or } \\
\text { Loop }\end{array}$ & Operation \\
\hline Experimental & & & & & \\
\hline$B R-5$ & Russia & 5 & .. & Loop & 1959 \\
\hline DFR & Great Britain & 72 & 15 & Loop & 1959 \\
\hline EBR-II & United States & 62.5 & 20 & Pool & 1963 \\
\hline FERMI & United States & 200 & 67 & Loop & 1963 \\
\hline RAPSODIE & France & 40 & .. & Loop & 1967 \\
\hline $\mathrm{BR}-60(\mathrm{BOR})$ & Russia & 60 & .. & Loop & 1970 \\
\hline JOYO & Japan & 100 & .. & Loop & 1977 \\
\hline FFTF & United States & 400 & .. & Loop & 1979 \\
\hline $\begin{array}{l}\text { Power } \\
\text { producing }\end{array}$ & & & & & \\
\hline$B N-350$ & Russia & 1000 & 350 & Loop & 1973 \\
\hline PFR & Great Britain & 600 & 250 & Pool & 1973 \\
\hline Phenix & France & 600 & 250 & Pool & 1973 \\
\hline BN-600 & Russia & 1500 & 600 & Pool & 1976 \\
\hline SNR-300 & Debenelux & 730 & 300 & Loop & 1978 \\
\hline MONJU & Japan & 714 & 300 & Loop & 1978 \\
\hline Super Phenix & France & 3000 & 1000 & Pool & 1984 \\
\hline
\end{tabular}

FIGURE 75 


\section{LIQUID METAL REACTOR EXPERIENCE}

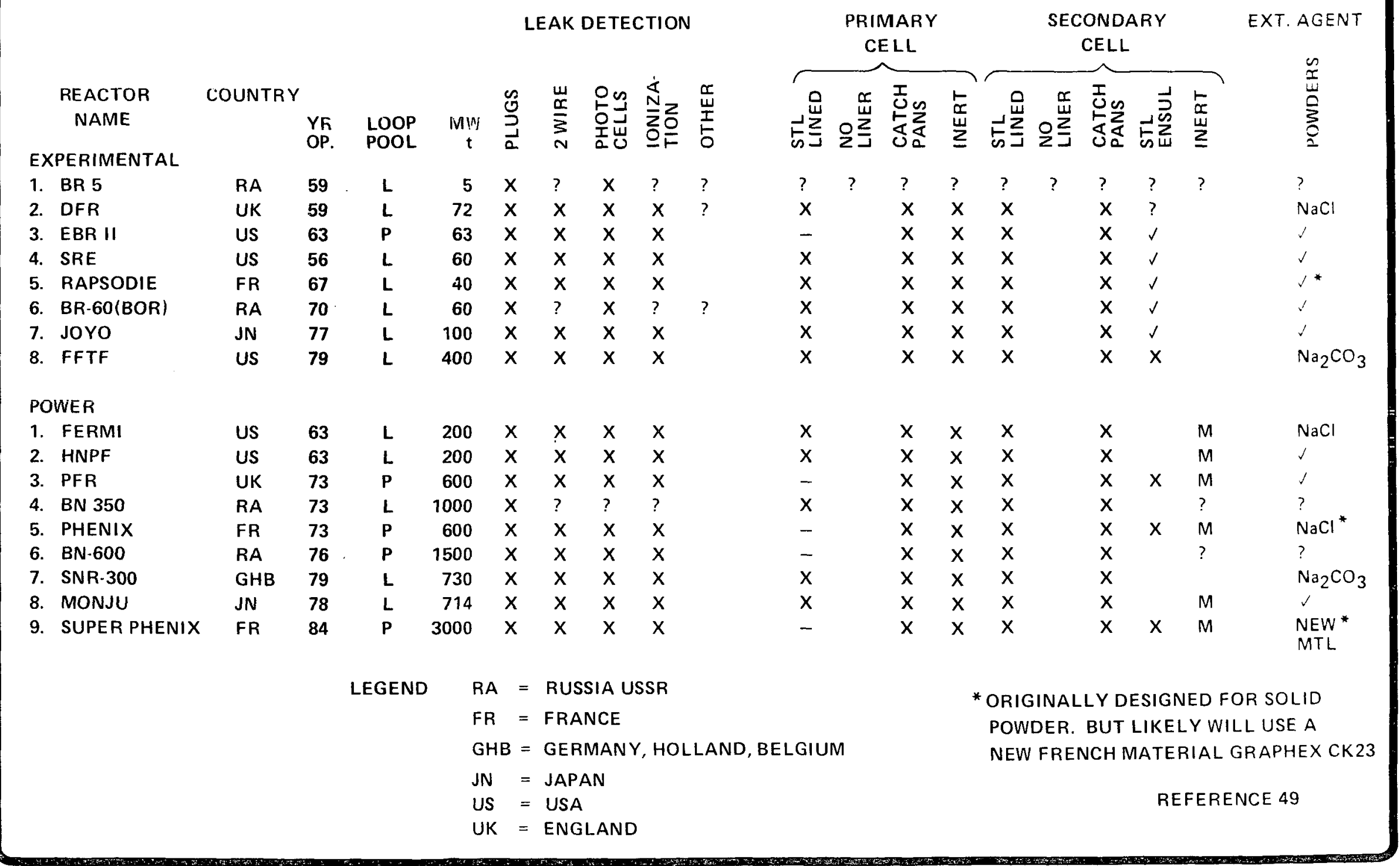




\section{0 BIBLIOGRAPHY}

1. Ballif, J.L. Editor, Sodium Technology, Atomics International, Canoga Park, California, 1970 .

2. Mausteller, J.W., et al, Alkali Metal Handling and Systems operating Techniques, AFC/ANS monograph, Gordon and Breach.

3. Handling Metallic Sodium on a Plant Scale, U.S. Industrial Chemicals Co. Division of National Distillers \& Chemical Corp. N.Y., 1959.

4. Bulmer, G.H., Fire Safety Considerations Related to the Large scale Uses of Sodium, Fourth symposium on Chemical Process Hazards with Special Reference to Plant Design, Manchester, England, April 1971. UKAEA.

5. Fruchard, $Y$. et al, Experimental studies on Sodium Fire Application to Reactors, Conf. Nucl. Europeene, Paris, France, ApriI 1975 .

6. Cooper, D.W. et al, A Critical Review of Sodium Hydroxide Aerosol Toxcity, Harvard School of Public Health, Boston Mass. HS PH/EHS (NUREG) - 880 Dec. 1977.

7. Op cit (1) p. III A-29

8. Op cit (1) p. III $A-30$

9. Yuan, W.W. et al, Bibliography on the Properties of Lithium as a Liquid Metal Coolant, Hanford Engineering Development Laboratory, 1978, HEDL-TME-78-15.

10. Strong, G.W., Techniques in Experimental Physics, 1951, Rhienhold Pub.

11. Generic Requirements for Light Water Nuclear Power Plant Fire Protection, Draft R-2, American Nuclear society, A. NS $-59.4,15$ A ug. 1977.

12. National Fire Codes, National Fire protection Association, Boston, Mass. $197 \overline{6}$.

13. Draft Standard on Fire protection on Liquid Metal Reactors, No. 803-1977 ANSI.

14. Hassburger, J.A., Hilliard, R.A., and Muhlestein, L.D., Sodium Concrete Reaction Tests, June 1974 - HEDL-TME-74-36.

15. Hilliard, R., and Muhlestein, L.D., Sodium Eire protection by Covered Trench - FFTF Proof Tést F4, HEDL-TME-74-36. 
16. Op cit Ref. $1, p$. VI $-A-32$

17. Jarrett, A.A., The Breeder Reactor and the Environment, Public Affairs Seminars, Atomic Industrial For um, Atomics International, 1971 .

18. Op cit Ref. 1 p. III-A-19

19. Op cit Ref. 1 p. III-A-40

20. Op cit Ref. 14, System 26.

21. Op cit Ref. III-A-14

22. Op cit Ref. III-A-12

23. Hilliard, R.K., et al, Sodium Fire Control by space Isolation with Nitrogen Flooding $=$ FFTF Proof Test FHEDL-TME-74-34, June 1974.

24. Jarrett, A.A., The Breeder and the Environment, Public Affairs workshop, Atomic Industrial Forum, Feb. 1971.

25. Fruchard, Y. et al, Experimental Studies on Sodium Fire Application to Reactors, French, U.S. NRC Exchange, April 1975.

26. Morowitz, H.A., et al, U.S. Position Paper Sodium Combustion and its Extinguishment - Techniques and Technology IAEA, International Working Group on Fast Reactors, specialists Meeting; Hanford, Washington; May 1972.

27. Huber, F. et al, verhal ten von Natrium-Branden and Erprobung von Schutzsystem - German Federal RepubIic KNK 1970 .

28. Manufactor's Literataure Carbone Lorraine

29. P. Menzenauer, G. Ochs and W. Peppler, Testing of a Graphite Based Extinguishing Agent For Use on Liquid Metal Fires, KFK 2525, Nov 1977.

30. Op cit Ref. 2 .

31. Op cit Ref. 15 .

32. Bulmer, G.H., The Use of Liquified Nitrogen to Extinguish Sodium Fires, A Possible Technique for a Large Power Reactor, Safe ty and Reliabi ity Directorate, UKA A , Culcheth, O.K. August 1972, SRD-M-43. 
33. Hilliard, R.K. et al, Sodium Fire Control by space Isolation with Nitrogen Flooding - FFTF Proof Test F-2, HFDLTME-74-34.

34. Thomson, J.C., Sodium Fire Extinguishment Tests at DERE, UKAEA, Dounreay, Experimental Reactor Establishement, Thurso, Caithness Scotland, TRG-Memo-4978, July 1969.

35. Cissell, D.W., et al, Guidelines for Sodium Fire Portection, Detection and Conrol, Argonne National Laboratory $\overline{A N} \bar{L}-7691$, June 1970 .

36. Jackson, C.B., Liquid Metals Handbook, Sodium-NAK Supplement U.S. Atomic Emergy Commission \& Dept. of Navy, TID$\overline{5277}$, July 1951 .

37. Nelson, D.B., Guide to Liguid Metals Atomic Power Laboratory U.S. Atomic Energy Commission AECU-1273 March 1951.

38. Mangold, F.L., and Tidball, R.A., Sodium Fires studies, NP-3816 April 1953.

39. AI work. Gracie, J.D. and Droher, J.J., A Study of Sodium Fires, NAA-SR-4383 Atomics International, Canoga Park, California, oct. 1969.

40. Op cit. Ref. 35

41. Morowitz, H.A., et a1, Annual Technical Progress Report LMFBR Safety Programs, AI-AEC-12868 (Health and safety), Atomics International, Canoga Park, CA, oct 1969.

42. Section VII p. VII 3.

43. Op cit Ref. 35 .

44. Op cit Ref. 35

46. Furukawa et al, Experimental Study of Na Loop Fire, PNC-SJ250-69-17 Nov. $19 \overline{69}$.

47. Fruchard, Y., et al, Sodium Fire studies in France, safety Tests and Application on an LMFBR - CEN Cedarache, Dept. of Nuclear Safety - France, CONF. 761001 USAEC - ORNL. 1975.

48. Lane, S.A., Sodium Ionization Leak Detector Final Report, Westinghouse Electric Corporation Nuclear Instrumentation adn Control Div. Hunt Valley, Maryland, WNICP 2381A46, June 1976 .

49. FETF/LMFBR Joint Task Force, Methods for Sodium Leak Detection, Fire prevention and Fire Control, HEDL-TME-71129, Aug. 1971 . 
50. Op cit Ref. 51, Table 1

51. Sauvage, M., and Fruchard, Y., CEA Postion Paper - Sodium Combustion and its Extinguishment, Techniques and Technology, IAEA International Working Group, Fast Reactors Specialist Meeting, Richland, Washington, May 1972, Conference 720579-IAEA-NPR-ORNL.

52. Description of Existing Types of Fire Combustion product Detectors, Prepared by Bechtel Corporation, Exhibit $A$, HEDL-TME-7 $1-129$.

53. Sarma, B.U.B., Hayes F., and Thompson, R.C., Review_of Current Sodium Fire Analytical Methods, GEAP-14148, Sept. 1976 .

54. Stitt, R., et al, Review of Current Sodium Fire Analytical Methods, GEAP-Sept. 1975.

55. Op cit Ref. 1 p. IV $-A-112$

56. Of cit Ref. 32 .

57. Ballif, J.L., operating personnel Training program on Oxygen Deficient Atmospheres, UC-240-002, Ford, Bacon Davis, salt Lake city, utah, sept. 1978. 